Keywords: Plutonium, Neptunium, Uranium, Technetium, Americium, hematite, magnetite, goethite, ferrihydrite, high-level tank waste,

Retention: Permanent

\title{
Literature Review on the Sorption of Plutonium, Uranium, Neptunium, Americium and Technetium to Corrosion Products on Waste Tank Liners
}

Dien Li and Daniel I. Kaplan

February 2012

Savannah River National Laboratory

Savannah River Nuclear Solutions, LLC Aiken, SC 29808

Prepared for the U.S. Department of Energy

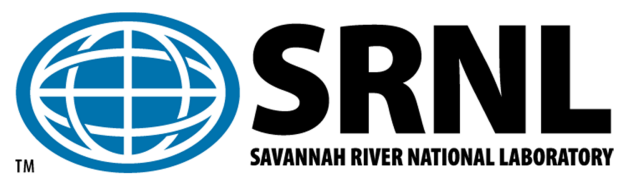
under contract number DE-AC09-08SR22470. 
SRNL-STI-2012-00040

Revision 0

\section{DISCLAIMER}

This work was prepared under an agreement with and funded by the U.S. Government. Neither the U.S. Government or its employees, nor any of its contractors, subcontractors or their employees, makes any express or implied:

1. warranty or assumes any legal liability for the accuracy, completeness, or for the use or results of such use of any information, product, or process disclosed; or

2. representation that such use or results of such use would not infringe privately owned rights; or

3. endorsement or recommendation of any specifically identified commercial product, process, or service.

Any views and opinions of authors expressed in this work do not necessarily state or reflect those of the United States Government, or its contractors, or subcontractors.

\section{Printed in the United States of America}

Prepared for U.S. Department of Energy 


\section{REVIEWS AND APPROVALS}

Dien Li, Co-author, Environmental Sciences

Date

Daniel I. Kaplan, Co-author, Environmental Sciences

Date

Scott H. Reboul, Technical Reviewer, Process Technology Programs

Date

Heather H. Burns, Project Manager, E\&CPT Research Programs

Date

John J. Mayer, Manager, Environmental Sciences

Date

Alice M. Murray, Manager, Environmental Science and Biotechnology

Date

Sharon L. Marra, Manager, E\&CPT Research Programs

Date

Kent H. Rosenberger, SRR, Manager, Closure \& Disposal Assessment

Date 


\section{EXECUTIVE SUMMARY}

The objective of this report was to conduct a literature review to determine whether $\mathrm{Pu}, \mathrm{U}$, $\mathrm{Np}$, Am, and Tc would sorb to corrosion products on tank liners after the tank was filled with reducing grout (cementitious material containing slag to promote reducing conditions). There were no studies in the literature specifically designed to simulate SRS conditions of interest; i.e., sorption of these radionuclides to corrosion products in the presence of reducing grout. One of the key ancillary parameters controlling sorption of these radionuclides is $\mathrm{pH}$; this is especially true of $\mathrm{Pu}$ and $\mathrm{U}$. A grouted tank pore water may have a $\mathrm{pH}>12$ and is expected to maintain that $\mathrm{pH}$ for thousands of years. All literature sorption experiments were performed in $\mathrm{pH}<10.5$ systems. Consequently some extrapolation is involved to predict what would happen in a cementitious - corrosion product environment of $\mathrm{pH}>12$. Furthermore, few studies were found to investigate the radionuclides sorption under reducing conditions. In this document, information is tabulated about trends on how radionuclides sorbed onto corrosion products with respect to ancillary parameters, such as $\mathrm{pH}$, initial radionuclide concentration, and solid phases. Also tabulated are distribution coefficients $\left(\mathrm{K}_{d} \mathrm{~s}\right)$ calculated from the observed sorption fractions and the applicable corrosion product concentrations. Based on the collected information, conclusions were then drawn to determine if conservative assumptions were made in the existing performance assessment (PA) that does not permit $\mathrm{Pu}, \mathrm{U}, \mathrm{Np}, \mathrm{Am}$ and Tc to sorb to corrosion products on tank liners.

It is likely that tank liner corrosion products would significantly sorb $\mathrm{Pu}$. Based on the literature review, $\mathrm{Pu}$ tended to have increased sorption with increasing $\mathrm{pH}$ between $\mathrm{pH} 3$ and 10. At $\mathrm{pH} \mathrm{10,} \mathrm{Pu}$ consists of carbonate and/or hydroxide complexes. It appears that the iron oxyhydroxide solid phases out compete these Pu complexes in an aqueous phase to promote $\mathrm{Pu}$ sorption at a moderate carbonate concentration; however, the carbonate alkalinity of $>100 \mathrm{meq} / \mathrm{L}$ would decrease the $\mathrm{Pu}$ sorption onto goethite $(\alpha-\mathrm{FeOOH})$ (Sanchez et al. 1985).

It is unlikely that tank liner corrosion products would retain much uranyl, $\mathrm{UO}_{2}{ }^{2+}, \mathrm{U}$ in the oxidized state. Unlike $\mathrm{Pu}$-hydroxy/carbonate complexes, it appears that uranyl forms complexes at higher $\mathrm{pH}$ values that are resistant to sorption by $\mathrm{Fe}$-oxyhydroxides. Several studies conducted at $\mathrm{pH} 8$ to 10 demonstrated that uranyl sorption decreased compared to lower $\mathrm{pH}$ systems. However, tank grout will create reducing conditions that will promote the reduction of $\mathrm{UO}_{2}{ }^{2+}$ to $\mathrm{U}(\mathrm{IV})$ and by virtue of its tetra-valence, much greater total $\mathrm{U}$ sorption to corrosion products would be expected under reducing conditions. Information is lacking on how U(IV) would sorb to corrosion products at high $\mathrm{pH}$; this is a specific area where experimental data may be especially useful.

Due to its higher stable oxidation state, it is not surprising that $\mathrm{Np}$ as neptunyl(V) $\left(\mathrm{NpO}_{2}{ }^{+}\right)$sorbs appreciably less than $\mathrm{Pu}(\mathrm{IV})$ to iron oxyhydroxides. As the $\mathrm{pH}$ increased between 5 and 10 the $\mathrm{K}_{\mathrm{d}}$ values of neptunyl increased significantly. Additionally, there was no experimental data to indicate that the $\mathrm{K}_{\mathrm{d}}$ values declined at higher $\mathrm{pH}$ values as was observed with uranyl due to carbonate complexes; however, some modeling work indicated the decreased adsorption of $\mathrm{Np}$ at higher $\mathrm{pH}$ (Wang and Anderko, 2001). Tank 
grout may promote reducing conditions, which may promote reduction of $\mathrm{Np}(\mathrm{V})$ to $\mathrm{Np}$ (IV) and therefore greater sorption to corrosion products. Information is lacking on how $\mathrm{Np}(\mathrm{IV})$ would sorb to corrosion products at high $\mathrm{pH}$ values. Americium sorbs strongly at high $\mathrm{pH}$ values. There was an exceptionally strong $\mathrm{pH}$ dependence, as sorption $\mathrm{K}_{\mathrm{d}}$ values increased from double digits to four or five digits as the $\mathrm{pH}$ increased from 3 to $>8$. Americium is not a redox sensitive element and therefore the $K_{d}$ values would be approximately the same under reducing and older grout that has become oxidized. Pertechnetate, $\mathrm{TcO}_{4}^{-}$, would not be retained by corrosion products due to surface charge repulsion of the Fe-oxyhydroxide at high $\mathrm{pH}$ and high competing anion concentrations. However, under reducing conditions, the $\mathrm{TcO}_{4}{ }^{-}$would readily convert to $\mathrm{Tc}(\mathrm{IV})$ and again, the tetravalent cation, Tc(IV) would be expected to sorb strongly under reducing conditions to the Fe-oxyhydroxides at high $\mathrm{pH}$ values. We are not aware of any $\mathrm{Tc}(\mathrm{IV})$ sorption experiments conducted at elevated $\mathrm{pH}$ values with Fe oxyhydroxides.

The present PA does not address any sorption to corrosion products in its conceptual geochemical model. Based on this literature review, it is a conservative assumption in the present $\mathrm{PA}$ not to include $\mathrm{Pu}, \mathrm{Am}$, and $\mathrm{Np}$ sorption to corrosion products. It is a conservative assumption in the present PA not to include Tc and $\mathrm{U}$ sorption during the period that the tanks are reduced (the first two aging stages), however laboratory information is necessary to confirm this expectation. It is reasonable for the PA to omit $T c$ and $\mathrm{U}$ sorption $\left(\mathrm{K}_{\mathrm{d}}=\sim 0 \mathrm{~mL} / \mathrm{g}\right)$ during oxidizing conditions (older grout). 


\section{TABLE OF CONTENTS}

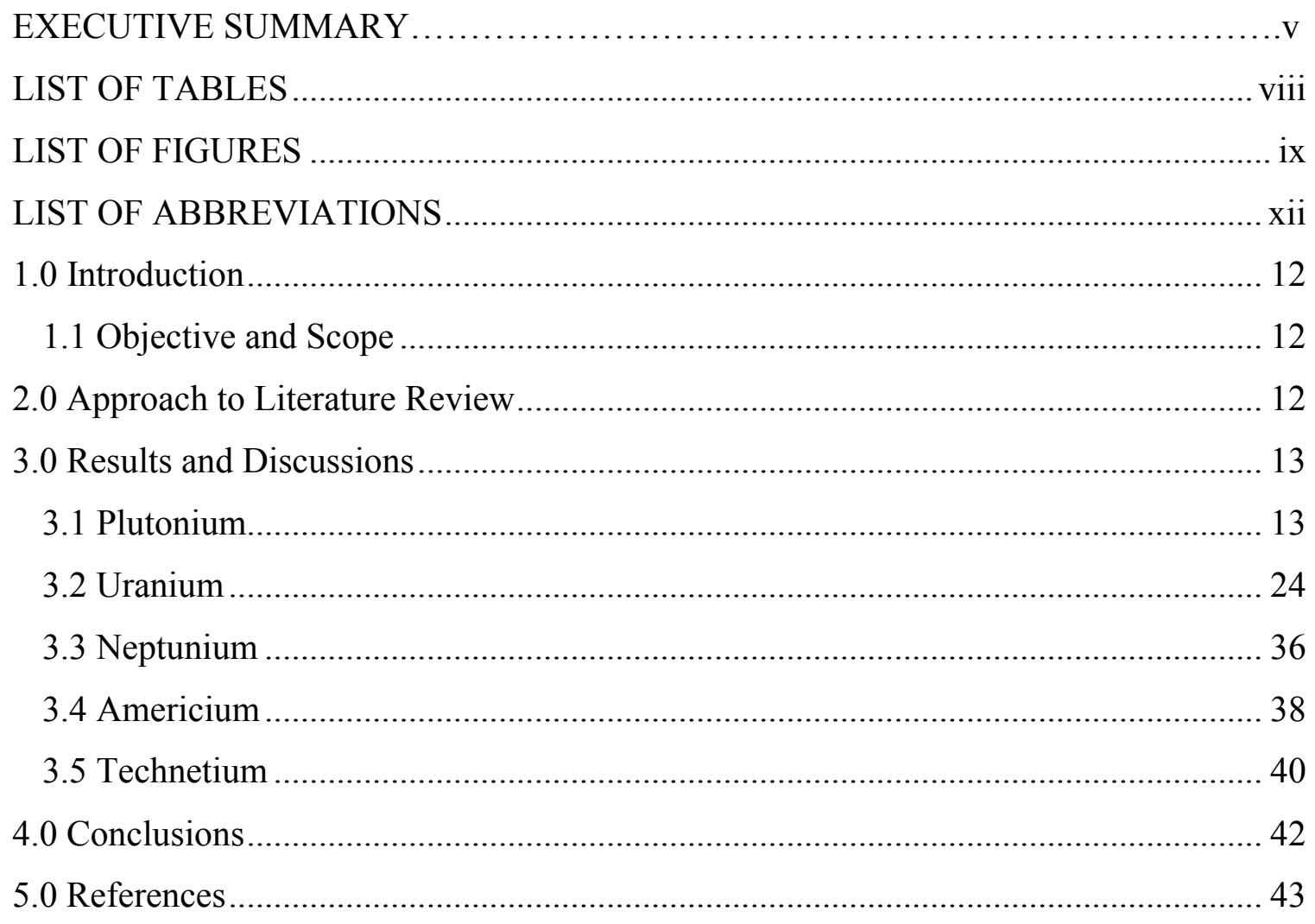




\section{LIST OF TABLES}

Table 1. Plutonium sorption to iron oxyhydroxide phases. .......................................... 15

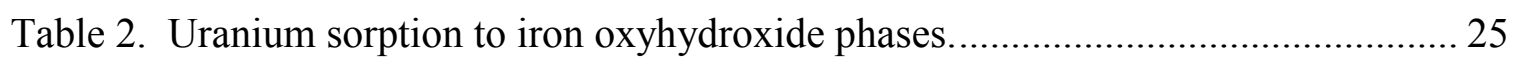

Table 3. Neptunium sorption to iron oxyhydroxide phases....................................... 37

Table 4. Americium sorption to iron oxyhydroxide phases......................................... 39

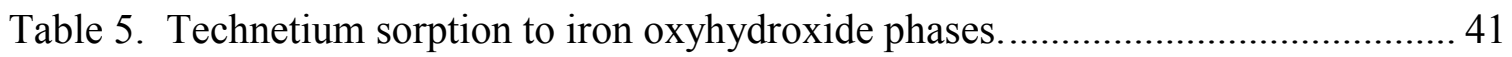


SRNL-STI-2012-00040

Revision 0

\section{LIST OF FIGURES}

Figure 1. The $\mathrm{pH}$ sorption edges of $\mathrm{Pu}(\mathrm{VI})$ and $\mathrm{Pu}(\mathrm{V})$ onto hematite at two different $\mathrm{Pu}$ total concentration (Romanchuk et al. 2011).

Figure 2. Sorption of $\mathrm{Pu}(\mathrm{V})$ on hematite $(\mathrm{A})$, goethite $(\mathrm{B})$ and magnetite $(\mathrm{C})$ at different $\mathrm{pH}$ versus time (Powell et al. 2004, 2005).....................................20

Figure 3. Top) Sorption of $\mathrm{Pu}(\mathrm{IV})$ on goethite as a function of $\mathrm{pH}$ from $0.1 \mathrm{M} \mathrm{NaNO}_{3}$ solution at two plutonium concentrations $\left(1 \times 10^{-11}\right.$ and $\left.1 \times 10^{-10} \mathrm{M}\right)$. Middle) The sorption of $\mathrm{Pu}(\mathrm{V})$ on goethite as a function of $\mathrm{pH}$ from $0.10 \mathrm{M} \mathrm{NaNO}_{3}$ solution at $1 \times 10^{-11} \mathrm{M}$. Bottom) Sorption of $\mathrm{Pu}(\mathrm{V})$ on goethite as a function of $\mathrm{pH}$ from 0.10 $\mathrm{M} \mathrm{NaNO}_{3}$ solution at $1 \times 10^{-10} \mathrm{M}$ (Sanchez et al. 1985).

Figure 4. Top) The effect of carbonate alkalinity on the adsorption of $\mathrm{Pu}(\mathrm{IV})$ on goethite. Bottom) The effect of carbonate alkalinity on the adsorption of $\mathrm{Pu}(\mathrm{V}) \mathrm{pm}$ goethite. Adsorption from natural Soap Lake water is also shown (solid symbols) (Sanchez

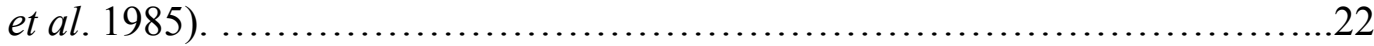

Figure 5. Aqueous speciation of uranium at $\mathrm{I}=0.1 \mathrm{M} \mathrm{NaNO}_{3}$ and $[\mathrm{U}]=4.4 \times 10^{-7} \mathrm{M}$. Major species are shown only (Missana et al. 2003)............................24

Figure 6. Sorption of uranyl versus $\mathrm{pH}$ at $\sum \mathrm{U}=1 \times 10^{-5} \mathrm{M}$ onto $1 \mathrm{~g} / \mathrm{L}$ suspension of ferric hydroxides (left top), goethite (left bottom), synthetic hematite (right upper) and natural hematite (right bottom) in $0.1 \mathrm{M} \mathrm{NaNO}_{3}$ solutions at $25{ }^{\circ} \mathrm{C}$. Symbols denote the experimental data, the solids curves are model calculated assume the given surface parameters and monodendate surface complexes of $\mathrm{UO}_{2} \mathrm{OH}^{+}$and $\left(\mathrm{UO}_{2}\right)_{3}(\mathrm{OH})_{5}{ }^{+}$with $\mathrm{p}^{*} \mathrm{~K}^{\text {ins }}$ values of 8.0 and 15.0 , respectively (Hsi and Langmiur 1985) 30

Figure 7. Cluster used in EXAFS fits for U(VI) sorbed to goethite (Sherman et al. 2008).

Figure 8. Distribution of uranyl-hydroxyl and carbonate complexes versus $\mathrm{pH}$ at $\sum \mathrm{U}=$ $1 \times 10^{-5} \mathrm{M}$, total carbonate $0.01 \mathrm{M}$ in $0.1 \mathrm{M} \mathrm{NaNO}_{3}$ solution at $25{ }^{\circ} \mathrm{C}$ ( Hsi and Langmuir 1985). 31

Figure 9. The fraction of uranyl adsorbed to ferrihydrite as a function of $\mathrm{pH}$ from 2 to 10 in the open systems. All systems are based on $1 \times 10^{-3} \mathrm{M}$ Fe or $0.084 \mathrm{~g} / \mathrm{L}$ ferrihydrite, $\mathrm{P}_{\mathrm{CO} 2}=10^{-3.5}$ bar, and an initial $\mathrm{U}(\mathrm{V})$ concentration of $1 \times 10^{-6} \mathrm{M}$, unless otherwise indicated in the figures. The sorption of $U$ onto ferihydrite with (1) initial U concnetration (left upper), (2) ferrihydrite loading (left bottom), (3) ion strength of $\mathrm{NaNO}_{3}$ (right upper), and (4) $\mathrm{CO}_{2}$ partial pressure (right bottom) (Payne et al. 1998, Payne 1999, Hiemstra et al. 2009). 33 
Figure 10. Structural models for postulated $\equiv \mathrm{Fe}(\mathrm{OH})_{2}\left(\mathrm{UO}_{2}\right)\left(\mathrm{OH}, \mathrm{H}_{2} \mathrm{O}\right)_{4-2 \mathrm{t}}\left(\mathrm{CO}_{3}\right)_{\mathrm{t}}$ complexes on hematite. (A) $\mathrm{t}=1$, (B) $\mathrm{t}=2$, (C) proposed dimeric $\equiv \mathrm{Fe}_{2} \mathrm{O}_{3}\left(\mathrm{UO}_{2}\right)_{2}\left(\mathrm{OH}, \mathrm{H}_{2} \mathrm{O}\right)_{7-2 \mathrm{t}}\left(\mathrm{CO}_{3}\right)_{\mathrm{t}}$ bonded to edge-sharing $\mathrm{FeO}_{6}$ octahedra. To illustrate mismatch between the multimeric complexes and hematite, Fe atoms are shown with the maximum $\mathrm{Fe}-\mathrm{Fe}$ separation found in hematite for neighboring $\mathrm{FeO}_{6}$ octahedra (Bargar et al. 2000). 34

Figure 11. Representation of the most prominent uranyl surface complexes in open systems. (a) Uranyl bound by two singly-coordinated surface group present at a free edge. For this geometry with $\mathrm{d}(\mathrm{Fe}-\mathrm{U})=3.45 \AA$ and $\mathrm{d}\left(\mathrm{U}-\mathrm{O}_{\text {edge }}\right)=2.49 \AA, \mathrm{d}(\mathrm{O}-$ $\mathrm{O})_{\text {edge }}$ is $2.87 \AA$. The outer ligand of the uranyl surface complex in (a) may be $\mathrm{OH}$, $\mathrm{OH}_{2}$, or $\mathrm{CO}_{3}$ (not shown). (b) A uranyl tris-carbonate complex that is singlycoordinated to a $\mathrm{Fe}$ ion in the solid via a carbonate group (Hiemstra et al. 2009, Rossberg et al. 2009). 


\section{LIST OF ABBREVIATIONS}

$\begin{array}{ll}\text { CD } & \text { Charge Distribution } \\ \text { DOE } & \text { Department of Energy } \\ \text { EXAFS } & \text { Extended X-ray Absorption Fine Structure } \\ \text { PA } & \text { Performance Assessment } \\ \text { SRNL } & \text { Savannah River National Laboratory } \\ \text { SRS } & \text { Savannah River Site } \\ \text { XANES } & \text { X-ray Absorption Near-Edge Structure } \\ \text { XAS } & \text { X-ray absorption spectroscopy } \\ \text { XPS } & \text { X-ray photo electron spectroscopy }\end{array}$




\subsection{Introduction}

The Savannah River Site (SRS) has conducted performance assessment (PA) calculations to determine the risk associated with closing liquid waste tanks. The PA estimates the risk associated with a number of scenarios, making various assumptions. Throughout all of these scenarios, it is assumed that the carbon-steel tank liners holding the liquid waste do not sorb the radionuclides. Tank liners have been shown to form corrosion products, such as Fe-oxyhydroxides (Wiersma and Subramanian 2002). Many corrosion products, including Fe-oxyhydroxides, at the high $\mathrm{pH}$ values of tank effluent, take on a very strong negative charge. Given that many radionuclides may have net positive charges, either as free ions or complexed species, it is expected that many radionuclides will sorb to corrosion products associated with tank liners.

\subsection{Objective and Scope}

The objective of this report was to conduct a literature review to investigate whether $\mathrm{Pu}$, $\mathrm{U}, \mathrm{Np}, \mathrm{Am}$ and Tc would sorb to corrosion products on tank liners after they were filled with reducing grout (cementitious material containing slag to promote reducing conditions). The approach was to evaluate radionuclides sorption literature with iron oxyhydroxide phases, such as hematite $\left(\alpha-\mathrm{Fe}_{2} \mathrm{O}_{3}\right)$, magnetite $\left(\mathrm{Fe}_{3} \mathrm{O}_{4}\right)$, goethite $(\alpha$ $\mathrm{FeOOH})$ and ferrihydrite $\left(\mathrm{Fe}_{2} \mathrm{O}_{3} \cdot 0.5 \mathrm{H}_{2} \mathrm{O}\right)$. The primary interest was the sorption behavior under tank closure conditions where the tanks will be filled with reducing cementitious materials. Because there were no laboratory studies conducted using site specific experimental conditions, (e.g., high $\mathrm{pH}$ and HLW tank aqueous and solid phase chemical conditions), it was necessary to extend the literature review to lower $\mathrm{pH}$ studies and noncementitious conditions. Consequently, this report relied on existing lower $\mathrm{pH}$ trends, existing geochemical modeling, and experimental spectroscopic evidence conducted at lower $\mathrm{pH}$ levels. The scope did not include evaluating the appropriateness of $\mathrm{K}_{\mathrm{d}}$ values for the Fe-oxyhydroxides, but instead to evaluate whether it is a conservative assumption to exclude this sorption process of radionuclides onto tank liner corrosion products in the PA model. This may identify another source for PA conservatism since the modeling did not consider any sorption by the tank liner.

\subsection{Approach to Literature Review}

A literature review was conducted with the objectives and scope identified in Section 1.1. The published literature on the sorption of $\mathrm{Pu}, \mathrm{U}, \mathrm{Np}, \mathrm{Am}$ and Tc onto hematite ( $\alpha$ $\left.\mathrm{Fe}_{2} \mathrm{O}_{3}\right)$, magnetite $\left(\mathrm{Fe}_{3} \mathrm{O}_{4}\right)$, goethite $(\alpha-\mathrm{FeOOH})$ and ferrihydrite $\left(\mathrm{Fe}_{2} \mathrm{O}_{3} \cdot 0.5 \mathrm{H}_{2} \mathrm{O}\right)$ was searched, critically reviewed, and studied. Among the key experimental parameters and sorption parameters included in the tables are: radionuclide, spike concentration, $\mathrm{pH}, \mathrm{K}_{\mathrm{d}}$ values, \% sorption, solid phase and its loading, aqueous phase and its ion strength, and comments. The $\mathrm{K}_{\mathrm{d}}$ values and sorption percentages are important because they provide an important metric for comparison between conditions. But perhaps equally important, particularly since extrapolation to higher $\mathrm{pH}$ and tank conditions is necessary, are the comments containing the researcher's (experimentalists) understanding of the sorption 
processes. Although the comments are not quantitative, they provide important insight into sorption mechanisms, the underpinnings for why sorption occurs.

$\mathrm{K}_{\mathrm{d}}$ values and sorption percentages were not always presented in each paper, therefore they had to be calculated using the information provided in the literature. The sorption percent from Powell et al. $(2004,2005)$ are the actual data, but the sorption percent from all other references were estimated based on the published graphs, and the estimated errors for adsorption percentage were within $5 \%$. The sorption coefficient, $\mathrm{K}_{\mathrm{d}}(\mathrm{mL} / \mathrm{g})$, are converted based on the sorption percent, sorbent mass, and solution volume:

$$
\mathrm{K}_{\mathrm{d}}=\frac{(C i-C f)}{C f} \times \frac{V}{M}
$$

or

$$
\mathrm{K}_{\mathrm{d}}=\frac{\% \text { adsorbed }}{\% \text { in solution }} \times \frac{V}{M}
$$

where $\mathrm{C}_{\mathrm{i}}$ and $\mathrm{C}_{\mathrm{f}}$ are initial and final radionuclide concentrations in the solution before and after sorption at the specified equilibrium time, respectively, $V$ is solution volume (mL), and $M$ is sorbent mass (g) (Carbol and Engkvist 1997). In addition, the $\mathrm{K}_{\mathrm{d}}$ data of $\mathrm{Pu}(\mathrm{IV})$ on hematite and goethite from $\mathrm{Lu}$ et al. (1998) are cited directly from this reference and the sorption percentages were converted using equations 1 .

Although a 5\% estimated error in adsorption percentage is reasonable, it can obviously have a major impact on the uncertainty of the $\mathrm{K}_{\mathrm{d}}$ values, especially as the sorption percentages approach 0 or 100 . For example, as the sorption fraction rises from $95 \%$ to $99 \%$, which is compounded by the $\mathrm{V} / \mathrm{M}$ ratio, the associated $\mathrm{K}_{\mathrm{d}}$ rises by five times. Similarly, as the sorption rises from $99.0 \%$ to $99.9 \%$, the $\mathrm{K}_{\mathrm{d}}$ rises by an order of magnitude. For this reason, along with this discussion, the sorption percentages are reported to whole numbers below 100 (i.e., 0-99\%), the near-complete sorption is reported as $\sim 99 \%$, and the $K_{d}$ for near-complete sorption is reported with an "approximation" sign, based on the $\sim 99 \%$ sorption value. The $\mathrm{K}_{\mathrm{d}}$ values are reported up to three digits. However, because of the inherent uncertainties, it must be recognized that not all of the three digits are significant. It is also noted that some of the references identified the quantities of Fe-oxyhydroxides in units of $\mathrm{m}^{2} / \mathrm{L}$ (e.g., Powell et al. 2004, 2005, Sanchez et al. 1985) or in M (e.g., Girvin et al. 1991, Hiemstra et al. 2009, Payne et al. 1998, Waite et al. 1994), which were converted to units of $\mathrm{g} / \mathrm{L}$ for use in calculating the $\mathrm{K}_{\mathrm{d}} \mathrm{S}$. In some cases, the assumptions made to support the unit conversions may have contributed additional uncertainty to the $\mathrm{K}_{\mathrm{d}}$ values.

\subsection{Results and Discussions}

\subsection{Plutonium}

A summary of the plutonium sorption information (adsorption coefficient $\mathrm{K}_{\mathrm{d}}$, adsorption percentage, initial $\mathrm{Pu}$ concentration, $\mathrm{pH}$, ion strength, equilibrium time, and sorbent loading) to iron oxyhydroxide phases is given in Table 1. 
Romanchuk et al. (2011) studied Pu sorption onto hematite colloids $\left(11 \mathrm{~m}^{2} / \mathrm{L}\right)$ at $10^{-14} \mathrm{M}$ and $10^{-9} \mathrm{M} \mathrm{Pu}$ concentrations over the $\mathrm{pH}$ range 1-7. In this study, a wide range of $\mathrm{Pu}$ concentrations and two $\mathrm{Pu}$ isotopes were used. ${ }^{237} \mathrm{Pu}$ and ${ }^{239} \mathrm{Pu}$ was $\mathrm{Pu}(\mathrm{IV})$ in $2 \mathrm{M} \mathrm{HNO}_{3}$ stock solution; to prepare $\mathrm{Pu}(\mathrm{VI})$, small amount of $\mathrm{NaBrO}_{3}$ was added for oxidation. Figure 1 shows that for both $\mathrm{Pu}(\mathrm{VI})$ and $\mathrm{Pu}(\mathrm{IV}),<10 \% \mathrm{Pu}$ sorption was observed at $\mathrm{pH}<$ 3 , the $\mathrm{Pu}$ sorption increases with $\mathrm{pH}$ and the $\mathrm{Pu}$ species are completely up-taken by hematite at $\mathrm{pH}>5.5$. Pu sorption, regardless of oxidation state, reaches equilibrium faster in solutions containing $10^{-14} \mathrm{M}$ Pu than that containing $10^{-9} \mathrm{M} \mathrm{Pu}$ (10 days versus 25 days, respectively). At both $\mathrm{Pu}$ concentrations, the similarity of the sorption edges for $\mathrm{Pu}(\mathrm{IV})$ and $\mathrm{Pu}(\mathrm{VI})$ at steady-state indicates the reduction of $\mathrm{Pu}(\mathrm{VI})$. Solvent extraction results confirmed that $\mathrm{Pu}(\mathrm{IV})$ is associated with hematite colloids above $\mathrm{pH}$ 5. The authors did not know what caused Pu redox transformations upon contact with hematite, but offered the following potential explanations: $\mathrm{Pu}$ redox transformations were due to (1) tracer amount of $\mathrm{Fe}(\mathrm{II})$ on hematite surface, (2) disproportionation of $\mathrm{Pu}(\mathrm{V})$, (3) electron shuttling from semiconducting hematite surface, or (4) self-reduction. The rate limiting step in $\mathrm{Pu}(\mathrm{VI})$ sorption is its surface-mediated reduction; the polymerization of $\mathrm{Pu}(\mathrm{IV})$ occurred on hematite surface.
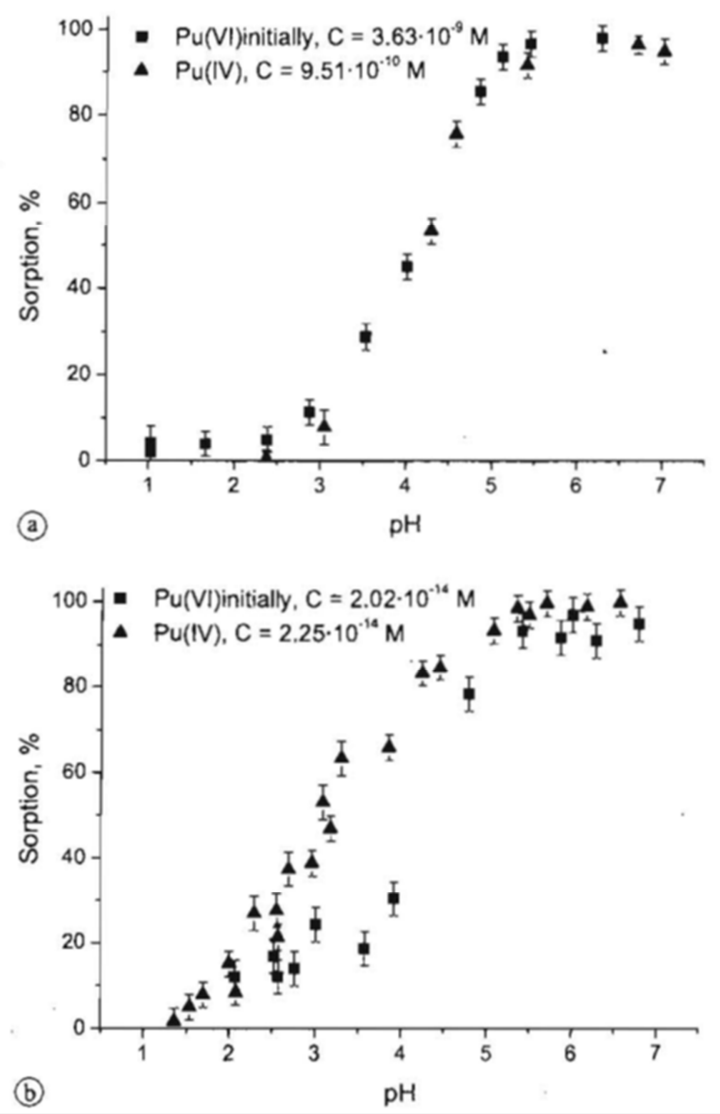

Figure 1. The $\mathrm{pH}$ sorption edges of $\mathrm{Pu}(\mathrm{VI})$ and $\mathrm{Pu}(\mathrm{IV})$ onto hematite at two different $\mathrm{Pu}$ total concentrations (Romanchuk et al. 2011). 
Table 1. Plutonium sorption to iron oxyhydroxide phases

\begin{tabular}{|c|c|c|c|c|c|c|c|c|}
\hline $\begin{array}{l}\text { Radio- } \\
\text { nuclide }\end{array}$ & Sorbents & Solution & $\begin{array}{l}\text { Ion } \\
\text { strength }\end{array}$ & pH & $\begin{array}{l}\mathbf{K}_{\mathrm{d}} \\
(\mathrm{mL} / \mathrm{g})\end{array}$ & $\begin{array}{l}\text { Sorp- } \\
\text { tion } \\
(\%)\end{array}$ & $\begin{array}{l}\text { Equil } \\
\text { time } \\
\text { (hrs) }\end{array}$ & $\begin{array}{l}\text { Reference / } \\
\text { Description }\end{array}$ \\
\hline \multirow[t]{12}{*}{$\mathrm{Pu}$} & \multirow{6}{*}{$\begin{array}{l}\text { Hematite } \\
\text { BET } 35 \\
\mathrm{~m}^{2} / \mathrm{g} \\
0.32 \mathrm{~g} / \mathrm{L} \\
\text { or } \\
11 \mathrm{~m}^{2} / \mathrm{L}\end{array}$} & \multirow{3}{*}{$\begin{array}{l}\mathrm{Pu}(\mathrm{VI}) \\
3.63 \times 10^{-9} \\
\mathrm{M}\end{array}$} & \multirow{3}{*}{$\begin{array}{l}0.1 \mathrm{M} \\
\mathrm{NaClO}_{4}\end{array}$} & 2.8 & 386 & 11 & \multirow[t]{6}{*}{600} & \multirow{12}{*}{$\begin{array}{l}\text { The authors attribute } \\
\text { Pu redox } \\
\text { transformation } \\
\text { occurred upon } \\
\text { sorption due to (1) } \\
\text { tracer amount of Fe(II) } \\
\text { on hematite surface, } \\
\text { (2) disproportionation } \\
\text { of Pu(V), (3) electron } \\
\text { shuttling from semi- } \\
\text { conducting hematite } \\
\text { surface, or (4) self- } \\
\text { reduction. } \\
\text { The rate limiting step } \\
\text { in Pu(VI) sorption is } \\
\text { its surface-mediated } \\
\text { reduction; the } \\
\text { polymerization of } \\
\text { Pu(IV) occurred on } \\
\text { hematite surface. The } \\
\mathrm{K}_{\mathrm{d}} \text { increases from } \mathrm{pH} \\
2.8 \text { to } 7.0 \text {; above } \mathrm{pH} \\
6 \text {, the } \mathrm{K}_{\mathrm{d}} \text { was }>30,000 \\
\mathrm{~mL} / \mathrm{g} \text {. }\end{array}$} \\
\hline & & & & 5.5 & $5.93 \times 10^{4}$ & 95 & & \\
\hline & & & & 6.3 & $1.01 \times 10^{5}$ & 97 & & \\
\hline & & $\mathrm{Pu}(\mathrm{IV})$ & $0.1 \mathrm{M}$ & 3.1 & 271 & 8 & & \\
\hline & & $\begin{array}{l}9.51 \times 10^{-} \\
{ }^{10} \mathrm{M}\end{array}$ & $\mathrm{NaClO}_{4}$ & 5.5 & $3.59 \times 10^{4}$ & 92 & & \\
\hline & & & & 7.0 & $5.94 \times 10^{4}$ & 95 & & \\
\hline & \multirow{6}{*}{$\begin{array}{l}\text { Hematite } \\
\text { BET 35 } \\
\mathrm{m}^{2} / \mathrm{g} \\
0.32 \mathrm{~g} / \mathrm{L} \\
\text { or } \\
11 \mathrm{~m}^{2} / \mathrm{L}\end{array}$} & \multirow{3}{*}{$\begin{array}{l}\mathrm{Pu}(\mathrm{VI}) \\
2.02 \times 10^{-} \\
{ }^{14} \mathrm{M}\end{array}$} & \multirow{3}{*}{$\begin{array}{l}0.1 \mathrm{M} \\
\mathrm{NaClO}_{4}\end{array}$} & 3.0 & 987 & 24 & \multirow[t]{6}{*}{240} & \\
\hline & & & & 4.8 & $1.11 \times 10^{4}$ & 78 & & \\
\hline & & & & 6.7 & $4.15 \times 10^{4}$ & 93 & & \\
\hline & & \multirow{3}{*}{\begin{tabular}{|l|}
$\mathrm{Pu}(\mathrm{IV})$ \\
$2.25 \times 10^{-}$ \\
${ }^{14} \mathrm{M}$
\end{tabular}} & \multirow{3}{*}{$\begin{array}{l}0.1 \mathrm{M} \\
\mathrm{NaClO}_{4}\end{array}$} & 3.0 & $2.0 \times 10^{3}$ & 39 & & \\
\hline & & & & 5.1 & $4.15 \times 10^{4}$ & 93 & & \\
\hline & & & & 6.6 & $3.09 \times 10^{5}$ & 99 & & \\
\hline \multirow[t]{7}{*}{$\mathrm{Pu}$} & \multirow{4}{*}{$\begin{array}{l}\text { Hematite } \\
\text { BET } 36.3 \\
\mathrm{~m}^{2} / \mathrm{g} \\
0.276 \mathrm{~g} / \mathrm{L} \\
\text { or } 10 \\
\mathrm{~m}^{2} / \mathrm{L}\end{array}$} & $\begin{array}{l}\mathrm{Pu}(\mathrm{V}) \\
1.5 \times 10^{-8} \\
\mathrm{M}\end{array}$ & $\begin{array}{l}0.01 \mathrm{M} \\
\mathrm{NaCl}\end{array}$ & 3 & 36 & 1 & 97 & \multirow{7}{*}{$\begin{array}{l}\text { Powell et al. (2005) } \\
\text { This is primarily a } \\
\text { study of kinetics of } \\
\text { oxidation state } \\
\text { transformations and } \\
\text { Pu sorption from the } \\
\text { aqueous phase in the } \\
\text { presence of iron } \\
\text { oxides. At pH } 3 \text {, little } \\
\text { sorption and reduction } \\
\text { of } \mathrm{Pu}(\mathrm{V}) \text { was observed }\end{array}$} \\
\hline & & & & 5 & $6.17 \times 10^{3}$ & 63 & 118 & \\
\hline & & & & 6.5 & $1.77 \times 10^{4}$ & 83 & 73 & \\
\hline & & & & 8 & $1.17 \times 10^{5}$ & 97 & 97 & \\
\hline & $\begin{array}{l}1.38 \mathrm{~g} / \mathrm{L} \\
50 \mathrm{~m}^{2} / \mathrm{L} \\
\end{array}$ & & & 8 & $7.19 \times 10^{4}$ & 99 & 2 & \\
\hline & \multirow{2}{*}{$\begin{array}{l}2.76 \mathrm{~g} / \mathrm{L} \\
\text { or } 100 \\
\mathrm{~m}^{2} / \mathrm{L}\end{array}$} & & & 3 & 7 & 2 & 355 & \\
\hline & & & & 8 & $\sim 3.58 \times 10^{4}$ & $\sim 99$ & 3 & \\
\hline
\end{tabular}




\begin{tabular}{|c|c|c|c|c|c|c|c|c|}
\hline $\begin{array}{l}\text { Radio- } \\
\text { nuclide }\end{array}$ & Sorbents & Solution & $\begin{array}{l}\text { Ion } \\
\text { strength }\end{array}$ & pH & $\begin{array}{l}K_{d} \\
(m L / g)\end{array}$ & $\begin{array}{l}\text { Sorp- } \\
\text { tion } \\
(\%)\end{array}$ & $\begin{array}{l}\text { Equil } \\
\text { time } \\
\text { (hrs) }\end{array}$ & $\begin{array}{l}\text { Reference / } \\
\text { Description }\end{array}$ \\
\hline & & & & & & & & \multirow{9}{*}{$\begin{array}{l}\text { on either hematite or } \\
\text { goethite. At pH 5-8, } \\
\text { the overall removal of } \\
\mathrm{Pu}(\mathrm{V}) \text { was found to be } \\
\text { approximately second } \\
\text { order with respect to } \\
\text { hematite } \\
\text { concentration. In } \\
\text { contrast to hematite, } \\
\mathrm{Pu}(\mathrm{V}) \text { sorption to } \\
\text { goethite occurred } \\
\text { rapidly relative to } \\
\text { reduction. }\end{array}$} \\
\hline \multirow[t]{8}{*}{$\mathrm{Pu}$} & $\begin{array}{l}\text { Goethite } \\
\text { BET }\end{array}$ & \multirow{8}{*}{$\begin{array}{l}\mathrm{Pu}(\mathrm{V}) \\
1.5 \times 10^{-8} \\
\mathrm{M}\end{array}$} & \multirow[t]{8}{*}{$\begin{array}{l}0.01 \mathrm{M} \\
\mathrm{NaCl}\end{array}$} & 6.5 & $2.0 \times 10^{5}$ & 96 & 23 & \\
\hline & $\begin{array}{l}167.2 \\
\mathrm{~m}^{2} / \mathrm{g} \\
0.12 \mathrm{~g} / \mathrm{L} \\
\text { or } \\
20 \mathrm{~m}^{2} / \mathrm{L}\end{array}$ & & & 8 & $\sim 8.25 \times 10^{5}$ & $\sim 99$ & 24 & \\
\hline & \multirow{2}{*}{$\begin{array}{l}\text { Goethite } \\
0.30 \mathrm{~g} / \mathrm{L} \\
\text { or } 50 \\
\mathrm{~m}^{2} / \mathrm{L}\end{array}$} & & & 3 & 68 & 2 & 315 & \\
\hline & & & & 8 & $3.3 \times 10^{5}$ & 99 & 25 & \\
\hline & \multirow{3}{*}{$\begin{array}{l}\text { Goethite } \\
0.60 \mathrm{~g} / \mathrm{L} \\
\text { or } \\
100 \mathrm{~m}^{2} / \mathrm{L}\end{array}$} & & & 5 & $8.14 \times 10^{3}$ & 83 & 25 & \\
\hline & & & & 6.5 & $5.39 \times 10^{4}$ & 97 & 24 & \\
\hline & & & & 8 & $\sim 1.65 \times 10^{5}$ & $\sim 99$ & 3 & \\
\hline & $\begin{array}{l}\text { Goethite } \\
2.99 \mathrm{~g} / \mathrm{L} \\
\text { or } \\
500 \mathrm{~m}^{2} / \mathrm{L}\end{array}$ & & & 6.5 & $\sim 3.31 \times 10^{4}$ & $\sim 99$ & 24 & \\
\hline \multirow[t]{6}{*}{$\mathrm{Pu}$} & Magnetite & \multirow{6}{*}{$\begin{array}{l}\mathrm{Pu}(\mathrm{V}) \\
1.5 \times 10^{-8} \\
\mathrm{M}\end{array}$} & \multirow{6}{*}{$\begin{array}{l}0.01 \mathrm{M} \\
\mathrm{NaCl}\end{array}$} & 3 & 525 & 17 & 438 & \multirow{6}{*}{$\begin{array}{l}\text { Powell et al. (2004) } \\
\text { In the pH range of 5-8, } \\
\text { sorption is rate- } \\
\text { limiting step, and } \\
\text { reduction is mediated } \\
\text { by solid phase; at } \mathrm{pH} \\
3 \text {, reduction occurs in } \\
\text { the aqueous phase. As } \\
\text { pH values increased } \\
\text { from pH } 3 \text { to } 8 \text {, the } \mathrm{K}_{\mathrm{d}} \\
\text { values increased; at } \\
\text { pH } 8 \text { the } \mathrm{K}_{\mathrm{d}} \text { values } \\
\text { were }(+\infty)(>300,000 \\
\mathrm{mL} / \mathrm{g}) .\end{array}$} \\
\hline & $\begin{array}{l}\text { BET } 25.4 \\
\mathrm{~m}^{2} / \mathrm{g}\end{array}$ & & & 5 & $2.95 \times 10^{4}$ & 92 & 22 & \\
\hline & $\begin{array}{l}0.39 \mathrm{~g} / \mathrm{L} \\
\text { or } \\
10 \mathrm{~m}^{2} / \mathrm{L} \\
\end{array}$ & & & 8 & $\sim 2.54 \times 10^{5}$ & $\sim 99$ & 24 & \\
\hline & \multirow{3}{*}{$\begin{array}{l}\text { Magnetite } \\
3.94 \mathrm{~g} / \mathrm{L} \\
\text { or } 100 \\
\mathrm{~m}^{2} / \mathrm{L}\end{array}$} & & & 3 & 56 & 18 & 26 & \\
\hline & & & & 3 & $2.57 \times 10^{3}$ & 91 & 215 & \\
\hline & & & & 8 & $\sim 2.54 \times 10^{4}$ & $\sim 99$ & 2 & \\
\hline \multirow[t]{8}{*}{$\mathrm{Pu}$} & \multirow{4}{*}{$\begin{array}{l}\text { Goethite } \\
\text { BET } 51.8 \\
\mathrm{~m}^{2} / \mathrm{g} \\
0.55 \mathrm{~g} / \mathrm{L} \\
\text { or } \\
28.5 \mathrm{~m}^{2} / \mathrm{L}\end{array}$} & \multirow{4}{*}{$\begin{array}{l}\mathrm{Pu}(\mathrm{IV}) \\
1 \times 10^{-11} \\
\mathrm{M}\end{array}$} & \multirow{4}{*}{$\begin{array}{l}0.1 \mathrm{M} \\
\mathrm{NaNO}_{3}\end{array}$} & 2.6 & 979 & 35 & \multirow[t]{4}{*}{24} & \multirow{8}{*}{$\begin{array}{l}\text { Sanchez et al. (1985) } \\
\text { Ion strength increase } \\
\text { does not influence } \\
\mathrm{Pu}(\mathrm{IV}) \text { or } \mathrm{Pu}(\mathrm{V}) \\
\text { sorption. In the } \\
\text { presence of DOC, } \\
\mathrm{Pu}(\mathrm{V}) \text { reduction } \\
\text { occurred in solution; } \\
\mathrm{Pu}(\mathrm{IV}) \text { sorption on } \\
\text { goethite decrease. } \\
\text { Increasing total } \\
\text { alkalinity above } 100 \\
\text { meq/L promoted }\end{array}$} \\
\hline & & & & 4 & $7.27 \times 10^{3}$ & 80 & & \\
\hline & & & & 6.2 & $3.46 \times 10^{4}$ & 95 & & \\
\hline & & & & 9.0 & $\sim 1.8 \times 10^{5}$ & $\sim 99$ & & \\
\hline & \multirow{3}{*}{$\begin{array}{l}\text { Goethite } \\
\text { BET } 51.8 \\
\mathrm{~m}^{2} / \mathrm{g} \\
0.55 \mathrm{~g} / \mathrm{L} \\
\text { or } 28.5 \\
\mathrm{~m}^{2} / \mathrm{L}\end{array}$} & \multirow{3}{*}{$\begin{array}{l}\mathrm{Pu}(\mathrm{IV}) \\
1 \times 10^{-10} \\
\mathrm{M}\end{array}$} & \multirow{3}{*}{$\begin{array}{l}0.1 \mathrm{M} \\
\mathrm{NaNO}_{3}\end{array}$} & 2.3 & 202 & 10 & \multirow[t]{3}{*}{24} & \\
\hline & & & & 3.7 & $1.82 \times 10^{3}$ & 50 & & \\
\hline & & & & 6.2 & $2.85 \times 10^{4}$ & 94 & & \\
\hline & Goethite & $\mathrm{Pu}(\mathrm{V})$ & $0.1 \mathrm{M}$ & 4 & 18 & 1 & 1 & \\
\hline
\end{tabular}


SRNL-STI-2012-00040

Revision 0

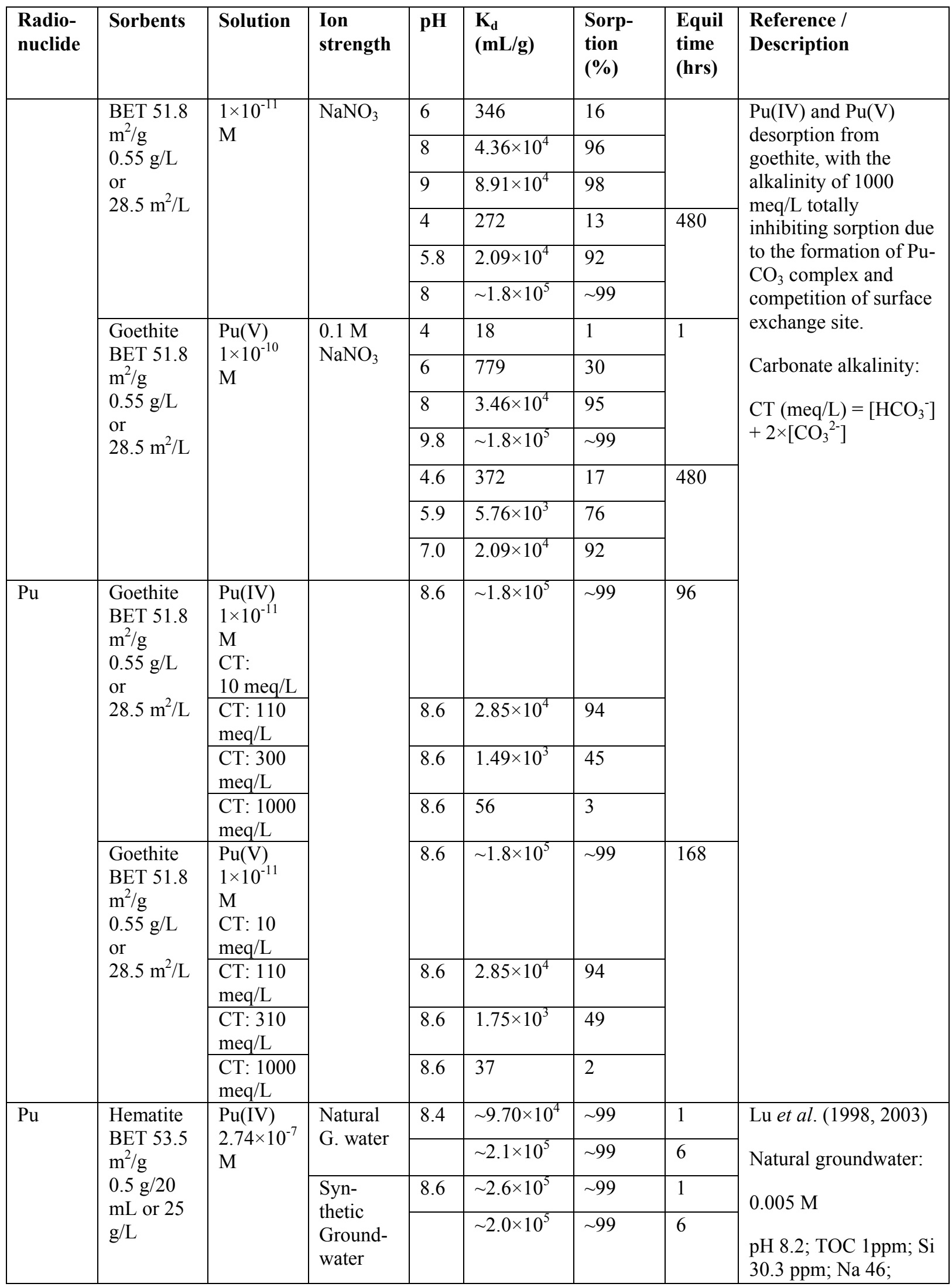




\begin{tabular}{|c|c|c|c|c|c|c|c|c|}
\hline $\begin{array}{l}\text { Radio- } \\
\text { nuclide }\end{array}$ & Sorbents & Solution & $\begin{array}{l}\text { Ion } \\
\text { strength }\end{array}$ & pH & $\begin{array}{l}\mathbf{K}_{\mathrm{d}} \\
(\mathrm{mL} / \mathrm{g})\end{array}$ & $\begin{array}{l}\text { Sorp- } \\
\text { tion } \\
(\%)\end{array}$ & $\begin{array}{l}\text { Equil } \\
\text { time } \\
\text { (hrs) }\end{array}$ & $\begin{array}{l}\text { Reference / } \\
\text { Description }\end{array}$ \\
\hline & & \multirow{4}{*}{$\begin{array}{l}\mathrm{Pu}(\mathrm{V}) \\
2.74 \times 10^{-7} \\
\mathrm{M}\end{array}$} & \multirow{2}{*}{$\begin{array}{l}\text { Natural } \\
\text { Ground- } \\
\text { water }\end{array}$} & 8.4 & 49 & 55 & 1 & \multirow{12}{*}{$\begin{array}{l}\text { ppm; Ca } 13.3 \text { ppm; } \\
\text { Mg } 1.9 \text { ppm; K } 5.4 \\
\text { ppm } \\
\text { Aqueous carbonate did } \\
\text { not influence the } \\
\text { sorption of } \mathrm{Pu} \text {. } \\
\text { Increasing pH from } \\
5.05 \text { to } 8.44 \text { increased } \\
\mathrm{Pu}(\mathrm{V}) \text { and had no } \\
\text { significant effect on } \\
\mathrm{Pu}(\mathrm{IV}) \text { sorption. } \\
\mathrm{Contact} \text { time }(1,24 \text {, } \\
\text { and } 96 \mathrm{hr}) \text { influenced } \\
\mathrm{Pu}(\mathrm{V}) \text { sorption, but } \\
\text { not Pu(IV) sorption. } \\
\text { Synthetic } \\
\text { groundwater: } 0.005 \mathrm{M} \\
\text { Na } \mathrm{CO}_{3} / \mathrm{NaHCO} \\
\\
\text { The } \mathrm{K}_{\mathrm{d}} \text { for Pu(IV) } \\
\text { were from its Table } 4 \text {; } \\
\text { while the } \mathrm{K}_{\mathrm{d}} \text { for } \mathrm{Pu}(\mathrm{V}) \\
\text { from its Figure } 2 \& 3 \text {. } \\
\text { There are } \\
\text { discrepancies in Table } \\
2 \text { and Figure } 2 \text { and } 3 \\
\text { in the original report. }\end{array}$} \\
\hline & & & & & 93 & 70 & 96 & \\
\hline & & & \multirow{2}{*}{$\begin{array}{l}\text { Syn- } \\
\text { thetic } \\
\text { Ground- } \\
\text { water }\end{array}$} & 8.6 & 460 & 92 & 1 & \\
\hline & & & & & $\sim 3.96 \times 10^{3}$ & $\sim 99$ & 6 & \\
\hline & \multirow{8}{*}{$\begin{array}{l}\text { Goethite } \\
\text { BET } 68 \\
\mathrm{~m}^{2} / \mathrm{g} \\
0.5 \mathrm{~g} / 20 \\
\mathrm{~mL} \text { or } 25 \\
\mathrm{~g} / \mathrm{L}\end{array}$} & \multirow{4}{*}{$\begin{array}{l}\mathrm{Pu}(\mathrm{IV}) \\
2.74 \times 10^{-7} \\
\mathrm{M}\end{array}$} & \multirow{2}{*}{$\begin{array}{l}\text { Natural } \\
\text { Ground- } \\
\text { water }\end{array}$} & 8.4 & $\sim 4.1 \times 10^{5}$ & $\sim 99$ & 1 & \\
\hline & & & & & $\sim 1.5 \times 10^{5}$ & $\sim 99$ & 96 & \\
\hline & & & \multirow{2}{*}{$\begin{array}{l}\text { Syn- } \\
\text { thetic } \\
\text { Ground- } \\
\text { water }\end{array}$} & 8.6 & $\sim 2.3 \times 10^{5}$ & $\sim 99$ & 0.5 & \\
\hline & & & & & $\sim 3.3 \times 10^{5}$ & $\sim 99$ & 96 & \\
\hline & & \multirow{4}{*}{$\begin{array}{l}\mathrm{Pu}(\mathrm{V}) \\
2.74 \times 10^{-7} \\
\mathrm{M}\end{array}$} & \multirow{2}{*}{$\begin{array}{l}\text { Natural } \\
\text { Ground- } \\
\text { water }\end{array}$} & 8.4 & 120 & 75 & 1 & \\
\hline & & & & & 171 & 81 & 96 & \\
\hline & & & \multirow{2}{*}{$\begin{array}{l}\text { Syn- } \\
\text { thetic } \\
\text { Ground- } \\
\text { water }\end{array}$} & 8.6 & $1.96 \times 10^{3}$ & 98 & 1 & \\
\hline & & & & & $1.96 \times 10^{3}$ & 98 & 96 & \\
\hline $\mathrm{Pu}$ & $\begin{array}{l}\text { Hematite } \\
<1 \mu \mathrm{m} \\
0.2 \mathrm{~g} / \mathrm{L}\end{array}$ & $\begin{array}{l}\mathrm{Pu}(\mathrm{V}) \\
2.74 \times 10^{-7} \\
\mathrm{M}\end{array}$ & $\begin{array}{l}\text { Yucca } \\
\text { Mt. well } \\
\text { J-13 } \\
\text { water }\end{array}$ & 8.2 & $4.9 \times 10^{3}$ & 50 & 1 & $\begin{array}{l}\text { Runde et al. (2002) } \\
\\
\text { Identified } \mathrm{Pu}(\mathrm{OH})_{4} \\
\text { and } \mathrm{PuO}_{2} \text { precipitated } \\
\text { phases. Increased } \\
\text { temperature, decreased } \\
\text { Pu solubility. }\end{array}$ \\
\hline
\end{tabular}

Powell et al. (2004, 2005) investigated the sorption and reduction of $\mathrm{Pu}(\mathrm{V})$ onto hematite, goethite and magnetite (containing $10-100 \mathrm{~m}^{2} / \mathrm{L}$ iron oxides) over the $\mathrm{pH}$ range 3-8 (Figure 2; Table 1). At $\mathrm{pH} \mathrm{3,} \mathrm{little} \mathrm{sorption} \mathrm{and} \mathrm{reduction} \mathrm{of} \mathrm{Pu}(\mathrm{V})$ was observed on either hematite (Figure 2A) or goethite (Figure 2B). The sorption rates of $\mathrm{Pu}(\mathrm{V})$ onto these iron oxides increase with increasing $\mathrm{pH}$ and the extended reaction time. At $\mathrm{pH} 5-8$, the sorption slowly reaches the steady state ( $\sim 7$ days), especially at the lower loadings of hematite, and $\mathrm{Pu}$ is essentially $100 \%$ removed at $\mathrm{pH} 8$, the overall removal of $\mathrm{Pu}(\mathrm{V})$ was found to be approximately second order with respect to hematite concentration. Oxidation state analysis of solutions at approximately neutral $\mathrm{pH}$ and $10 \mathrm{~m}^{2} / \mathrm{L}$ hematite showed a decrease in the fraction of $\mathrm{Pu}(\mathrm{V})$ in the total system (solid + aqueous) with a 
corresponding increase in the fraction of $\mathrm{Pu}(\mathrm{IV})$ in the total system. In contrast to hematite, $\mathrm{Pu}(\mathrm{V})$ sorption to goethite occurs rapidly relative to reduction. At a given $\mathrm{pH}$, the reduction rate is approximately independent of the goethite concentration, although $\mathrm{pH}$ has only a slight effect on the overall reaction rate. For magnetite (Figure 2C), at $\mathrm{pH} 3$, the sorption rates are much higher than those for hematite and goethite at the same $\mathrm{pH}$, which may indicate that reduction occurs in the aqueous phase. In the $\mathrm{pH}$ range of 5-8, sorption is rate-limiting step, and reduction is mediated by solid phase. The overall reaction was found to be approximately first order with respect to the magnetite concentration and of order $-0.34 \pm 0.02$ with respect to the $\mathrm{pH}$. The $\mathrm{Pu}(\mathrm{IV})$ solid phase species become more stable over time.

Goethite, hematite, and magnetite exhibit different sorption kinetics, which is related to the iron content of each mineral. Goethite and hematite are both Fe(III)-bearing minerals and magnetite is a mixed $\mathrm{Fe}(\mathrm{II} / \mathrm{III})$ mineral. Trace $\mathrm{Fe}(\mathrm{II})$ may facilitate the reduction of $\mathrm{Pu}(\mathrm{V})$ to $\mathrm{Pu}(\mathrm{IV})$. Thus, increasing the Fe(II) content of the system should correlate to an increase in reaction (sorption + reduction) kinetics. This expected trend was confirmed by Hixon et al. (2010), who observed a decrease in the rate of $\mathrm{Pu}(\mathrm{V})$ reduction to $\mathrm{Pu}(\mathrm{IV})$ when the concentration of Fe(II) in SRS sediments was decreased. Therefore, magnetite should exhibit faster kinetics than hematite or goethite. At approximately $50 \mathrm{~m}^{2} / \mathrm{L}$ of each mineral and $\mathrm{pH} 8$, kinetic reaction rate for magnetite is an order of magnitude higher than hematite or goethite (Powell et al. 2004, 2005).

Sanchez et al. (1985) studied the sorption of $\mathrm{Pu}(\mathrm{IV})$ and $\mathrm{Pu}(\mathrm{V})$ on goethite from $\mathrm{NaNO}_{3}$ $(0.1 \mathrm{M})$ solution that contained $28.5 \mathrm{~m}^{2} / \mathrm{L}$ or $0.55 \mathrm{~g} / \mathrm{L}$ goethite over the $\mathrm{pH}$ range of $2-10$ (Figure 3; Table 1). The sorption edge of the more strongly hydrolysable Pu(IV) occurs in the $\mathrm{pH}$ range of 3 to 5 . $\mathrm{Pu}(\mathrm{IV})$ sorption onto goethite increases rapidly with increasing $\mathrm{pH}$ to approximately $\mathrm{pH} 6$, at which a near-complete sorption and steady state are nearly achieved within 1 hour. Further increase in the equilibration time to 96 hours has little effect on its sorption behavior. An increase in the Pu concentration from $1 \times 10^{-11} \mathrm{M}$ to $1 \times 10^{-10} \mathrm{M}$ results in a slight decrease in sorption percentage from $\mathrm{pH} 2$ to 6 , which was not explained, but should not be due to the saturation of surface sites because at 28.5 $\mathrm{m}^{2} / \mathrm{L}$, there are approximately $10^{-4} \mathrm{M}$ sites available for Pu sorption. Therefore, the concentration of surface sites is 6-7 orders of magnitude greater than the Pu concentration. The authors modeled $\mathrm{Pu}(\mathrm{IV})$ sorption to goethite using three surface complexes:

$\equiv \mathrm{SOPu}(\mathrm{OH})_{2}{ }^{+2}$, $\equiv \mathrm{SOPu}(\mathrm{OH})_{3}{ }^{+}$, and $\equiv \mathrm{SOPu}(\mathrm{OH})_{4}$. This implies the inner-sphere sorption of $\mathrm{Pu}(\mathrm{IV})$ to the goethite surface. However, no spectroscopy results are available to confirm these surface species.

Under similar solution conditions, $\mathrm{Pu}(\mathrm{V})$ sorption to goethite is different than $\mathrm{Pu}(\mathrm{IV})$ sorption to goethite. No sorption is observed below $\mathrm{pH} \mathrm{4}$, sorption increases rapidly with increasing $\mathrm{pH}$. The sorption edge for $\mathrm{Pu}(\mathrm{V})$ is the $\mathrm{pH} 5$ to 7 , a near complete sorption occurs at approximately $\mathrm{pH}$. The sorption edge for $\mathrm{Pu}(\mathrm{V})$ shifts to lower $\mathrm{pH}$ values with contact time and this appears to be due to the reduction of $\mathrm{Pu}(\mathrm{V})$ to $\mathrm{Pu}(\mathrm{IV})$ in the presence of goethite surface. These results suggest that redox transformation is likely an important aspect of $\mathrm{Pu}$ sorption chemistry and the resulting scavenging of $\mathrm{Pu}$ from natural waters. Increasing ionic strength (from $0.1 \mathrm{M}$ to $3 \mathrm{M} \mathrm{NaCl}$ or $\mathrm{NaNO}_{3}$ and $0.03 \mathrm{M}$ 
to $0.3 \mathrm{M} \mathrm{Na}_{2} \mathrm{SO}_{4}$ ) does not influence $\mathrm{Pu}(\mathrm{V})$ sorption. In the presence of dissolved organic carbon (DOC), $\mathrm{Pu}(\mathrm{V})$ reduction to $\mathrm{Pu}(\mathrm{IV})$ occurs in solutions. $\mathrm{Pu}(\mathrm{IV})$ sorption on goethite decreased by $30 \%$ in the presence of $240 \mathrm{ppm}$ natural DOC. In addition, increasing concentrations of carbonate ligands to $100 \mathrm{meq} / \mathrm{L}$ (more specifically total alkalinity) had no effect on $\mathrm{Pu}(\mathrm{IV})$ or $\mathrm{Pu}(\mathrm{V})$ sorption to goethite. However, above 100 meq/L total alkalinity, the $\mathrm{Pu}(\mathrm{IV})$ and $\mathrm{Pu}(\mathrm{V})$ sorption on goethite systematically decreased until essentially all $\mathrm{Pu}$ was inhibited from sorption, presumably as a result of the formation of a Pu-CO $\mathrm{CO}_{3}$ complex (Sanchez et al. 1985). As shown in Figure 4, for both $\mathrm{Pu}(\mathrm{IV})$ and $\mathrm{Pu}(\mathrm{V})$, the carbonate alkalinity at $<100 \mathrm{meg} / \mathrm{L}$ shows little effect on the adsorption of $\mathrm{Pu}$ onto goethite; however, with further increase in carbonate alkalinity, the adsorption of $\mathrm{Pu}(\mathrm{IV})$ and $\mathrm{Pu}(\mathrm{V})$ onto goethite significantly decreases until their adsorption become essentially zero at the carbonate alkalinity $1000 \mathrm{meg} / \mathrm{L}$.

A.

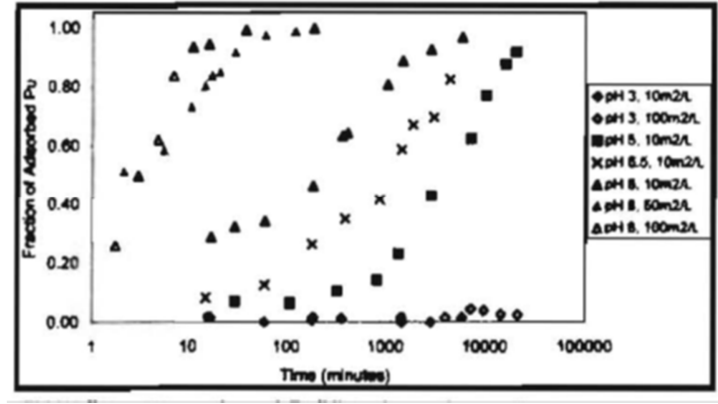

B.
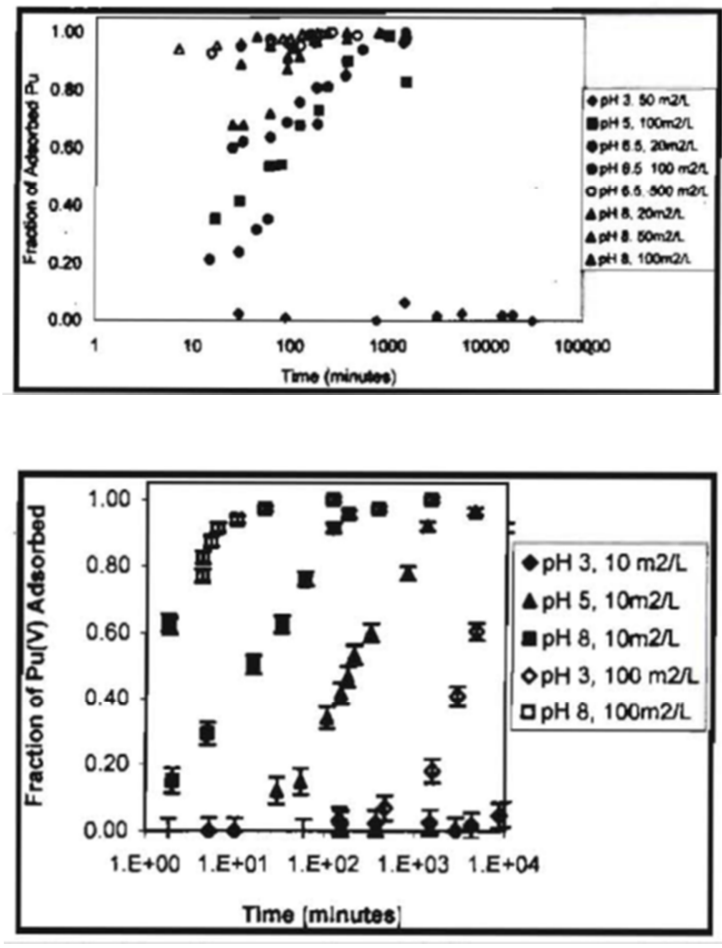

Figure 2. Sorption of $\mathrm{Pu}(\mathrm{V})$ on hematite (A), goethite (B) and magnetite (C) at different pH versus time (Powell et al. 2004, 2005). 

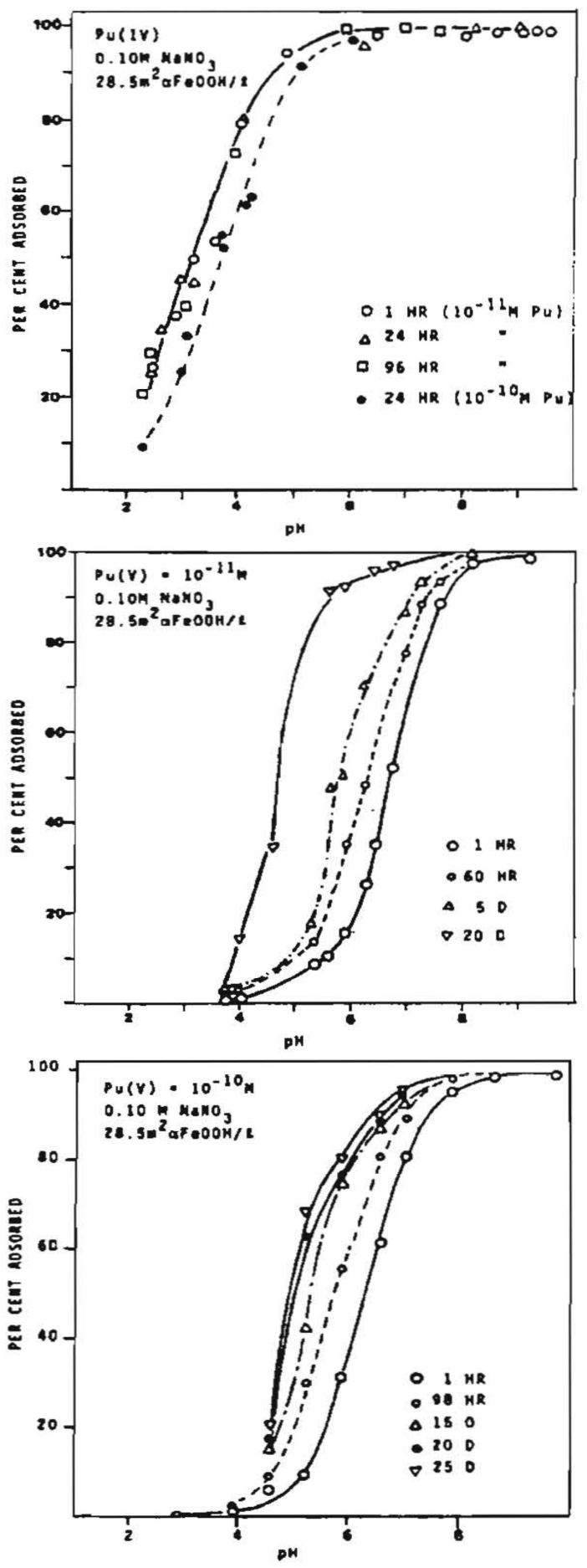

Figure 3. Top) Sorption of $\mathrm{Pu}(\mathrm{IV})$ on goethite as a function of $\mathrm{pH}$ from $0.1 \mathrm{M}$ $\mathrm{NaNO}_{3}$ solution at two plutonium concentrations $\left(1 \times 10^{-11}\right.$ and $\left.1 \times 10^{-10} \mathrm{M}\right)$. Middle $)$ The sorption of $\mathrm{Pu}(\mathrm{V})$ on goethite as a function of $\mathrm{pH}$ from $0.10 \mathrm{M} \mathrm{NaNO}_{3}$ solution at $1 \times 10^{-11} \mathrm{M}$. Bottom) Sorption of $\mathrm{Pu}(\mathrm{V})$ on goethite as a function of $\mathrm{pH}$ from $0.10 \mathrm{M}$ $\mathrm{NaNO}_{3}$ solution at $1 \times 10^{-10} \mathrm{M}($ Sanchez et al. 1985). 

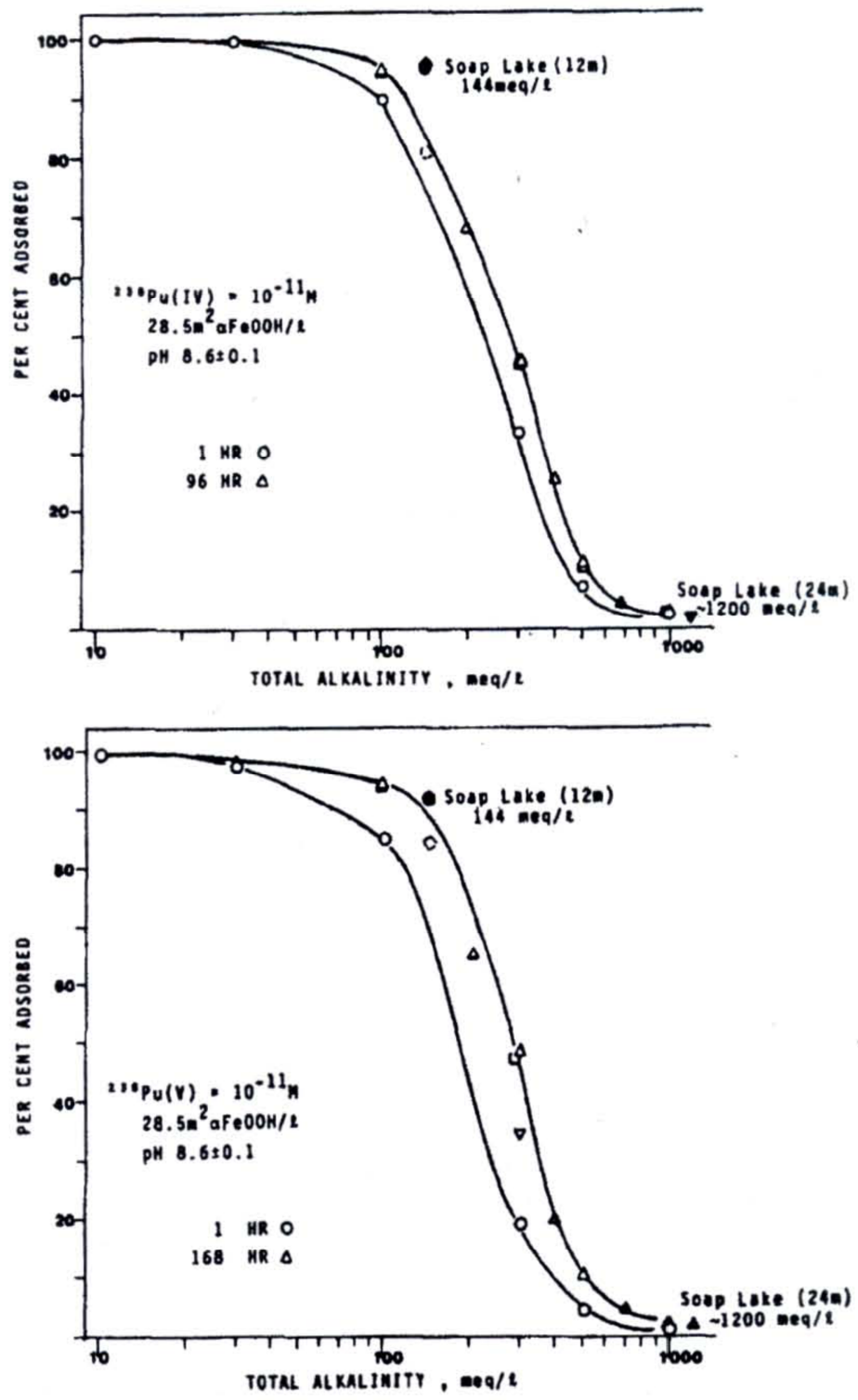

Figure 4. Top) The effect of carbonate alkalinity on the adsorption of $\mathrm{Pu}(\mathrm{IV})$ on goethite. Bottom) The effect of carbonate alkalinity on the adsorption of $\mathrm{Pu}(\mathrm{V}) \mathrm{pm}$ goethite. Adsorption from natural Soap Lake water is also shown (solid symbols) (Sanchez et al. 1985).

Lu et al. (1998, 2003) and Runde et al. (2002) studied the sorption of $\mathrm{Pu}(\mathrm{V})$ to hematite in Yucca Mountain J-13 well water; a $\mathrm{pH} 8, \mathrm{Ca}$ and carbonate dominated groundwater as shown in Table 1. Lu et al. $(1998,2003)$ observed that $50-55 \%$ of plutonium sorbed immediately after adding $\mathrm{Pu}(\mathrm{V})$ to solutions containing $1337.5 \mathrm{~m}^{2} / \mathrm{L}$ or $25 \mathrm{~g} / \mathrm{L}$ colloidal hematite. Over time, the $\mathrm{Pu}$ fraction associated with the solid phase slowly increased, 
until a steady-state was achieved after $\sim 4$ days. Similarly, Runde et al. (2002) showed that approximately $45 \%$ of plutonium sorbed upon initial mixing, the $\mathrm{Pu}$ fraction associated with the solid phases increased with time until a steady-state was reached around 4 days. Approximately $95 \%$ of the plutonium was sorbed at a steady-state. The $\mathrm{pH}$ of the solutions were not reported over time, but were assumed to be steady at the initial solution $\mathrm{pH} \sim 8$.

Kersting et al. (2003) studied the sorption of $\mathrm{Pu}(\mathrm{V})$ onto mineral colloids including goethite. The sorption of $\mathrm{Pu}(\mathrm{V})$ onto goethite is strong and fast. The initial soluble $\mathrm{Pu}(\mathrm{V})$ has ultimately been reduced to the $\mathrm{Pu}(\mathrm{IV})$ state on goethite. The mechanism for sorption of $\mathrm{Pu}(\mathrm{V})$ on goethite is that the $\mathrm{Pu}(\mathrm{V})$ sorbs rapidly, directly on goethite surface as $\mathrm{Pu}(\mathrm{V})$ and reduces to $\mathrm{Pu}(\mathrm{IV})$ as a result of interaction with goethite surface. Further, XANES spectra showed that $\mathrm{Pu}(\mathrm{IV})$ is the dominant oxidation state on goethite when plutonium is added as $\mathrm{Pu}(\mathrm{V})$. EXAFS analysis indicated the inner-sphere complexation of $\mathrm{Pu}(\mathrm{IV})$ with the goethite surface. Although evidence of plutonium-carbonate complexes exists, there are no $\mathrm{Pu}-\mathrm{Pu}$ interactions present that would represent precipitation of $\mathrm{Pu}(\mathrm{IV})$ on the goethite surface. The sorbed $\mathrm{Pu}(\mathrm{IV})$ species likely form edge-sharing bidentate between plutonium and iron octahedra, this means that two oxygen atoms in the $\mathrm{Pu}$ hydration sphere are shared with the goethite structure. However, there is no XAS data available in the literature for plutonium sorption to hematite or magnetite.

In addition, Kaplan et al. (2006) investigated the influence of $\mathrm{pH}$ on $\mathrm{Pu}$ desorption / solubilization from SRS sediments in which sand grains and clays are coated with goethite. They found that $>99 \%$ of the $\mathrm{Pu}$ adsorbs onto the sediment within 48 hours, $>94 \%$ of the aqueous $\mathrm{Pu}$ remains as $\mathrm{Pu}(\mathrm{V}),<6 \%$ as $\mathrm{Pu}(\mathrm{VI})$ and $<1 \%$ as $\mathrm{Pu}(\mathrm{IV})$; in contrast, the adsorbed $\mathrm{Pu}$ is exclusively $\mathrm{Pu}(\mathrm{IV})$. The fraction of aqueous $\mathrm{Pu}\left(\mathrm{Pu}_{\mathrm{aq}} / \mathrm{Pu}_{\text {solid }}\right)$ decreases by $>2$ orders of magnitude when the contact time was increased from 1 to 33 days, presumably the result of $\mathrm{Pu}(\mathrm{V})$ reduction to $\mathrm{Pu}(\mathrm{IV})$. After desorption, $96 \%$ of the $\mathrm{Pu}_{\mathrm{aq}}$ is $\mathrm{Pu}(\mathrm{V} / \mathrm{VI})$. The $\mathrm{Pu}_{\mathrm{aq}}$ concentrations from the desorption experiment are similar to those of the $\mathrm{Pu}(\mathrm{V})$ amended sorption studies that were permitted to equilibrate for 33 days, suggesting that the latter had reached steady state. The $\mathrm{Pu}_{\mathrm{aq}}$ concentrations as a function of $\mathrm{pH}$ follows near identical trends with literature solubility values for $\mathrm{PuO}_{2}(\mathrm{am})$, except that the desorption values are lower by over an order of magnitude, indicating that $\mathrm{pH}$ has a more pronounced effect on solubility and $\mathrm{Pu}_{\mathrm{aq}}$ concentrations than on sediment charge density (or $\mathrm{Pu}_{\mathrm{aq}}$ oxidation state distribution). Slight changes in system $\mathrm{pH}$ can have a large impact on $\mathrm{Pu}$ solubility and the tendency of $\mathrm{Pu}$ to sorb to sediment, thereby influencing $\mathrm{Pu}$ subsurface mobility. Hixon et al. also studied the influence of iron redox transformations on $\mathrm{Pu}$ sorption to SRS sediments and found that native $\mathrm{Fe}$ (II) in the sediments is responsible for the reduction of trace level $\mathrm{Pu}$ in the systems, in agreement with the iron oxide surface-mediated reduction mechanism of $\mathrm{Pu}(\mathrm{V})$ (Powell et al. 2004, 2005) and $\mathrm{Pu}(\mathrm{VI})$ (Romanchuk et al. 2011). 


\subsection{Uranium}

A summary of the uranium sorption information (adsorption coefficient $\mathrm{K}_{\mathrm{d}}$, adsorption percentage, initial $\mathrm{Pu}$ concentration, $\mathrm{pH}$, ion strength, equilibrium time, and sorbent loading) to iron oxyhydroxide phases is given in Table 2 .

There are more references related to uranium than plutonium sorption to oxyhydroxides (hematite, magnetite, goethite and ferrihydrites) as shown in Table 2. In $\mathrm{CO}_{2}$ or carbonate ligand free systems, uranyl $\left(\mathrm{UO}_{2}{ }^{2+}\right)$, monodentate $\left(\right.$ as $\left.\mathrm{UO}_{2} \mathrm{OH}^{+}\right)$and bi- or tri-dendate (as $\mathrm{UO}_{2}(\mathrm{OH})_{2}{ }^{0}$ and $\mathrm{UO}_{2}(\mathrm{OH})_{3}{ }^{-}$) are chief complexation species with increasing $\mathrm{pH}$ as shown in Figure 5 (Missana et al. 2003), although the detailed speciation may be slightly different from different model calculations (Hsi and Langmuir 1985 and Missana et al. 2003). As shown in Figure 6, the sorption profiles of $U$ onto these iron ox yhydroxides are generally similar and form S-type (or sigmoidal type) sorption edges at the $\mathrm{pH}$ range of $2-10$. The sorption is very little or near zero at $\mathrm{pH}<3$, the sorption increases dramatically with increasing $\mathrm{pH}$, a near complete sorption of $\mathrm{U}$ is normally achieved at the $\mathrm{pH} 5-6$ and remains until pH 10 studied (Hsi and Langmuir 1985, Waite et al. 1994, Payne et al. 1998, Missana et al. 2003, Tao et al. 2004, Zeng et al. 2009). In Figure 6, the sorption profiles of $U$ onto synthetic and natural hematite are slightly different from those for ferric hydroxide and goethite. This difference is probably due to the limited surface area, particle sizes and thus the limited available sorption sites of the hematite sorbents (Missana et al. 2003, Zeng et al. 2009). Ca and $\mathrm{Mg}$ at $10^{-3} \mathrm{M}$ do not significantly affect uranyl sorption (Hsi and Langmuir 1985), while the ion strength change of $\mathrm{NaNO}_{3}$ from $0.1 \mathrm{M}$ to $0.001 \mathrm{M}$ appears to have little influence on the sorption profiles of $\mathrm{U}$ onto iron oxides and hydroxides (Missana et al. 2003). In addition, the sorption of U onto iron oxides and hydroxides are fast and normally reach the steady state within 48 hours, and the sorption profiles are similar with the extended contact time up to 3 months (Missana et al. 2003). Mahoney et al. (2008) re-evaluated uranyl sorption onto hydrous ferric oxide using the diffuse layer model database.

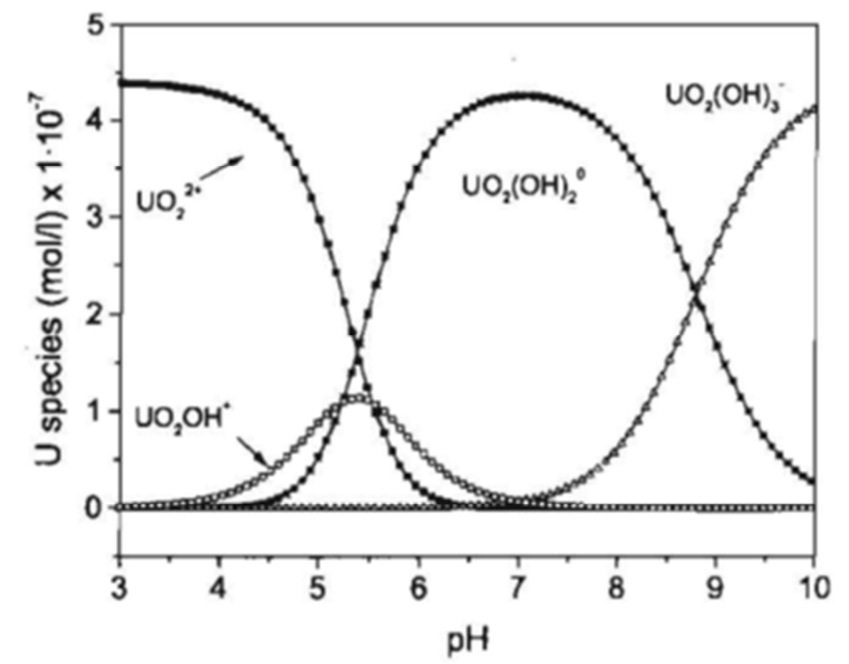

Figure 5. Aqueous speciation of uranium at $I=0.1 \mathrm{M} \mathrm{NaNO}_{3}$ and $[\mathrm{U}]=4.4 \times 10^{-7} \mathrm{M}$. Major species are shown only (Missana et al. 2003). 
Table 2. Uranium sorption to iron oxyhydroxide phases

\begin{tabular}{|c|c|c|c|c|c|c|c|c|}
\hline $\begin{array}{l}\text { Radio- } \\
\text { nuclide }\end{array}$ & Sorbents & Solution & $\begin{array}{l}\text { Ion } \\
\text { strength }\end{array}$ & pH & $\begin{array}{l}K_{d} \\
(m L / g)\end{array}$ & $\begin{array}{l}\text { Sorption } \\
(\%)\end{array}$ & $\begin{array}{l}\text { Equil } \\
\text { time } \\
\text { (hrs) }\end{array}$ & $\begin{array}{l}\text { Reference / } \\
\text { Description }\end{array}$ \\
\hline \multirow[t]{8}{*}{$\bar{U}$} & \multirow{8}{*}{$\begin{array}{l}\text { Ferri- } \\
\text { hydrite } \\
0.0005 \mathrm{M} \\
\text { or } 0.084 \\
\mathrm{~g} / \mathrm{L}\end{array}$} & \multirow{4}{*}{$\begin{array}{l}\mathrm{U} \\
1 \times 10^{-6} \mathrm{M} \\
\mathrm{P}_{\mathrm{CO} 2} \\
10^{-3.5} \mathrm{bar}\end{array}$} & \multirow{4}{*}{$\begin{array}{l}0.1 \mathrm{M} \\
\mathrm{NaNO}_{3}\end{array}$} & 3.5 & 120 & 1 & \multirow[t]{4}{*}{48} & \multirow{8}{*}{$\begin{array}{l}\text { Hiemstra } \text { et al. } \\
\text { (2009) } \\
\text { The sorption } \\
\text { profiles against } \mathrm{pH} \\
\text { are similar with (1) } \\
\text { the initial } \mathrm{U} \text { conc. } \\
\text { from } 0.01 \text { to } 100 \\
\mu \mathrm{M},(2) \text { with ion } \\
\text { strength from } 0.004 \\
\mathrm{M} \text { to } 0.5 \mathrm{M} \text {, and (3) } \\
\text { ferrihydrite loading } \\
\text { from } 0.0005 \mathrm{M} \text { to } \\
0.01 \mathrm{M} \text {. } \\
\text { The influence of } \\
\text { carbonate } \\
\text { complexes and } \\
\text { high pH on } \\
\text { uranium sorption is } \\
\text { far more } \\
\text { pronounced than } \\
\text { with Pu. }\end{array}$} \\
\hline & & & & 5.5 & $5.83 \times 10^{5}$ & 98 & & \\
\hline & & & & 8.2 & $2.26 \times 10^{5}$ & 95 & & \\
\hline & & & & 10 & 0 & 0 & & \\
\hline & & \multirow{4}{*}{$\begin{array}{l}\mathrm{U} \\
1 \times 10^{-6} \mathrm{M} \\
\mathrm{P}_{\mathrm{CO} 2} \\
0.01 \text { bar }\end{array}$} & \multirow{4}{*}{$\begin{array}{l}0.1 \mathrm{M} \\
\mathrm{NaNO}_{3}\end{array}$} & 3.0 & 120 & 1 & \multirow[t]{4}{*}{48} & \\
\hline & & & & 5.2 & $5.83 \times 10^{5}$ & 98 & & \\
\hline & & & & 6.8 & $1.18 \times 10^{6}$ & 99 & & \\
\hline & & & & 7.8 & 0 & 0 & & \\
\hline \multirow[t]{15}{*}{$\mathrm{U}$} & \multirow{4}{*}{$\begin{array}{l}\text { Hematite } \\
12 \mathrm{~nm} \\
1 \mathrm{~g} / \mathrm{L}\end{array}$} & \multirow{4}{*}{$\begin{array}{l}\mathrm{U} \\
1 \times 10^{-6} \mathrm{M}\end{array}$} & \multirow{4}{*}{$\begin{array}{l}0.01 \mathrm{M} \\
\mathrm{NaNO}_{3}\end{array}$} & 3.0 & 149 & 13 & \multirow[t]{4}{*}{48} & \multirow{15}{*}{$\begin{array}{l}\text { Zeng et al. (2009) } \\
\text { U Sorption onto } \\
\text { colloidal hematite } \\
\text { decreases and the } \\
\text { sorption edge shifts } \\
\text { toward higher pH } \\
\text { as the particle size } \\
\text { increased from } 12 \\
\text { to } 125 \mathrm{~nm} \text {. } \\
\text { However, the } \\
\text { coordination } \\
\text { environments of } \\
\text { adsorbed U(VI) } \\
\text { species are not } \\
\text { significantly } \\
\text { different on } \\
\text { hematite of } \\
\text { different sizes. }\end{array}$} \\
\hline & & & & 3.5 & $2.13 \times 10^{3}$ & 68 & & \\
\hline & & & & 4.1 & $\sim 9.9 \times 10^{4}$ & $\sim 99$ & & \\
\hline & & & & 10.2 & $\sim 9.9 \times 10^{4}$ & $\sim 99$ & & \\
\hline & \multirow{5}{*}{$\begin{array}{l}\text { Hematite } \\
70 \mathrm{~nm} \\
1 \mathrm{~g} / \mathrm{L}\end{array}$} & \multirow{5}{*}{$\begin{array}{l}\mathrm{U} \\
1 \times 10^{-6} \mathrm{M}\end{array}$} & \multirow{5}{*}{$\begin{array}{l}0.01 \mathrm{M} \\
\mathrm{NaNO}_{3}\end{array}$} & 3.0 & 0 & 0 & \multirow[t]{5}{*}{48} & \\
\hline & & & & 4.2 & 177 & 15 & & \\
\hline & & & & 5.0 & $1.5 \times 10^{3}$ & 60 & & \\
\hline & & & & 5.8 & $\sim 9.9 \times 10^{4}$ & $\sim 99$ & & \\
\hline & & & & 9.9 & $\sim 9.9 \times 10^{4}$ & $\sim 99$ & & \\
\hline & \multirow{5}{*}{$\begin{array}{l}\text { Hematite } \\
12 \mathrm{~nm} \\
1 \mathrm{~g} / \mathrm{L}\end{array}$} & \multirow{5}{*}{$\begin{array}{l}\mathrm{U} \\
1 \times 10^{-4} \mathrm{M}\end{array}$} & \multirow{5}{*}{$\begin{array}{l}0.01 \mathrm{M} \\
\mathrm{NaNO}_{3}\end{array}$} & 3.0 & 64 & 6 & \multirow[t]{5}{*}{48} & \\
\hline & & & & 4.0 & 667 & 40 & & \\
\hline & & & & 4.5 & $7.33 \times 10^{3}$ & 88 & & \\
\hline & & & & 5.8 & $\sim 9.90 \times 10^{4}$ & $\sim 99$ & & \\
\hline & & & & 10.2 & $\sim 9.9 \times 10^{4}$ & $\sim 99$ & & \\
\hline & Hematite & $\mathrm{U}$ & $0.01 \mathrm{M}$ & 4.0 & 0 & 0 & 48 & \\
\hline
\end{tabular}


SRNL-STI-2012-00040

Revision 0

\begin{tabular}{|c|c|c|c|c|c|c|c|c|}
\hline $\begin{array}{l}\text { Radio- } \\
\text { nuclide }\end{array}$ & Sorbents & Solution & $\begin{array}{l}\text { Ion } \\
\text { strength }\end{array}$ & pH & $\begin{array}{l}K_{d} \\
(m L / g)\end{array}$ & $\begin{array}{l}\text { Sorption } \\
(\%)\end{array}$ & $\begin{array}{l}\text { Equil } \\
\text { time } \\
\text { (hrs) }\end{array}$ & $\begin{array}{l}\text { Reference / } \\
\text { Description }\end{array}$ \\
\hline & $70 \mathrm{~nm}$ & $1 \times 10^{-4} \mathrm{M}$ & $\mathrm{NaNO}_{3}$ & 5.2 & 471 & 32 & & \\
\hline & & & & 6.9 & $3.0 \times 10^{3}$ & 75 & & \\
\hline & & & & 10.1 & $1.08 \times 10^{3}$ & 52 & & \\
\hline \multirow[t]{20}{*}{$\mathrm{U}$} & \multirow{20}{*}{\begin{tabular}{|l|} 
Goethite \\
$0.09 \mathrm{~g} / \mathrm{L}$
\end{tabular}} & \multirow{3}{*}{$\begin{array}{l}\mathrm{U} \\
1 \times 10^{-5} \mathrm{M} \\
\mathrm{P}_{\mathrm{CO} 2} \\
10^{-3.5} \text { bar }\end{array}$} & \multirow{3}{*}{$\begin{array}{l}0.09 \mathrm{M} \\
\mathrm{NaNO}_{3}\end{array}$} & 3.4 & 0 & 0 & \multirow[t]{3}{*}{24} & \multirow{20}{*}{$\begin{array}{l}\text { Sherman et al. } \\
(2008) \\
\text { The dominant } \\
\text { surface complex in } \\
\mathrm{CO}_{2} \text {-free systems } \\
\text { is a bidentate } \\
\text { corner-sharing } \\
\text { complex } \\
(\equiv \mathrm{FeOH})_{2} \mathrm{UO}_{2}\left(\mathrm{H}_{2} \mathrm{O}\right. \\
)_{3} . \text { Which can form } \\
\text { on the dominant } \\
\{101\} . \text { In the } \\
\text { presence of } \mathrm{CO}_{2}, \\
\mathrm{UO} \mathrm{O}_{2} \text { sorption at } \\
\text { lower pH is } \\
\text { enhanced due to } \\
\text { the formation of a } \\
(\equiv \mathrm{FeO}) \mathrm{CO}_{2} \mathrm{UO}_{2} \\
\text { ternary complex. } \\
\text { With pH increase, } \\
\mathrm{U}(\mathrm{VI}) \text { desorbs by } \\
\text { the formation of } \\
\text { aqueous carbonate } \\
\text { and hydroxyl } \\
\text { complexes. This } \\
\text { desorption is } \\
\text { preceded by the } \\
\text { formation of a } \\
\text { second ternary } \\
\text { surface complex } \\
(\equiv \mathrm{FeOH})_{2} \mathrm{UO}_{2} \mathrm{CO}{ }_{3} \text {. }\end{array}$} \\
\hline & & & & 6.5 & $1.0 \times 10^{5}$ & 90 & & \\
\hline & & & & 9.5 & 0 & 0 & & \\
\hline & & \multirow{4}{*}{$\begin{array}{l}\mathrm{U} \\
1 \times 10^{-6} \mathrm{M} \\
\mathrm{P}_{\mathrm{CO} 2} \\
10^{-3.5} \mathrm{bar}\end{array}$} & \multirow{4}{*}{\begin{tabular}{|l|}
$0.09 \mathrm{M}$ \\
$\mathrm{NaNO}_{3}$
\end{tabular}} & 3.5 & 463 & 4 & \multirow[t]{4}{*}{24} & \\
\hline & & & & 5.5 & $2.67 \times 10^{5}$ & 96 & & \\
\hline & & & & 8.0 & $8.15 \times 10^{4}$ & 88 & & \\
\hline & & & & 9.5 & 0 & 0 & & \\
\hline & & \multirow{4}{*}{$\begin{array}{l}\mathrm{U} \\
1 \times 10^{-7} \mathrm{M} \\
\mathrm{P}_{\mathrm{CO} 2} \\
10^{-3.5} \text { bar }\end{array}$} & \multirow{4}{*}{$\begin{array}{l}0.09 \mathrm{M} \\
\mathrm{NaNO}_{3}\end{array}$} & 3.5 & $1.96 \times 10^{3}$ & 15 & \multirow[t]{4}{*}{24} & \\
\hline & & & & 5.0 & $\sim 1.1 \times 10^{6}$ & $\sim 99$ & & \\
\hline & & & & 8.0 & $\sim 1.1 \times 10^{6}$ & $\sim 99$ & & \\
\hline & & & & 9.5 & 0 & 0 & & \\
\hline & & \multirow{3}{*}{$\begin{array}{l}\mathrm{U} \\
1 \times 10^{-5} \mathrm{M} \\
\mathrm{P}_{\mathrm{CO} 2}< \\
10^{-6} \text { bar }\end{array}$} & \multirow{3}{*}{$\begin{array}{l}0.09 \mathrm{M} \\
\mathrm{NaNO}_{3}\end{array}$} & 4.2 & 0 & 0 & \multirow[t]{3}{*}{48} & \\
\hline & & & & 7.5 & $2.11 \times 10^{5}$ & 95 & & \\
\hline & & & & 10 & $5.44 \times 10^{5}$ & 98 & & \\
\hline & & \multirow{3}{*}{$\begin{array}{l}\mathrm{U} \\
1 \times 10^{-6} \mathrm{M} \\
\mathrm{P}_{\mathrm{CO} 2}< \\
10^{-6} \text { bar }\end{array}$} & \multirow{3}{*}{$\begin{array}{l}0.09 \mathrm{M} \\
\mathrm{NaNO}_{3}\end{array}$} & 3.5 & 0 & 0 & \multirow[t]{3}{*}{48} & \\
\hline & & & & 6.2 & $5.44 \times 10^{5}$ & 98 & & \\
\hline & & & & 9.9 & $2.67 \times 10^{5}$ & 96 & & \\
\hline & & \multirow{3}{*}{$\begin{array}{l}\mathrm{U} \\
1 \times 10^{-7} \mathrm{M} \\
\mathrm{P}_{\mathrm{CO} 2}< \\
10^{-6} \text { bar }\end{array}$} & \multirow{3}{*}{$\begin{array}{l}0.09 \mathrm{M} \\
\mathrm{NaNO}_{3}\end{array}$} & 3.5 & 0 & 0 & \multirow[t]{3}{*}{48} & \\
\hline & & & & 5.5 & $\sim 1.1 \times 10^{6}$ & $\sim 99$ & & \\
\hline & & & & 9.9 & $\sim 1.1 \times 10^{6}$ & $\begin{array}{l}99 \\
\end{array}$ & & \\
\hline \multirow[t]{9}{*}{$\mathrm{U}$} & \multirow{6}{*}{$\begin{array}{l}\text { Hematite } \\
10 \mathrm{~g} / \mathrm{L}\end{array}$} & \multirow{6}{*}{$\begin{array}{l}\mathrm{UO}_{2}^{2+} \\
3.2 \times 10^{-5} \\
\mathrm{M}\end{array}$} & \multirow{6}{*}{$\begin{array}{l}0.1 \mathrm{M} \\
\mathrm{NaNO}_{3}\end{array}$} & 4 & 2.0 & 2 & \multirow[t]{6}{*}{36} & \multirow{9}{*}{$\begin{array}{l}\text { Tao et al. (2004) } \\
\text { The } \mathrm{UO}_{2}{ }^{2+} \text { sorption } \\
\text { edge occurs at } \mathrm{pH} \\
\text { 5-6. With ion } \\
\text { strength increase, } \\
\text { the sorption edge } \\
\text { shifts toward } \\
\text { higher pH and } \\
\text { become broader. }\end{array}$} \\
\hline & & & & 5.3 & 25 & 20 & & \\
\hline & & & & 5.5 & 67 & 40 & & \\
\hline & & & & 6.0 & 669 & 87 & & \\
\hline & & & & 8 & 567 & 85 & & \\
\hline & & & & 11 & $1.33 \times 10^{3}$ & 93 & & \\
\hline & \multirow{3}{*}{$\begin{array}{l}\text { Hematite } \\
10 \mathrm{~g} / \mathrm{L}\end{array}$} & $\mathrm{UO}_{2}{ }^{2+}$ & $0.01 \mathrm{M}$ & 3.2 & 3 & 3 & 36 & \\
\hline & & $\begin{array}{l}3.2 \times 10^{-5} \\
\mathrm{M}\end{array}$ & $\mathrm{NaNO}_{3}$ & 5.5 & 25 & 20 & & \\
\hline & & & & 5.8 & 100 & 50 & & \\
\hline
\end{tabular}


SRNL-STI-2012-00040

Revision 0

\begin{tabular}{|c|c|c|c|c|c|c|c|c|}
\hline $\begin{array}{l}\text { Radio- } \\
\text { nuclide }\end{array}$ & Sorbents & Solution & $\begin{array}{l}\text { Ion } \\
\text { strength }\end{array}$ & pH & $\begin{array}{l}K_{d} \\
(m L / g)\end{array}$ & $\begin{array}{l}\text { Sorption } \\
(\%)\end{array}$ & $\begin{array}{l}\text { Equil } \\
\text { time } \\
\text { (hrs) }\end{array}$ & $\begin{array}{l}\text { Reference / } \\
\text { Description }\end{array}$ \\
\hline & & & & 7.2 & $1.33 \times 10^{3}$ & 93 & & \\
\hline & & & & 10.2 & $1.9 \times 10^{3}$ & 95 & & \\
\hline & Hematite & $\mathrm{UO}_{2}{ }^{2+}$ & $0.001 \mathrm{M}$ & 4.4 & 4 & 4 & 36 & \\
\hline & & $\begin{array}{l}3.2 \times 10^{-3} \\
\mathrm{M}\end{array}$ & $\mathrm{NaNO}_{3}$ & 6.0 & 67 & 40 & & \\
\hline & & & & 7.3 & 488 & 83 & & \\
\hline & & & & 9.1 & $1.33 \times 10^{3}$ & 93 & & \\
\hline \multirow[t]{5}{*}{$\bar{U}$} & \multirow{5}{*}{$\begin{array}{l}\text { Goethite } \\
2 \mathrm{~g} / \mathrm{L}\end{array}$} & \multirow{5}{*}{$\begin{array}{l}\mathrm{U} \\
4.4 \times 10^{-7} \\
\mathrm{M} \\
\mathrm{O}_{2}, \mathrm{CO}_{2-} \\
\text { free }\end{array}$} & \multirow{5}{*}{$\begin{array}{l}0.1 \mathrm{M} \\
\mathrm{NaClO}_{4}\end{array}$} & 3.3 & 0 & 0 & \multirow[t]{5}{*}{360} & \multirow{5}{*}{$\begin{array}{l}\text { Missana } \text { et al. } \\
\text { (2003) } \\
\text { Profiles are same } \\
\text { for } 15 \text { days and } 3 \\
\text { months; shift } \\
\text { slightly to lower } \\
\text { pH with ion } \\
\text { strength change to } \\
0.001 \mathrm{M} \text {, to higher } \\
\text { pH with goethite } \\
\text { loading to } 0.16 \mathrm{~g} / \mathrm{L} \text {. }\end{array}$} \\
\hline & & & & 3.8 & 81 & 14 & & \\
\hline & & & & 4.8 & $2.83 \times 10^{3}$ & 85 & & \\
\hline & & & & 5.8 & $\sim 4.95 \times 10^{4}$ & $\sim 99$ & & \\
\hline & & & & 10.5 & $\sim 4.95 \times 10^{4}$ & $\sim 99$ & & \\
\hline \multirow[t]{4}{*}{$\mathrm{U}$} & \multirow{4}{*}{$\begin{array}{l}\text { Hematite } \\
\text { BET } 32.8 \\
\mathrm{~m}^{2} / \mathrm{g} \\
0.2 \mathrm{~g} / \mathrm{L}\end{array}$} & \multirow{4}{*}{$\begin{array}{l}\mathrm{U} \\
1 \times 10^{-6} \mathrm{M} \\
\mathrm{P}_{\mathrm{CO} 2} \\
1 \times 10^{-3.5} \\
\text { bar }\end{array}$} & \multirow{4}{*}{$\begin{array}{l}0.1 \mathrm{M} \\
\mathrm{NaNO}_{3}\end{array}$} & 4.0 & $1.1 \times 10^{3}$ & 18 & 24 & \multirow{4}{*}{$\begin{array}{l}\text { Bargar et al. (2000) } \\
\text { Dimeric hematite- } \\
\text { U(VI)-carbonate } \\
\text { ternary complexes } \\
\text { are identified. }\end{array}$} \\
\hline & & & & 4.0 & $1.49 \times 10^{3}$ & 23 & 120 & \\
\hline & & & & 8.9 & $1.94 \times 10^{3}$ & 28 & 24 & \\
\hline & & & & 8.9 & $2.58 \times 10^{3}$ & 34 & 120 & \\
\hline \multirow[t]{4}{*}{$\mathrm{U}$} & $\begin{array}{l}\text { Biogenic } \\
\text { Fe oxide } \\
\text { Fe } 3.92 \\
\text { moles per } \\
\text { kg solids }\end{array}$ & $\begin{array}{l}\mathrm{U} \\
6 \times 10^{-5} \mathrm{M}\end{array}$ & \multirow[t]{4}{*}{$\begin{array}{l}\text { Ground } \\
\text { water } \\
\text { with Cs, } \\
\mathrm{Sr}, \mathrm{Pb} \text {, } \\
\text { U, others }\end{array}$} & 8.3 & $4.37 \times 10^{3}$ & & 48 & \multirow{4}{*}{$\begin{array}{l}\text { Ferris et al. (2000) } \\
\text { Bacteriogenic Fe } \\
\text { oxides are } \\
\text { amorphous hydrous } \\
\text { ferric oxide and } \\
\text { ferrous iron } \\
\text { oxidizing bacteria. } \\
\mathrm{K}_{\mathrm{d}} \text { decreased with } \\
\text { the mass fraction of } \\
\text { reducible oxide, } \\
\text { implying that metal } \\
\text { uptake is strongly } \\
\text { influenced by } \\
\text { bacterial organic } \\
\text { matter. }\end{array}$} \\
\hline & $\begin{array}{l}\text { Biogenic } \\
\text { Fe oxide } \\
\text { Fe } 6.63 \\
\text { moles per } \\
\text { kg solids }\end{array}$ & $\begin{array}{l}\mathrm{U} 6 \times 10^{-5} \\
\mathrm{M}\end{array}$ & & 8.3 & $5.5 \times 10^{3}$ & & 48 & \\
\hline & $\begin{array}{l}\text { Biogenic } \\
\text { Fe oxide } \\
\text { Fe } 5.29 \\
\text { moles per } \\
\text { kg solids }\end{array}$ & $\begin{array}{l}\mathrm{U} \\
4.5 \times 10^{-5} \\
\mathrm{M}\end{array}$ & & 8.3 & $2.14 \times 10^{3}$ & & 48 & \\
\hline & $\begin{array}{l}\text { Biogenic } \\
\text { Fe oxide } \\
\text { Fe } 7.64 \\
\text { moles per } \\
\text { kg solids }\end{array}$ & $\begin{array}{l}\mathrm{U} \\
4.5 \times 10^{-5} \\
\mathrm{M}\end{array}$ & & 8.3 & $1.78 \times 10^{3}$ & & 48 & \\
\hline $\mathrm{U}$ & $\begin{array}{l}\text { Goethite } \\
10 \mathrm{~g} / \mathrm{L}\end{array}$ & $\begin{array}{l}\mathrm{U} \\
2 \times 10^{-6} \mathrm{M}\end{array}$ & & 3.7 & $\sim 9.9 \times 10^{3}$ & $\sim 99$ & 24 & Moyes et al. (2000) \\
\hline
\end{tabular}


SRNL-STI-2012-00040

Revision 0

\begin{tabular}{|c|c|c|c|c|c|c|c|c|}
\hline $\begin{array}{l}\text { Radio- } \\
\text { nuclide }\end{array}$ & Sorbents & Solution & $\begin{array}{l}\text { Ion } \\
\text { strength }\end{array}$ & pH & $\begin{array}{l}K_{d} \\
(m L / g)\end{array}$ & $\begin{array}{l}\text { Sorption } \\
(\%)\end{array}$ & $\begin{array}{l}\text { Equil } \\
\text { time } \\
\text { (hrs) }\end{array}$ & $\begin{array}{l}\text { Reference / } \\
\text { Description }\end{array}$ \\
\hline & & $\begin{array}{l}\mathrm{U} \\
4 \times 10^{-6} \mathrm{M}\end{array}$ & & 3.7 & 400 & 80 & & \multirow{6}{*}{$\begin{array}{l}\text { On both iron } \\
\text { hydroxides } \\
\text { uranium uptake } \\
\text { occurs by surface } \\
\text { complexation and } \\
\text { ceases when the } \\
\text { surface is saturated. } \\
\text { Bidentate inner- } \\
\text { sphere surface } \\
\text { complexes are } \\
\text { formed by } \\
\text { coordination of two } \\
\text { surface oxygens } \\
\text { from the iron } \\
\text { octahedron in the } \\
\text { equatorial plane of } \\
\text { the complex. }\end{array}$} \\
\hline & & $\begin{array}{l}\mathrm{U} \\
1 \times 10^{-5} \mathrm{M}\end{array}$ & & 3.7 & 67 & 40 & & \\
\hline & \multirow[t]{4}{*}{$\begin{array}{l}\text { Lepido- } \\
\text { crocite } \\
10 \mathrm{~g} / \mathrm{L}\end{array}$} & $\begin{array}{l}\mathrm{U} \\
2 \times 10^{-6} \mathrm{M}\end{array}$ & & $\begin{array}{l}3.6- \\
4.8\end{array}$ & $\sim 9.9 \times 10^{3}$ & $\sim 99$ & \multirow[t]{4}{*}{24} & \\
\hline & & $\begin{array}{l}\mathrm{U} \\
6 \times 10^{-6} \mathrm{M}\end{array}$ & & $\begin{array}{l}3.6- \\
4.8 \\
\end{array}$ & $\sim 9.9 \times 10^{3}$ & $\sim 99$ & & \\
\hline & & $\begin{array}{l}\mathrm{U} \\
1.2 \times 10^{-5} \\
\mathrm{M}\end{array}$ & & $\begin{array}{l}3.6- \\
4.8\end{array}$ & 100 & 50 & & \\
\hline & & $\begin{array}{l}\mathrm{U} \\
3 \times 10^{-5} \mathrm{M}\end{array}$ & & $\begin{array}{l}3.6- \\
4.8\end{array}$ & 30 & 23 & & \\
\hline \multirow[t]{4}{*}{$\mathrm{U}$} & \multirow{4}{*}{$\begin{array}{l}\text { Hematite } \\
0.53 \mathrm{~g} / \mathrm{L}\end{array}$} & \multirow{4}{*}{$\begin{array}{l}\mathrm{U} \\
5 \times 10^{-7} \mathrm{M} \\
\mathrm{CO}_{2} \text { free }\end{array}$} & \multirow{4}{*}{$\begin{array}{l}0.1 \mathrm{M} \\
\mathrm{NaNO}_{3}\end{array}$} & 4.3 & 596 & 24 & \multirow[t]{4}{*}{48} & \multirow{4}{*}{$\begin{array}{l}\text { Liger et al. (1999) } \\
\equiv \mathrm{Fe}-\mathrm{UO}_{2} \mathrm{OH} \text { is the } \\
\text { major sorption } \\
\text { species. }\end{array}$} \\
\hline & & & & 5.0 & $7.6 \times 10^{3}$ & 82 & & \\
\hline & & & & 5.6 & $6.1 \times 10^{4}$ & 97 & & \\
\hline & & & & 7.7 & $\sim 1.87 \times 10^{5}$ & $\sim 99$ & & \\
\hline \multirow[t]{12}{*}{$\bar{U}$} & \multirow{5}{*}{$\begin{array}{l}\text { Ferri- } \\
\text { hydrite } \\
600 \mathrm{~m}^{2} / \mathrm{g} \\
0.084 \mathrm{~g} / \mathrm{L}\end{array}$} & \multirow{5}{*}{$\begin{array}{l}\mathrm{U} \\
1 \times 10^{-6} \mathrm{M} \\
\mathrm{P}_{\mathrm{CO} 2} \\
1 \times 10^{-3.5} \\
\text { bar }\end{array}$} & \multirow{5}{*}{$\begin{array}{l}0.1 \mathrm{M} \\
\mathrm{NaNO}_{3}\end{array}$} & 3 & 118 & 1 & \multirow[t]{5}{*}{48} & \multirow{12}{*}{$\begin{array}{l}\text { Payne } \text { et al. (1998) } \\
\text { Waite } \text { et al. (1994) } \\
\text { To increase } \\
\text { ferrihydrite loading } \\
\text { to } 1.68 \mathrm{~g} / \mathrm{L} \text {, the } \\
\text { profile becomes } \\
\text { broader on both pH } \\
\text { side. To increase } \\
\mathrm{P}_{\mathrm{CO} 2} \text { to } 0.01 \text { bar, } \\
\text { the higher pH side } \\
\text { of profile shifts } \\
\text { toward lower pH. } \\
\text { To increase ion } \\
\text { strength, the profile } \\
\text { shifts to lower pH. } \\
\text { To add } 9 \text { mg/L } \\
\text { humic acid, the } \\
\text { profile becomes } \\
\text { slightly broader. }\end{array}$} \\
\hline & & & & 4.6 & $1.58 \times 10^{4}$ & 57 & & \\
\hline & & & & 5.4 & $3.85 \times 10^{5}$ & 97 & & \\
\hline & & & & 8.2 & $2.26 \times 10^{5}$ & 95 & & \\
\hline & & & & 10 & 0 & 0 & & \\
\hline & \multirow{7}{*}{$\begin{array}{l}\text { Ferrihydri } \\
\text { te } \\
600 \mathrm{~m}^{2} / \mathrm{g} \\
0.084 \mathrm{~g} / \mathrm{L}\end{array}$} & \multirow{7}{*}{$\begin{array}{l}\mathrm{U} \\
1 \times 10^{-4} \mathrm{M} \\
\mathrm{P}_{\mathrm{CO} 2} \\
1 \times 10^{-3.5} \\
\text { bar }\end{array}$} & \multirow{7}{*}{$\begin{array}{l}0.1 \mathrm{M} \\
\mathrm{NaNO}_{3}\end{array}$} & 4 & 0 & 0 & \multirow[t]{7}{*}{48} & \\
\hline & & & & 5 & $9.74 \times 10^{3}$ & 45 & & \\
\hline & & & & 5.5 & $4.22 \times 10^{4}$ & 78 & & \\
\hline & & & & 6.5 & $2.86 \times 10^{5}$ & 96 & & \\
\hline & & & & 7.5 & $8.73 \times 10^{4}$ & 88 & & \\
\hline & & & & 8 & $5.1 \times 10^{3}$ & 30 & & \\
\hline & & & & 8.8 & 0 & 0 & & \\
\hline \multirow[t]{2}{*}{$\mathrm{U}$} & \multirow{2}{*}{$\begin{array}{l}\text { Ferri- } \\
\text { hydrite } \\
\text { BET } 306\end{array}$} & \multirow{2}{*}{$\begin{array}{l}\mathrm{U} \\
1 \times 10^{-5} \mathrm{M} \\
\mathrm{CO}_{2} \text { free }\end{array}$} & \multirow{2}{*}{$\begin{array}{l}0.1 \mathrm{M} \\
\mathrm{NaNO}_{3}\end{array}$} & 3 & 110 & 10 & \multirow{2}{*}{$\begin{array}{l}\text { No } \\
\text { data }\end{array}$} & \multirow{2}{*}{$\begin{array}{l}\text { Hsi and Langmuir } \\
\text { (1985) }\end{array}$} \\
\hline & & & & 5.2 & $\sim 9.9 \times 10^{4}$ & $\sim 99$ & & \\
\hline
\end{tabular}


SRNL-STI-2012-00040

Revision 0

\begin{tabular}{|c|c|c|c|c|c|c|c|c|}
\hline $\begin{array}{l}\text { Radio- } \\
\text { nuclide }\end{array}$ & Sorbents & Solution & $\begin{array}{l}\text { Ion } \\
\text { strength }\end{array}$ & pH & $\begin{array}{l}\mathbf{K}_{\mathrm{d}} \\
(\mathrm{mL} / \mathrm{g})\end{array}$ & $\begin{array}{l}\text { Sorption } \\
(\%)\end{array}$ & $\begin{array}{l}\text { Equil } \\
\text { time } \\
\text { (hrs) }\end{array}$ & $\begin{array}{l}\text { Reference / } \\
\text { Description }\end{array}$ \\
\hline & $\begin{array}{l}\mathrm{m}^{2} / \mathrm{g} \\
1 \mathrm{~g} / \mathrm{L}\end{array}$ & & & 8.8 & $\sim 9.9 \times 10^{4}$ & $\sim 99$ & & \multirow{16}{*}{$\begin{array}{l}\mathrm{Ca} \text { and } \mathrm{Mg} \text { at } 10^{-3} \\
\mathrm{M} \text { did not } \\
\text { significantly affect } \\
\text { uranyl sorption. } \\
\text { Uranyl carbonate } \\
\text { and hydrocarbonate } \\
\text { severely inhibited } \\
\text { uranyl sorption. In } \\
\text { carbonate free } \\
\text { solution, } \\
\text { monodentate } \\
\mathrm{UO}_{2} \mathrm{OH}^{+} \text {and } \\
\text { mono-, bi- or tri- } \\
\text { dendate } \\
\left(\mathrm{UO}_{2}\right)_{3} \mathrm{OH}{ }^{+} \text {are } \\
\text { chief complexation } \\
\text { species. It was } \\
\text { necessary to } \\
\text { slightly vary the } \\
\text { intrinsic constants } \\
\text { for sorption of the } \\
\text { di- and tri- } \\
\text { carbonate } \\
\text { complexes to fit the } \\
\text { uranyl sorption } \\
\text { data at total } \\
\text { carbonate } \\
\text { concentration of } \\
10^{-2} \text { and } 10^{-3} \mathrm{M} \text {. }\end{array}$} \\
\hline & \multirow{3}{*}{$\begin{array}{l}\text { Goethite } \\
\text { BET } 45 \\
\mathrm{~m}^{2} / \mathrm{g} \\
1 \mathrm{~g} / \mathrm{L}\end{array}$} & \multirow{3}{*}{$\begin{array}{l}\mathrm{U} \\
1 \times 10^{-5} \mathrm{M} \\
\mathrm{CO}_{2} \text { free }\end{array}$} & \multirow{3}{*}{$\begin{array}{l}0.1 \mathrm{M} \\
\mathrm{NaNO}_{3}\end{array}$} & 3.6 & 220 & 18 & & \\
\hline & & & & 5.6 & $2.4 \times 10^{4}$ & 96 & & \\
\hline & & & & 9.0 & $\sim 9.9 \times 10^{4}$ & $\sim 99$ & & \\
\hline & \multirow{4}{*}{$\begin{array}{l}\text { Synthetic } \\
\text { hematite } \\
\text { BET } 3.1 \\
\mathrm{~m}^{2} / \mathrm{g} \\
1 \mathrm{~g} / \mathrm{L}\end{array}$} & \multirow{4}{*}{$\begin{array}{l}\mathrm{U} \\
1 \times 10^{-5} \mathrm{M} \\
\mathrm{CO}_{2} \text { free }\end{array}$} & \multirow{4}{*}{$\begin{array}{l}0.1 \mathrm{M} \\
\mathrm{NaNO}_{3}\end{array}$} & 4.1 & 0 & 0 & & \\
\hline & & & & 5.0 & 667 & 40 & & \\
\hline & & & & 6.6 & $1.5 \times 10^{3}$ & 60 & & \\
\hline & & & & 9.4 & $4.9 \times 10^{4}$ & 98 & & \\
\hline & \multirow{4}{*}{$\begin{array}{l}\text { Natural } \\
\text { hematite } \\
\mathrm{BET} 1.8 \\
\mathrm{~m}^{2} / \mathrm{g} \\
1 \mathrm{~g} / \mathrm{L}\end{array}$} & \multirow{4}{*}{$\begin{array}{l}\mathrm{U} \\
1 \times 10^{-5} \mathrm{M} \\
\mathrm{CO}_{2} \text { free }\end{array}$} & \multirow{4}{*}{$\begin{array}{l}0.1 \mathrm{M} \\
\mathrm{NaNO}_{3}\end{array}$} & 5 & 0 & 0 & & \\
\hline & & & & 5.5 & 250 & 20 & & \\
\hline & & & & 7 & $3.0 \times 10^{3}$ & 75 & & \\
\hline & & & & 9.5 & $1.63 \times 10^{3}$ & 62 & & \\
\hline & \multirow{3}{*}{$\begin{array}{l}\text { Goethite } \\
\text { BET } 45 \\
\mathrm{~m}^{2} / \mathrm{g} \\
1 \mathrm{~g} / \mathrm{L}\end{array}$} & \multirow{3}{*}{$\begin{array}{l}\mathrm{U} \\
1 \times 10^{-5} \mathrm{M} \\
\mathrm{CO}_{2} \text { free } \\
0.001 \mathrm{M} \\
\mathrm{NaHCO}_{3}\end{array}$} & \multirow{3}{*}{$\begin{array}{l}0.1 \mathrm{M} \\
\mathrm{NaNO}_{3}\end{array}$} & 3.9 & 250 & 20 & & \\
\hline & & & & 5.4 & $\sim 9.9 \times 10^{4}$ & $\sim 99$ & & \\
\hline & & & & 8.5 & $4.9 \times 10^{4}$ & 98 & & \\
\hline & $\begin{array}{l}\text { Goethite } \\
\text { BET } 45 \\
\mathrm{~m}^{2} / \mathrm{g} \\
1 \mathrm{~g} / \mathrm{L}\end{array}$ & $\begin{array}{l}\mathrm{U} \\
1 \times 10^{-5} \mathrm{M} \\
\mathrm{CO}_{2} \text { free } \\
0.01 \quad \mathrm{M} \\
\mathrm{NaHCO}_{3}\end{array}$ & $\begin{array}{l}0.1 \mathrm{M} \\
\mathrm{NaNO}_{3}\end{array}$ & 4.3 & $2.33 \times 10^{3}$ & 70 & & \\
\hline
\end{tabular}



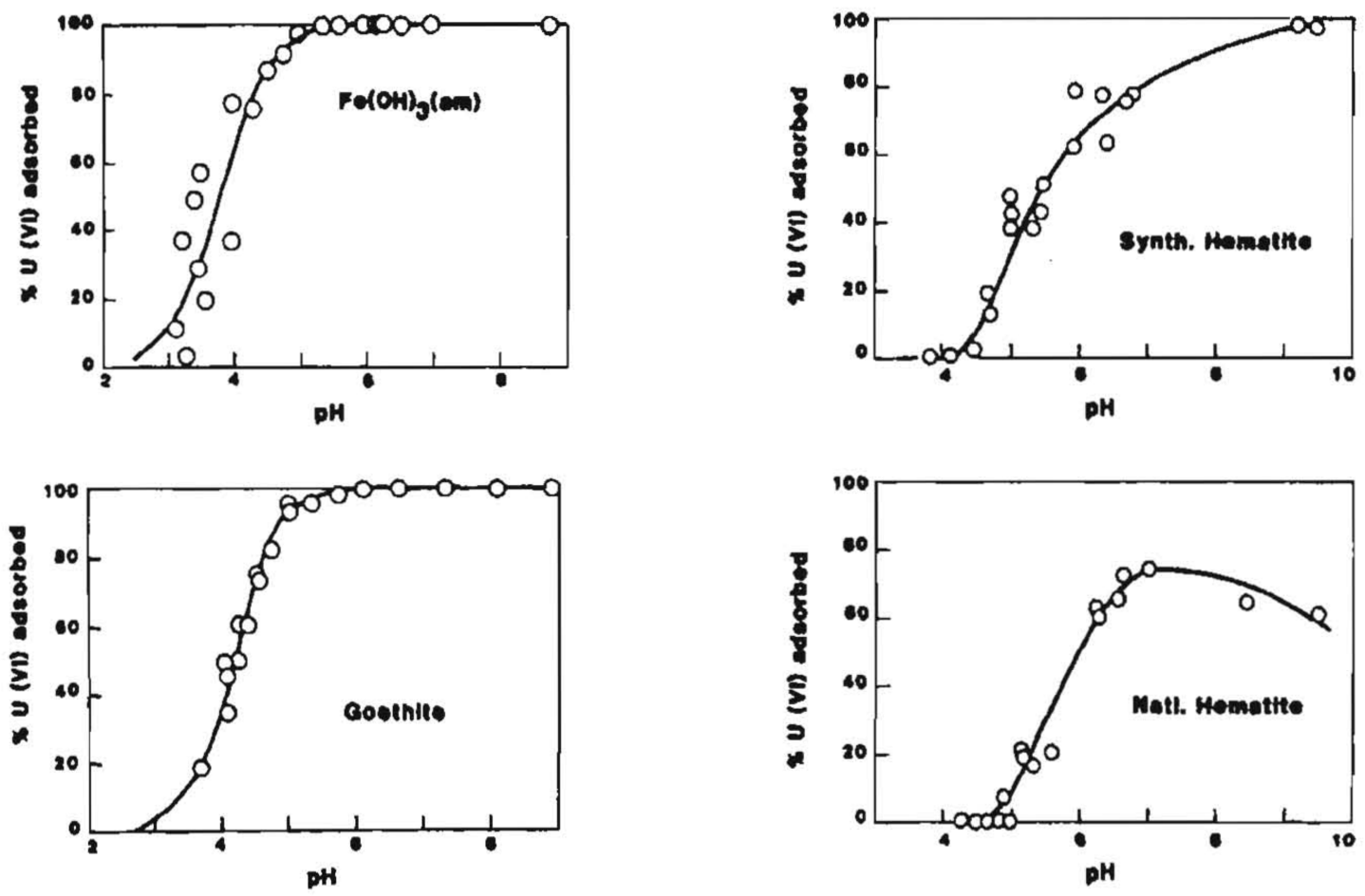

Figure 6. Sorption of uranyl versus $\mathrm{pH}$ at $\sum \mathrm{U}=1 \times 10^{-5} \mathrm{M}$ onto $1 \mathrm{~g} / \mathrm{L}$ suspension of ferri- hydroxide (left top), goethite (left bottom), synthetic hematite (right upper) and natural hematite (right bottom) in $0.1 \mathrm{M} \mathrm{NaNO}_{3}$ solutions at $25^{\circ} \mathrm{C}$. Symbols denote the experimental data, the solids curves are model calculated assume the given surface parameters and monodendate surface complexes of $\mathrm{UO}_{2} \mathrm{OH}^{+}$and $\left(\mathrm{UO}_{2}\right)_{3}(\mathrm{OH})_{5}{ }^{+}$with $\mathrm{p}^{*}$ Kins values of 8.0 and 15.0, respectively (Hsi and Langmuir 1985).

EXAFS studies indicated that the uranyl and hydrolyzed uranyl species form mononuclear bidentate complex $\left(\equiv \mathrm{Fe}(\mathrm{OH})_{2} \mathrm{UO}_{2}\left(\mathrm{H}_{2} \mathrm{O}\right)_{\mathrm{n}}\right.$ or $\mathrm{E} 2$ complex) with iron oxides and hydroxides, the two oxygen atoms of the distorted $\mathrm{U}-\mathrm{O}$ octahedral are shared with the Fe-O octahedron on the surface (Figure 11a, also Waite et al. 1994, Reich et al. 1998), while at higher $\mathrm{pH}$ or higher initial $\mathrm{U}$ concentration, the $\mathrm{U}$ species can form multiplenuclear polymerization or precipitates. However, more recently, Sherman et al. (2008) studied surface complexation of $\mathrm{U}(\mathrm{VI})$ on goethite $(\alpha-\mathrm{FeOOH})$. They argued that the previously proposed E2 complex, bidentate $\equiv \mathrm{Fe}(\mathrm{OH})_{2} \mathrm{UO}_{2}\left(\mathrm{H}_{2} \mathrm{O}\right)_{\mathrm{n}}$ complex, can only form on the $\{210\}$ or $\{010\}$ surface which comprise only small fraction $(\sim 1 \%)$ of goethite surface area. The U-Fe distance attributed previously to the E2 complex in EXAFS spectra can be fitted entirely by multiple scattering. At the same time, the effect of multiple scattering is to mask their proposed $\mathrm{C} 2$ complex (bidentate corner-sharing complex $\left.(=\mathrm{FeOH})_{2} \mathrm{UO}_{2}\left(\mathrm{H}_{2} \mathrm{O}\right)_{3}\right)$. Therefore, they proposed that the dominant surface complex in $\mathrm{CO}_{2}$-free systems is a $\mathrm{C} 2$, which can form on the dominant $\{101\}$ surface (Figure 7). 


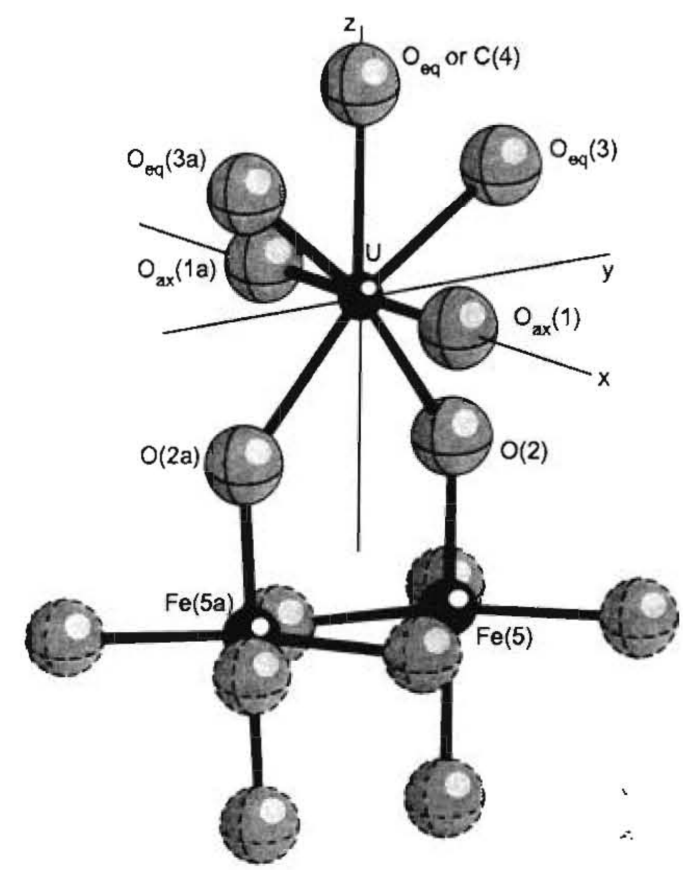

Figure 7. Cluster used in EXAFS fits for U(VI) sorbed to goethite (Sherman et al. 2008).

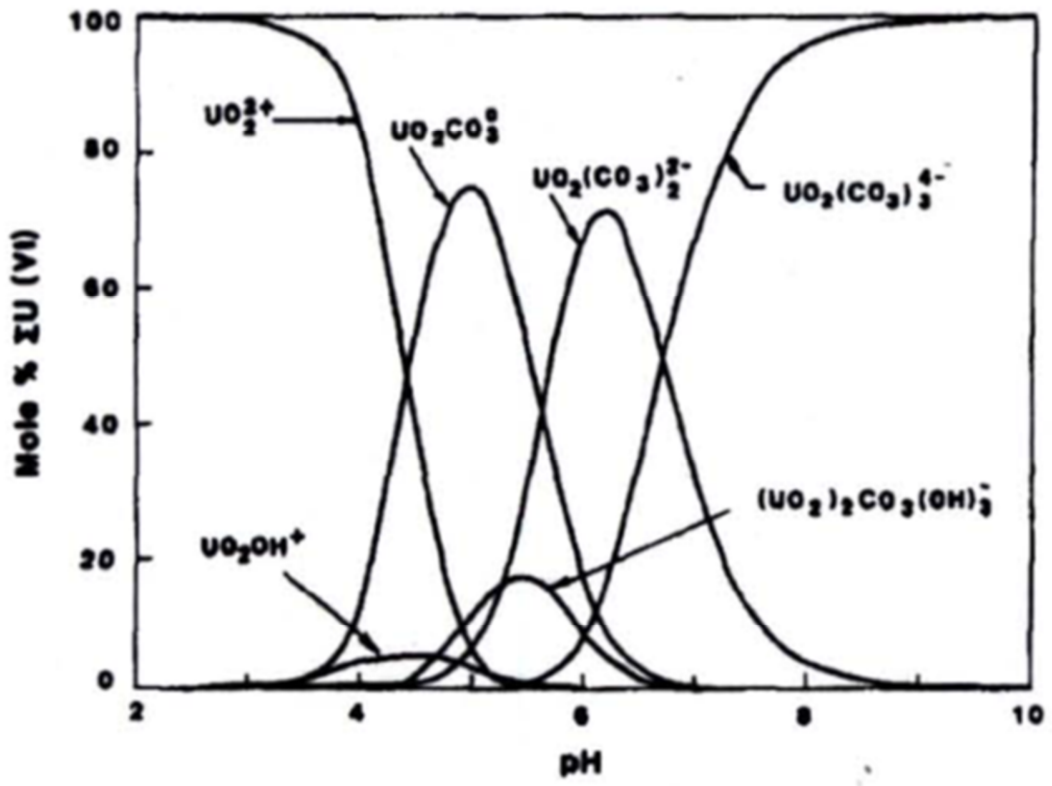

Figure 8. Distribution of uranyl-hydroxyl and carbonate complexes versus $\mathrm{pH}$ at $\Sigma \mathrm{U}=1 \times 10^{-5} \mathrm{M}$, total carbonate $0.01 \mathrm{M}$ in $0.1 \mathrm{M} \mathrm{NaNO}_{3}$ solutions at $25{ }^{\circ} \mathrm{C}$ (Hsi and Langmuir 1985). 
In the systems with $\mathrm{CO}_{2}$ or carbonate ligand, uranyl carbonate and hydrocarbonate complexes occur at $\mathrm{pH} 4$ and become dominant at higher $\mathrm{pH}$ (Figure 8), although the actual U complexes may be slightly different from different model calculations (Hsi and Langmuir 1985, Waite et al. 1998, Payne 1999, Sherman et al. 2008, Payne et al. 2011). It was necessary to slightly vary the intrinsic constants for sorption of the di- and tricarbonate complexes to fit the uranyl sorption data at a total carbonate concentration of $10^{-2}$ and $10^{-3} \mathrm{M}$ (Hsi and Langmuir 1985).

In the systems with $\mathrm{CO}_{2}$ or carbonate ligands, the sorption of $\mathrm{U}$ onto ferrihydrite and other iron oxides / hydroxides are fairly similar (Hsi and Langmuir 1985, Waite et al. 1998, Payne 1999, Bargar et al. 2000, Sherman et al. 2008, Hiemstra et al. 2009, Rossberg et al. 2009). As shown in Figure 9, the sorption of uranyl onto ferrihydrite is strongly dependent on $\mathrm{pH}$. At $\mathrm{pH}<4$, the sorption of $\mathrm{U}$ is very low, but the sorption of $U$ onto iron oxides and hydroxides increases sharply with $\mathrm{pH}$, the complete sorption is seen at $\mathrm{pH} \sim 5$ until $\mathrm{pH} 8$, the sorption of $U$ onto ferrihydrite decreases sharply starting from $\mathrm{pH} 8$, and essentially becomes non-existent at $\mathrm{pH}>9$. This differs greatly from $\mathrm{Pu}$, where at $\mathrm{pH}$ 9.8, plutonium sorption appears to be strong (Santchez et al. 1985) when the carbonate alkalinity is $<100 \mathrm{meq} / \mathrm{L}$. With an increase in the initial $\mathrm{U}(\mathrm{VI})$ concentration from $1 \times 10^{-8} \mathrm{M}$ to $1 \times 10^{-4} \mathrm{M}$ (Figure 9 , left upper), the sorption profiles are similar, but the left-side edge shift slightly toward higher $\mathrm{pH}$ and the right-side edge to lower $\mathrm{pH}$. With an increase in the sorbent loading from $0.001 \mathrm{M} \mathrm{Fe}$ or $0.084 \mathrm{~g} / \mathrm{L}$ ferrihydrite to $0.02 \mathrm{M} \mathrm{Fe}$ or $1.68 \mathrm{~g} / \mathrm{L}$ (Figure 9 , left bottom), the left-side edge slightly shifts to lower $\mathrm{pH}$, and the right-side edge to higher $\mathrm{pH}$. The sorption of $\mathrm{U}(\mathrm{VI})$ shows little change with the ion strength from $0.004 \mathrm{M}$ to $0.5 \mathrm{M} \mathrm{NaNO}_{3}$ (Figure 9, right upper). However, with $\mathrm{CO}_{2}$ partial pressure increase from $1 \times 10^{-3.5}$ bar to 0.02 bar, the right-side edge shifts toward lower pH (Figure 9, right bottom) (Hiemstra et al. 2009, Waite et al. 1998, Payne 1999).

The uranyl carbonate and hydrocarbonate complexes severely inhibit uranyl sorption onto iron oxides and hydroxides (Hsi and Langmuir 1985). Duff and Amrhein (1996) also suggested that U(VI)-carbonate ternary complexes should adsorb weakly on goethite. Hiemstra et al. proposed that in the presence of carbonates, the total concentration of $\mathrm{U}(\mathrm{VI})$ in solutions may increase as a result of desorption. This is more clearly seen at high $\mathrm{pH}$. Desorption is mainly due to the formation of dissolved uranyl-carbonate complexes such as $\mathrm{UO}_{2} \mathrm{CO}_{3}{ }^{0}(\mathrm{aq}), \mathrm{UO}_{2}\left(\mathrm{CO}_{3}\right)_{2}{ }^{2-}$ (aq) and $\mathrm{UO}_{2}\left(\mathrm{CO}_{3}\right)_{3}{ }^{4-}$ (aq). Desorption of uranyl is counteracted by the sorption of carbonate ions to the ferrihydrite surface. The coordination environment of the ferrihydrite surface may limit the complexity of U(VI) surface speciation in comparison to that observed in aqueous solution. Binding of 1:1 uranyl-carbonate complex at the surface is suggested from the results of batch sorption study and associated surface complexation modeling; however, coordination of U(VI) with two or more carbonate ligands may prevent surface coordination (Waite et al. 1994). 

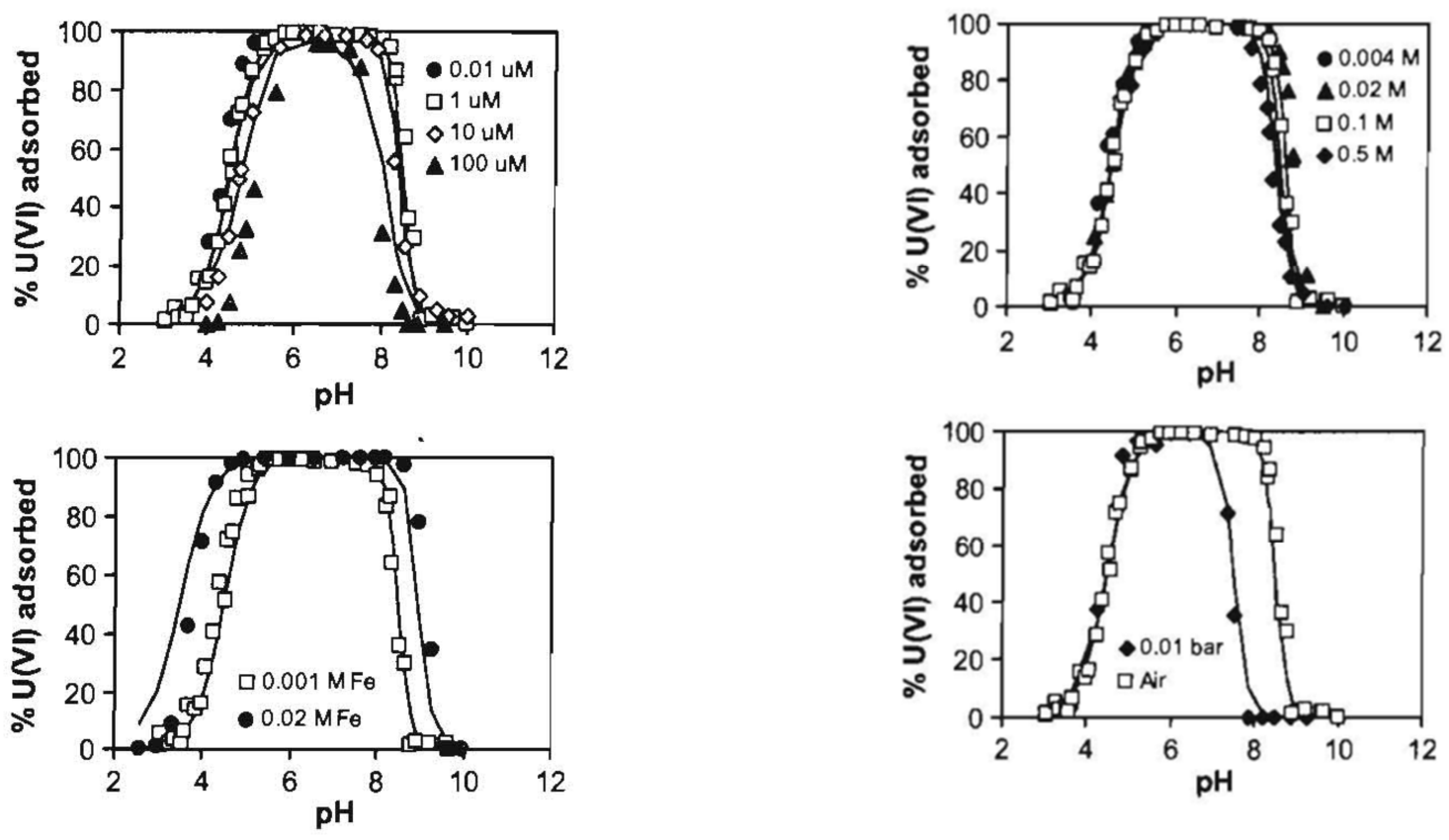

Figure 9. The fraction of uranyl adsorbed to ferrihydrite as a function of pH from 2 to 10 in the open systems. All systems are based on $1 \times 10^{-3} \mathrm{M}$ Fe or $0.084 \mathrm{~g} / \mathrm{L}$ ferrihydrite, $P_{\mathrm{CO} 2}=10^{-3.5}$ bar, and an initial $U(V)$ concentration of $1 \times 10^{-6} \mathrm{M}$, unless otherwise indicated in the figures. The sorption of $U$ onto ferihydrite with (1) initial $\mathrm{U}$ concnetration (left upper), (2) ferrihydrite loading (left bottom), (3) ion strength of $\mathrm{NaNO}_{3}$ (right upper), and (4) $\mathrm{CO}_{2}$ partial pressure (right bottom) (Payne et al. 1998, Payne 1999, Hiemstra et al. 2009).

However, Bargar et al. (2000) measured U(VI) sorption on hematite using EXAFS spectroscopy and electrophoresis under conditions relevant to surface waters and aquifers ( 0.01 to $10 \mathrm{mM}$ dissolved uranium concentrations, in equilibrium with air, $\mathrm{pH} 4.5$ to 8.5 ). Both techniques suggest the existence of anionic U(VI)-carbonato ternary complexes. Computational modeling of the EXAFS portion of the spectra indicate that U(VI) is simultaneously coordinated to surface $\mathrm{FeO}_{6}$ octahedra and carbonate (or bicarbonate) ligands in bidentate fashions. The ternary complexes have an inner-sphere metal bridging (hematite-U(VI)-carbonato) structure (Figure 10). About $\geq 50 \%$ of adsorbed U(VI) is comprised of monomeric hematite-U(VI)-carbonato ternary complexes, even at $\mathrm{pH} 4.5$. Multimeric U(VI) species were observed at $\mathrm{pH} \geq 6.5$ and aqueous $\mathrm{U}(\mathrm{VI})$ concentrations approximately an order of magnitude more dilute than the solubility of crystalline $\beta$ $\mathrm{UO}_{2}(\mathrm{OH})_{2}$. Based on structural constraints, these complexes were interpreted as dimeric hematite-U(VI)-carbonato ternary complexes. These results suggest that Fe-oxide-U(VI)carbonato complexes are likely to be important transport-limiting species in oxic aquifers throughout a wide range of $\mathrm{pH}$ values. 

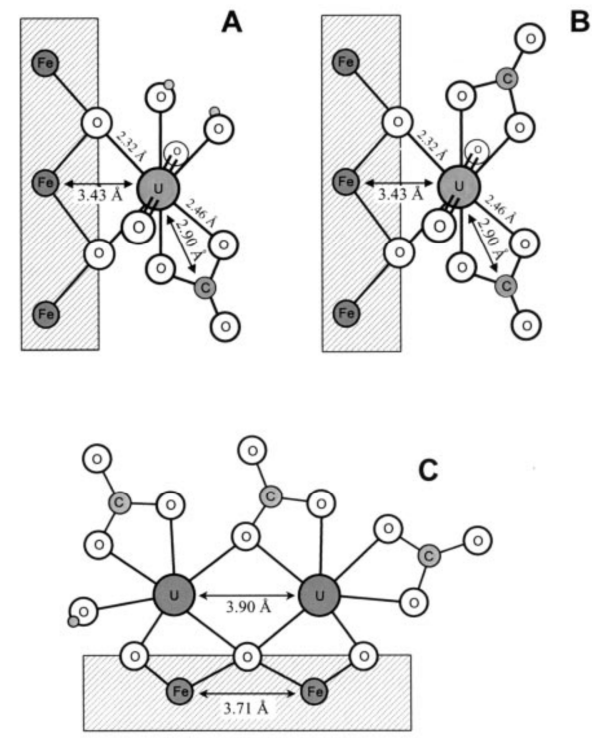

Figure 10. Structural models for postulated $\equiv \mathrm{Fe}(\mathrm{OH})_{2}\left(\mathrm{UO}_{2}\right)\left(\mathrm{OH}, \mathrm{H}_{2} \mathrm{O}\right)_{4-2 \mathrm{t}}\left(\mathrm{CO}_{3}\right)_{\mathrm{t}}$ complexes on hematite. (A) $t=1,(B) t=2$, (C) proposed dimeric $\equiv \mathrm{Fe}_{2} \mathrm{O}_{3}\left(\mathrm{UO}_{2}\right)_{2}(\mathrm{OH}$, $\left.\mathrm{H}_{2} \mathrm{O}\right)_{7-2 \mathrm{t}}\left(\mathrm{CO}_{3}\right)_{\mathrm{t}}$ bonded to edge-sharing $\mathrm{FeO}_{6}$ octahedra. To illustrate the dimension mismatch between the multimeric complexes and hematite, $\mathrm{Fe}$ atoms are shown with the maximum $\mathrm{Fe}-\mathrm{Fe}$ separation found in hematite for neighboring $\mathrm{FeO}_{6}$ octahedra (Bargar et al. 2000).

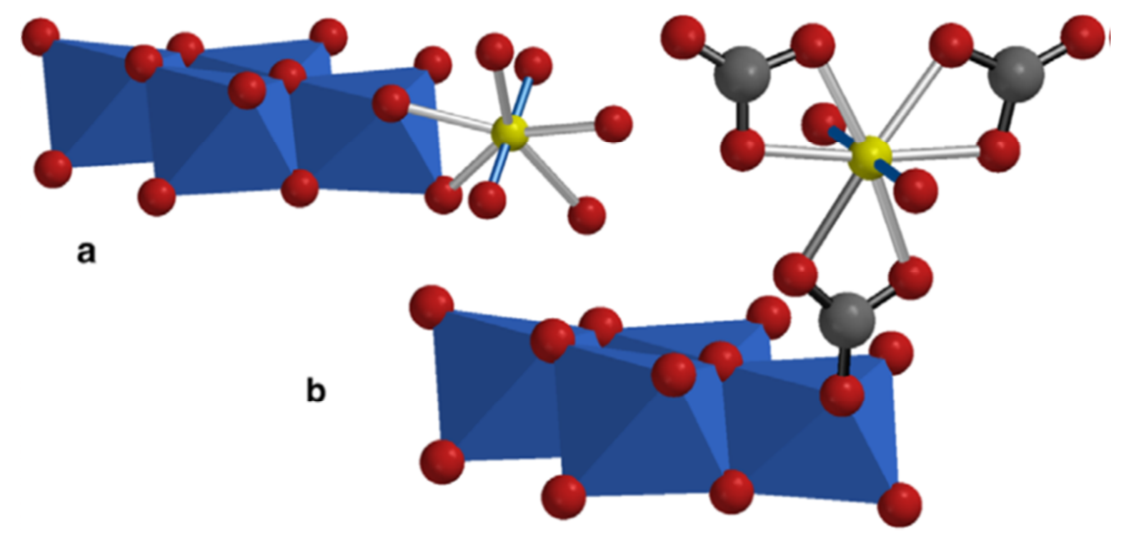

Figure 11. Representation of the most prominent uranyl surface complexes in open systems. (a) Uranyl bound by two singly-coordinated surface group present at a free edge. For this geometry with $\mathrm{d}(\mathrm{Fe}-\mathrm{U})=3.45 \AA$ and $\mathrm{d}\left(\mathrm{U}-\mathrm{O}_{\text {edge }}\right)=2.49 \AA, \mathrm{d}(\mathrm{O}-\mathrm{O})_{\text {edge }}$ is $2.87 \AA$. The outer ligand of the uranyl surface complex in (a) may be $\mathrm{OH}, \mathrm{OH}_{2}$, or $\mathrm{CO}_{3}$ (not shown). (b) A uranyl tris-carbonate complex that is singly-coordinated to a Fe ion in the solid via a carbonate group (Hiemstra et al. 2009, Rossberg et al. 2009). 
More recently, Rossberg et al. (2009) and Hiemstra et al. (2009) reinvestigated the identity and structural coordination of uranyl sorption complexes onto ferrihydrite in a range of conditions $\left(\mathrm{pH}, \mathrm{CO}_{2}\right.$ partial pressure, ionic strength, $\mathrm{U}(\mathrm{VI})$ concentration, and ferrihydrite loading) using a combination of $\mathrm{U}_{\mathrm{III}}$-edge extended X-ray absorption fine structure (EXAFS) spectroscopy and iterative transformation factor analysis. They found that their results can only be quantified and explained by two structurally different types of uranyl surface complexes (Figure 11): (1) a binary uranyl surface complex with a bidentate coordination to edges of $\mathrm{Fe}(\mathrm{O}, \mathrm{OH})_{6}$ octahedra and (2) a uranyl tris-carbonato surface complex $\left(\equiv\left(\mathrm{UO}_{2}\right)\left(\mathrm{CO}_{3}\right)_{3}{ }^{4-}\right)$ where one carbonate ion bridges uranyl to the surface. Both surface complexes agree qualitatively and quantitatively with predictions by a charge distribution (CD) model. The first uranyl surface complex has equatorial ligands $\left(-\mathrm{OH}_{2},-\mathrm{OH}\right.$, or one $-\mathrm{CO}_{3}$ group) that point away from the surface, and the uranyl complex is directly attached to surface atoms by edge-sharing with $\operatorname{Fe}(\mathrm{O}, \mathrm{OH})_{6}$ octahedron on ferrihydrite surface. The second uranyl-tri-carbonate complex forms monodentate surface complex through one $\mathrm{CO}_{3}$ group to bridge uranyl and ferrihydrite surface. This species is most abundant in systems with a high $\mathrm{pH}$ and carbonate concentration. At these conditions, however, it is responsible for significant uranyl sorption, whereas standard models would predict only weak sorption, which has significant implications for immobilization of uranyl in carbonate-rich aqueous environments. At high uranyl concentrations, uranyl polymerizes at the surface of ferrihydrite giving, for instance, tris-uranyl surface complexes with and without carbonate.

Steward et al. (2010) studied and quantified the influence of $\mathrm{Ca}$ and carbonate on the impact of uranyl speciation and on the sorption of $U$ onto goethite. Calcium and carbonate were introduced into the solution system containing $U$ and goethite at defined levels to provide a range of aqueous uranyl species. U(VI) sorption is directly linked to $\mathrm{UO}_{2}{ }^{2+}$ speciation, with the extent of retention decreasing with formation of ternary uranyl-calcium-carbonate species. Sorption isotherms under conditions studied are linear, and $\mathrm{K}_{\mathrm{d}}$ values decrease from 48 to $17 \mathrm{~L} / \mathrm{kg}$ for goethite as Ca concentration increases from 0 to $1 \mathrm{mM}$ at $\mathrm{pH}$ 7. These observations reveal that, in carbonate-bearing waters, neutral to slightly acidic $\mathrm{pH}$ values $(\sim 5)$ and limited dissolved calcium are optimal for uranium sorption. Steward et al. (2011) further investigated the impact of U(VI) speciation on the extent and rate of reduction, with specific emphasis on the effect of dissolved $\mathrm{Ca}$, and the impact of $\mathrm{Fe}(\mathrm{III})$ (hydr)oxides (ferrihydrite, goethite and hematite) on reduction. The amount of $U$ removed from solution during $100 \mathrm{~h}$ of incubation with $S$. putrefaciens is $77 \%$ with no Ca or ferrihydrite present, but only $24 \%$ (with ferrihydrite) and $14 \%$ (no ferrihydrite) are removed for systems with $0.8 \mathrm{mM} \mathrm{Ca}$. Goethite and hematite decrease the dissolved $\mathrm{Ca}$ concentration through sorption and thus tend to diminish the effect of $\mathrm{Ca}$ on uranium reduction. They revealed the predominant influence of uranyl speciation, specifically the formation of uranyl-calcium-carbonate complexes, and ferrihydrite on the rate and extent of $U$ reduction in complex geochemical systems.

In addition, Duff et al. (2002) studied uranium co-precipitation with iron oxide minerals in solutions of $\mathrm{U}(\mathrm{VI})$ and $\mathrm{Fe}(\mathrm{III})$. They found that $\mathrm{U}(\mathrm{VI})$ is incorporated in the Fe oxide as urinate (without axial $\mathrm{O}$ atoms) until a point of saturation is reached. Beyond this 
excess in $\mathrm{U}$ concentration, precipitating $\mathrm{U}(\mathrm{VI})$ forms discrete crystalline uranyl phases that resemble the uranyl oxide hydrate schoepite $\left[\mathrm{UO}_{2}(\mathrm{OH})_{2} \cdot 2 \mathrm{H}_{2} \mathrm{O}\right]$. Nico et al. (2009) studied the form of solid phase $\mathrm{U}$ after $\mathrm{Fe}(\mathrm{II})$ induced anaerobic remineralization of ferrihydrite in the presence of aqueous and absorbed U(VI) under both abiotic batch and biotic flow conditions. In synthetic ground waters containing $0.168 \mathrm{mM} \mathrm{U}(\mathrm{VI}), 3.8 \mathrm{mM}$ carbonate, and $3.0 \mathrm{mM} \mathrm{Ca}{ }^{2+}$, in spite of the high solubility of $\mathrm{U}(\mathrm{VI})$ under these conditions, appreciable removal of $\mathrm{U}(\mathrm{VI})$ from solution was observed in both the abiotic and biotic systems. The majority of the removed $\mathrm{U}$ was determined to be substituted as oxidized $\mathrm{U}(\mathrm{U}(\mathrm{VI})$ or $\mathrm{U}(\mathrm{V}))$ into the octahedral position of the goethite and magnetite formed during ferrihydrite remineralization. The produced solids were shown to be resistant to both extraction ( $30 \mathrm{mM} \mathrm{KHCO}$ ) and oxidation (air for 5 days), suggesting the potential importance of sequestration in Fe oxides as a stable and immobile form of $\mathrm{U}$ in the environment.

Aamrani et al. (2007) studied the sorption of $U$ onto magnetite as a main product of anoxic steel corrosion using X-ray photo electron spectroscopy (XPS) and extended Xray absorption spectroscopy (XAS). They did not specify the sorption percentage or $\mathrm{K}_{\mathrm{d}}$ of $\mathrm{U}$ on magnetite although a high sorption was expected. However, the EXAFS results indicated that the magnetite samples with $\mathrm{U}$ sorption has characteristics of both $\mathrm{UO}_{2}$ and schoepite, and U species adsorbed onto magnetite would be a mixture of U(VI) and $\mathrm{U}(\mathrm{IV})$. Duro et al. (2008) found that under anoxic conditions, $\mathrm{U}(\mathrm{VI})$ is adsorbed onto magnetite surface, whereas under reducing conditions at different $\mathrm{H}_{2}(\mathrm{~g})$ pressures, $\mathrm{U}$ is present in tetravalent form as amorphous $\mathrm{UO}_{2}$.

Rovira et al. (2007) further investigated the influence of the steel corrosion products on the radionuclides released from the fuel. In this study, steel coupons were reacted to form magnetite on their surfaces by anaerobic steel corrosion in an autoclave reactor at an overpressure of 8 atmosphere of $\mathrm{H}_{2}(\mathrm{~g})$. The corroded steel coupons, which were confirmed to form magnetite on their surfaces by X-ray diffraction, were contacted with a $\mathrm{U}(\mathrm{VI})$ solution at two different $\mathrm{H}_{2}(\mathrm{~g})$ pressures (1 and 7.6 atmospheres). The $\mathrm{U}$ concentrations in the solutions were monitored and determined, and the compositions of the coupons were studied at the end of this experiment. They concluded that magnetite generated on steel coupons is able to not only retain $U$ as a sorption, but also reduce $\mathrm{U}(\mathrm{VI})$ to $\mathrm{U}(\mathrm{IV})$ to a higher extent than commercial magnetite, thus providing an effective retardation path to the migration of uranium (and, potentially, other actinides) out of repository

\subsection{Neptunium}

A summary of the neptunium sorption information (adsorption coefficient $\mathrm{K}_{\mathrm{d}}$, adsorption percentage, initial $\mathrm{Pu}$ concentration, $\mathrm{pH}$, ion strength, equilibrium time, and sorbent loading) to iron oxyhydroxide phases is given in Table 3.

In the solution systems containing $\mathrm{Np}(\mathrm{V}) 4.5 \times 10^{-13}$ to $4.5 \times 10^{-11} \mathrm{M}$ and $0.1 \mathrm{M} \mathrm{NaNO}_{3}$ at $25{ }^{\circ} \mathrm{C}$, little $\mathrm{Np}(\mathrm{V})$ sorbs onto ferrihydrite at $\mathrm{pH} \leq 4.5$ (Table 3). Above that $\mathrm{pH}, \mathrm{Np}$ sorption onto ferrihydrite increases gradually with increasing $\mathrm{pH}$ until $\mathrm{pH} 8, \mathrm{~Np}(\mathrm{~V})$ is 
almost completely sorbed by ferrihydrite at $\mathrm{pH}$ 8-10 (Girvin et al. 1991). The S-type sorption edge shifts toward lower $\mathrm{pH}$ with an increase in the ferrihydrite loading. The dominant aqueous $\mathrm{NpO}_{2}{ }^{+}$sorbes onto ferrihydrite surface to form $\mathrm{NpO}_{2}(\mathrm{OH})^{0}$ surface complex. In natural groundwater systems like Yucca Mountain J-13 well waters, $\mathrm{Np}(\mathrm{V})$ sorption onto hematite $(<1 \mu \mathrm{m})$ at $0.2 \mathrm{~g} / \mathrm{L}$ is fairly low at $\mathrm{pH} \sim 8$ and its kinetic reaction is also slow (Runde et al. 2002), although another report indicated that $\mathrm{Np}(\mathrm{V})$ incrementally but steadily sorbs onto hematite at $\mathrm{pH}$ from 5 to 10 (Jain et al. 2007).

Table 3. Neptunium sorption to iron oxyhydroxide phases

\begin{tabular}{|c|c|c|c|c|c|c|c|c|}
\hline $\begin{array}{l}\text { Radio- } \\
\text { nuclide }\end{array}$ & Sorbents & Solution & $\begin{array}{l}\text { Ion } \\
\text { strength }\end{array}$ & pH & $\begin{array}{l}\mathrm{K}_{\mathrm{d}} \\
(\mathrm{mL} / \mathrm{g})\end{array}$ & $\begin{array}{l}\text { Sorp- } \\
\text { tion } \\
(\%)\end{array}$ & $\begin{array}{l}\text { Equil } \\
\text { time } \\
\text { (hrs) }\end{array}$ & $\begin{array}{l}\text { Reference / } \\
\text { Description }\end{array}$ \\
\hline \multirow[t]{5}{*}{$\mathrm{Np}$} & \multirow{5}{*}{$\begin{array}{l}\text { Hematite } \\
<1 \mu \mathrm{m} \\
0.2 \mathrm{~g} / \mathrm{L}\end{array}$} & \multirow{5}{*}{$\begin{array}{l}\mathrm{Np}(\mathrm{V}) \\
1.9 \times 10^{-7} \\
\mathrm{M}\end{array}$} & \multirow{5}{*}{$\begin{array}{l}\text { Yucca } \\
\text { Mt. well } \\
\text { J-13 } \\
\text { water }\end{array}$} & 8.19 & 319 & 6 & 1 & \multirow{5}{*}{$\begin{array}{l}\text { Runde et al. } \\
(2002) \\
\text { Np uptake was } \\
\text { much less than } \mathrm{Pu} \\
\text { uptake by } \\
\text { comparable } \\
\text { minerals. }\end{array}$} \\
\hline & & & & 8.19 & 435 & 8 & 24 & \\
\hline & & & & 8.19 & 682 & 12 & 50 & \\
\hline & & & & 8.19 & 556 & 10 & 90 & \\
\hline & & & & 8.19 & 747 & 13 & 240 & \\
\hline \multirow[t]{14}{*}{$\mathrm{Np}$} & \multirow{4}{*}{$\begin{array}{l}\text { Hematite } \\
3 \mathrm{~g} / \mathrm{L} \\
\text { Aerobic }\end{array}$} & \multirow{4}{*}{$\begin{array}{l}\mathrm{Np}(\mathrm{V}) \\
1 \times 10^{-13} \\
\mathrm{M}\end{array}$} & \multirow{4}{*}{$\begin{array}{l}0.1 \mathrm{M} \\
\mathrm{NaClO}_{4}\end{array}$} & 4 & 25 & 7 & \multirow[t]{4}{*}{48} & \multirow{14}{*}{$\begin{array}{l}\text { Jain et al. (2007) } \\
\\
\text { At } \mathrm{pH}<5 \text {, the } \\
\text { sorption of } \mathrm{Np}(\mathrm{V}) \\
\text { onto hematite is } \\
\text { negligible, beyond } \\
\text { which the sorption } \\
\text { sharply increases } \\
\text { up to } 90 \% \text { at } \mathrm{pH} \\
10 . \text { Presence of } \\
\text { humic acid } \\
\text { decreases the } \\
\text { sorption of Np(V) } \\
\text { on hematite at } \\
\text { higher pH, but } \\
\text { this effect is } \\
\text { negligible at } \\
\text { lower pH. Under } \\
\text { nitrogen and in } \\
\text { presence of } \\
\text { sodium dithionite, } \\
\text { Np(V) is reduced } \\
\text { to Np(IV) and } \\
\text { sorption was } \\
\text { enhanced at all } \\
\text { pHs. }\end{array}$} \\
\hline & & & & 6.2 & 94 & 22 & & \\
\hline & & & & 7.5 & $1.16 \times 10^{3}$ & 77 & & \\
\hline & & & & 9.6 & $3.83 \times 10^{3}$ & 92 & & \\
\hline & \multirow{3}{*}{$\begin{array}{l}\text { Hematite } \\
3 \mathrm{~g} / \mathrm{L} \\
\text { Humic acid } \\
2 \mathrm{mg} / \mathrm{L} \\
\text { Aerobic }\end{array}$} & \multirow{3}{*}{$\begin{array}{l}\mathrm{Np}(\mathrm{V}) \\
1 \times 10^{-13} \\
\mathrm{M}\end{array}$} & \multirow{3}{*}{$\begin{array}{l}0.1 \mathrm{M} \\
\mathrm{NaClO}_{4}\end{array}$} & 4 & 10 & 3 & \multirow[t]{3}{*}{48} & \\
\hline & & & & 6.8 & 94 & 22 & & \\
\hline & & & & 10.2 & $2.44 \times 10^{3}$ & 88 & & \\
\hline & \multirow{4}{*}{$\begin{array}{l}\text { Hematite } \\
3 \mathrm{~g} / \mathrm{L} \\
\text { Humic acid } \\
2 \mathrm{mg} / \mathrm{L} \\
\text { Anaerobic }\end{array}$} & \multirow{4}{*}{$\begin{array}{l}\mathrm{Np}(\mathrm{IV}) \\
1 \times 10^{-13} \\
\mathrm{M}\end{array}$} & \multirow{4}{*}{$\begin{array}{l}0.1 \mathrm{M} \\
\mathrm{NaClO}_{4}\end{array}$} & 4.1 & 222 & 40 & \multirow[t]{4}{*}{48} & \\
\hline & & & & 5.6 & $1.18 \times 10^{3}$ & 78 & & \\
\hline & & & & 7.9 & $1.63 \times 10^{4}$ & 98 & & \\
\hline & & & & 9.5 & $6.33 \times 10^{3}$ & 95 & & \\
\hline & \multirow{3}{*}{$\begin{array}{l}\text { Hematite } \\
3 \mathrm{~g} / \mathrm{L} \\
\text { Anaerobic }\end{array}$} & \multirow{3}{*}{$\begin{array}{l}\mathrm{Np}(\mathrm{IV}) \\
1 \times 10^{-13} \\
\mathrm{M}\end{array}$} & \multirow{3}{*}{$\begin{array}{l}0.1 \mathrm{M} \\
\mathrm{NaClO}_{4}\end{array}$} & 4.3 & 73 & 18 & \multirow[t]{3}{*}{48} & \\
\hline & & & & 6.5 & $1.25 \times 10^{3}$ & 79 & & \\
\hline & & & & 9.9 & $5.22 \times 10^{3}$ & 94 & & \\
\hline \multirow[t]{3}{*}{$\mathrm{Np}$} & \multirow{3}{*}{$\begin{array}{l}\text { Amorphous } \\
\text { Fe } \\
\text { oxyhydroxide } \\
0.89 \mathrm{~g} / \mathrm{L}\end{array}$} & \multirow{3}{*}{$\begin{array}{l}\mathrm{Np}(\mathrm{V}) \\
4.5 \times 10^{-11} \\
\mathrm{M} \\
4.7 \times 10^{-12}\end{array}$} & \multirow{3}{*}{$\begin{array}{l}0.1 \mathrm{M} \\
\mathrm{NaNO}_{3}\end{array}$} & 4 & 23 & 2 & \multirow[t]{3}{*}{24} & \multirow{3}{*}{$\begin{array}{l}\text { Girvin et al. } \\
\text { (1991) } \\
\text { At } N p(V)\end{array}$} \\
\hline & & & & 5 & 183 & 14 & & \\
\hline & & & & 6 & $2.89 \times 10^{3}$ & 72 & & \\
\hline
\end{tabular}


SRNL-STI-2012-00040

Revision 0

\begin{tabular}{|c|c|c|c|c|c|c|c|c|}
\hline $\begin{array}{l}\text { Radio- } \\
\text { nuclide }\end{array}$ & Sorbents & Solution & $\begin{array}{l}\text { Ion } \\
\text { strength }\end{array}$ & pH & $\begin{array}{l}\mathbf{K}_{\mathrm{d}} \\
(\mathrm{mL} / \mathrm{g})\end{array}$ & $\begin{array}{l}\text { Sorp- } \\
\text { tion } \\
(\%)\end{array}$ & $\begin{array}{l}\text { Equil } \\
\text { time } \\
\text { (hrs) }\end{array}$ & $\begin{array}{l}\text { Reference / } \\
\text { Description }\end{array}$ \\
\hline & & \multirow{3}{*}{$\begin{array}{l}\mathrm{M} \\
4.5 \times 10^{-13} \\
\mathrm{M}\end{array}$} & & 7 & $2.7 \times 10^{4}$ & 96 & & \multirow{18}{*}{$\begin{array}{l}\text { concentration } \\
4.5 \times 10^{-13} \mathrm{M} \text { to } \\
4.5 \times 10^{-11} \mathrm{M}, \mathrm{Np} \\
\text { sorption onto } \\
\text { amorphous } \mathrm{Fe} \\
\text { oxyhydroxide } \\
\text { increases from } \mathrm{pH} \\
2 \text { to } \mathrm{pH} 8 \text {. The } \\
\text { aqueous } \mathrm{NpO}_{2}^{+} \\
\text {species is } \\
\text { dominant. To } \\
\text { increase the Fe } \\
\text { sorbent loading } \\
\text { would shift the } \\
\text { sorption edge } \\
\text { toward lower } \mathrm{pH} \text {. }\end{array}$} \\
\hline & & & & 8 & $\sim 1.11 \times 10^{5}$ & $\sim 99$ & & \\
\hline & & & & 9 & $\sim 1.11 \times 10^{5}$ & $\sim 99$ & & \\
\hline & \multirow{4}{*}{$\begin{array}{l}\text { Amorphous } \\
\text { Fe } \\
\text { oxyhydroxide } \\
0.89 \mathrm{~g} / \mathrm{L}\end{array}$} & \multirow{4}{*}{$\begin{array}{l}\mathrm{Np}(\mathrm{V}) \\
4.7 \times 10^{-12} \\
\mathrm{M}\end{array}$} & \multirow{4}{*}{$\begin{array}{l}0.1 \mathrm{M} \\
\mathrm{NaNO}_{3}\end{array}$} & 4.2 & $\sim 11$ & $\sim 1$ & \multirow[t]{4}{*}{24} & \\
\hline & & & & 5.1 & 336 & 23 & & \\
\hline & & & & 6.0 & $3.37 \times 10^{3}$ & 75 & & \\
\hline & & & & 7.0 & $2.14 \times 10^{4}$ & 95 & & \\
\hline & \multirow{5}{*}{$\begin{array}{l}\text { Amorphous } \\
\text { Fe } \\
\text { oxyhydroxide } \\
0.33 \mathrm{~g} / \mathrm{L}\end{array}$} & \multirow{5}{*}{$\begin{array}{l}\mathrm{Np}(\mathrm{V}) \\
4.7 \times 10^{-12} \\
\mathrm{M}\end{array}$} & \multirow{5}{*}{$\begin{array}{l}0.1 \mathrm{M} \\
\mathrm{NaNO}_{3}\end{array}$} & 4.3 & 31 & 1 & \multirow[t]{5}{*}{24} & \\
\hline & & & & 5.3 & 535 & 15 & & \\
\hline & & & & 5.9 & $3.03 \times 10^{3}$ & 50 & & \\
\hline & & & & 6.9 & $2.73 \times 10^{4}$ & 90 & & \\
\hline & & & & 7.7 & $5.76 \times 10^{4}$ & 95 & & \\
\hline & \multirow{6}{*}{$\begin{array}{l}\text { Amorphous } \\
\text { Fe } \\
\text { oxyhydroxide } \\
0.09 \mathrm{~g} / \mathrm{L}\end{array}$} & \multirow{6}{*}{$\begin{array}{l}\mathrm{Np}(\mathrm{V}) \\
4.7 \times 10^{-12} \\
\mathrm{M}\end{array}$} & \multirow{6}{*}{$\begin{array}{l}0.1 \mathrm{M} \\
\mathrm{NaNO}_{3}\end{array}$} & 4.1 & 227 & 2 & \multirow[t]{6}{*}{24} & \\
\hline & & & & 5.2 & 709 & 6 & & \\
\hline & & & & 5.8 & $2.78 \times 10^{3}$ & 20 & & \\
\hline & & & & 6.9 & $2.59 \times 10^{4}$ & 70 & & \\
\hline & & & & 7.8 & $1.0 \times 10^{5}$ & 90 & & \\
\hline & & & & 9.0 & $1.1 \times 10^{6}$ & 99 & & \\
\hline
\end{tabular}

\subsection{Americium}

A summary of the americium sorption information (adsorption coefficient $\mathrm{K}_{\mathrm{d}}$, adsorption percentage, initial $\mathrm{Pu}$ concentration, $\mathrm{pH}$, ion strength, equilibrium time, and sorbent loading) to iron oxyhydroxide phases is given in Table 4.

In an aqueous systems with $3 \times 10^{-9} \mathrm{M}$ Am(III), Am sorption onto natural hematite is very strong and fast, a 100\% Am sorption is achieved within 2 hours (Table 4). With Eu(III) $2 \times 10^{-4} \mathrm{M}$ in the aqueous systems, the sorption percentage or $\mathrm{K}_{\mathrm{d}}$ of Am onto natural hematite increases with increasing $\mathrm{pH}$ from 2.5 to 5.7; at the same $\mathrm{pH}$ (5.7), the decrease in ion strength $\mathrm{NaNO}_{3}$ from $0.1 \mathrm{M}$ to $0.001 \mathrm{M}$ or the increase in the content of fulvic acid from 0 to $20 \mathrm{mg} / \mathrm{L}$ will significantly increase the Am sorption onto natural hematite (Tao et al. 2006). Although fulvic acid will not be present in tanks, we include this information to demonstrate how strong complexing agents influence Am sorption to oxyhydroxides. At $\mathrm{pH} 5.5$ or $8.0, \mathrm{Am}$ (III) sorbes onto ferrihydrite surfaces as a bidentate corner-sharing species. Bidentate bonding indicates two bonds are formed between the solute and the surface. The implication of this to the PA is that the bond is strong and desorption is less likely to occur than in a monodentate system. Upon heating, ferrihydrite transforms to 
goethite or hematite, the sorbed $\mathrm{Am}$ (III) at $\mathrm{pH} 5$ is released from the sorbed samples during the transformation, but the sorbed Am(III) at $\mathrm{pH} 8$ is partially incorporated into the ferrihydrite transformation products (Stumpf et al. 2006).

Table 4. Americium sorption to iron oxyhydroxide phases

\begin{tabular}{|c|c|c|c|c|c|c|c|c|}
\hline $\begin{array}{l}\text { Radio- } \\
\text { nuclides }\end{array}$ & Sorbents & Solutions & $\begin{array}{l}\text { Ion } \\
\text { strength }\end{array}$ & pH & $\begin{array}{l}K_{d} \\
(m L / g)\end{array}$ & $\begin{array}{l}\text { Sorp- } \\
\text { tion } \\
(\%)\end{array}$ & $\begin{array}{l}\text { Equil } \\
\text { time } \\
\text { (hrs) }\end{array}$ & $\begin{array}{l}\text { Reference / } \\
\text { Description }\end{array}$ \\
\hline \multirow[t]{5}{*}{$\mathrm{Am}$} & $\begin{array}{l}\text { Hematite } \\
\mathrm{V} / \mathrm{m}=400 \\
\mathrm{ml} / \mathrm{g}\end{array}$ & $\begin{array}{l}\mathrm{Am} \\
1.1 \times 10^{-9} \\
\mathrm{M}\end{array}$ & $\begin{array}{l}0.1 \mathrm{M} \\
\mathrm{CaCl}_{2}\end{array}$ & $4-6$ & $\sim 3.96 \times 10^{4}$ & $\sim 99$ & \multirow[t]{5}{*}{$\sim 8$} & \multirow{5}{*}{$\begin{array}{l}\text { Tao et al. (2006) } \\
\text { Without Eu, Am } \\
\text { is completely up- } \\
\text { taken by natural } \\
\text { hematite rapidly. } \\
\text { Am } \mathrm{K}_{\mathrm{d}} \text { onto } \\
\text { hematite increases } \\
\text { with (1) pH } \\
\text { increase, (2) with } \\
\text { fulvic acid (FA) } \\
\text { increase at the } \\
\text { same pH, and (3) } \\
\text { with ion strength } \\
\text { decrease at the } \\
\text { same pH and FA } \\
\text { concentration. } \\
\text { Although FA may } \\
\text { not be present in } \\
\text { tanks, their } \\
\text { interactions with } \\
\text { Am is presented } \\
\text { to demonstrate } \\
\text { how a strong } \\
\text { ligand interferes } \\
\text { with hematite } \\
\text { sorption. }\end{array}$} \\
\hline & $\begin{array}{l}\text { Hematite } \\
\mathrm{V} / \mathrm{m}=400 \\
\mathrm{ml} / \mathrm{g}\end{array}$ & $\begin{array}{l}\text { Am } \\
1.1 \times 10^{-9} \\
\mathrm{M} \\
\mathrm{Eu} \\
2.1 \times 10^{-4} \\
\mathrm{M} \\
\text { No FA }\end{array}$ & $\begin{array}{l}0.1 \mathrm{M} \\
\mathrm{NaNO}_{3}\end{array}$ & 2.5 & 58 & & & \\
\hline & $\begin{array}{l}\text { Hematite } \\
\mathrm{V} / \mathrm{m}=400 \\
\mathrm{ml} / \mathrm{g}\end{array}$ & $\begin{array}{l}\mathrm{Am} \\
1.1 \times 10^{-9} \\
\mathrm{M} \\
\mathrm{Eu} \\
2.1 \times 10^{-4} \\
\mathrm{M}, \text { No FA }\end{array}$ & $\begin{array}{l}0.1 \mathrm{M} \\
\mathrm{NaNO}_{3}\end{array}$ & 5.7 & 246 & & & \\
\hline & $\begin{array}{l}\text { Hematite } \\
\mathrm{V} / \mathrm{m}=400 \\
\mathrm{ml} / \mathrm{g}\end{array}$ & $\begin{array}{l}\mathrm{Am} \\
1.1 \times 10^{-9} \\
\mathrm{M} \\
\mathrm{Eu} \\
2.1 \times 10^{-4} \\
\mathrm{M} \\
\mathrm{FA} \quad 20 \\
\mathrm{mg} / \mathrm{L}\end{array}$ & $\begin{array}{l}0.1 \mathrm{M} \\
\mathrm{NaNO}_{3}\end{array}$ & 5.7 & $2.38 \times 10^{3}$ & & & \\
\hline & $\begin{array}{l}\text { Hematite } \\
\mathrm{V} / \mathrm{m}=400 \\
\mathrm{ml} / \mathrm{g}\end{array}$ & $\begin{array}{l}\text { Am } \\
1.1 \times 10^{-9} \\
\mathrm{M} \\
\mathrm{Eu} \\
2.1 \times 10^{-4} \\
\mathrm{M} \\
\text { No FA }\end{array}$ & $\begin{array}{l}0.01 \mathrm{M} \\
\mathrm{NaNO}_{3}\end{array}$ & 5.7 & $3.6 \times 10^{3}$ & & & \\
\hline $\mathrm{Am}$ & $\begin{array}{l}\text { Ferri- } \\
\text { hydrite } \\
\text { BET } 235 \\
\mathrm{~m}^{2} / \mathrm{g} \\
1.5 \mathrm{~g} / \mathrm{L}\end{array}$ & & & $\sim 5.5$ & $2.67 \times 10^{3}$ & $\sim 80$ & & $\begin{array}{l}\text { Stumpf et al. } \\
(2006) \\
\text { Am sorbs as a } \\
\text { bidentate corner- } \\
\text { sharing species } \\
\text { onto the surface }\end{array}$ \\
\hline
\end{tabular}




\subsection{Technetium}

A summary of the technetium sorption information (adsorption coefficient $\mathrm{K}_{\mathrm{d}}$, adsorption percentage, initial $\mathrm{Pu}$ concentration, $\mathrm{pH}$, ion strength, equilibrium time, and sorbent loading) to iron oxyhydroxide phases is given in Table 5.

The sorption percentages of $\mathrm{TcO}_{4}^{-}$species onto hematite, goethite, ferrihydrite and goethite-coated sand are very low and their $\mathrm{K}_{\mathrm{d}}$ values are near zero in oxidizing conditions (Palmer et al. 1981, Kaplan 2003, Peretyazhko et al. 2009). However, in the aqueous reducing conditions, containing dissolved Fe(II), the Fe(III) oxyhydroxides such as hematite, goethite or ferrihydrite, can adsorb the Fe(II) and then promote the reduction of $\mathrm{Tc}(\mathrm{VII})$ to $\mathrm{Tc}(\mathrm{IV})$ (Peretyazhko et al. 2009). This latter phenomenon increases with increasing $\mathrm{pH}$ and is coincident with a second event of Fe(II) (aq) sorption (Peretyazhko et al. 2009). The reaction is almost instantaneous at $\mathrm{pH}$ 7. Tc(VII) reduction by $\mathrm{Fe}(\mathrm{II})$ is in the order: aqueous $\mathrm{Fe}(\mathrm{II}) \sim$ adsorbed $\mathrm{Fe}(\mathrm{II})$ in phyllosilicate $<<$ structural $\mathrm{Fe}(\mathrm{II})$ in phyllosilicate $<<\mathrm{Fe}(\mathrm{II})$ adsorbed on Fe(III) oxides - hematite and goethite (instantly). The reduced products are sorbed octahedral $\mathrm{TcO}_{2}$ monomers and dimers with $\mathrm{Fe}$ (III) in the second coordination shell, indicating the Tc is incorporated into hematite or goethite structure (Peretyazhko et al. 2009). 
Table 5. Technetium sorption to iron oxyhydroxide phases

\begin{tabular}{|c|c|c|c|c|c|c|c|c|}
\hline $\begin{array}{l}\text { Radio- } \\
\text { nuclides }\end{array}$ & Sorbents & Solution & $\begin{array}{l}\text { Ion } \\
\text { strength }\end{array}$ & pH & $K_{d}(m L / g)$ & $\begin{array}{l}\text { Sorp- } \\
\text { tion } \\
(\%)\end{array}$ & $\begin{array}{l}\text { Equil } \\
\text { time } \\
\text { (hrs) }\end{array}$ & $\begin{array}{l}\text { Reference / } \\
\text { Description }\end{array}$ \\
\hline \multirow[t]{16}{*}{$\mathrm{Tc}$} & \multirow{13}{*}{$\begin{array}{l}\text { Hematite } \\
\text { BET } 9 \\
\mathrm{~m}^{2} / \mathrm{g} \\
4.5 \mathrm{~g} / \mathrm{L}\end{array}$} & \multirow{13}{*}{$\begin{array}{l}\mathrm{Tc} \\
1.03 \times 10^{-5} \\
\mathrm{M}\end{array}$} & \multirow{13}{*}{$\begin{array}{l}\mathrm{Fe}(\mathrm{II}) \\
1.0- \\
1.2 \times 10^{-4} \\
\mathrm{M} \\
0.03 \mathrm{M} \\
\mathrm{Na} \\
\text { acetate }\end{array}$} & 4.0 & 25 & 10 & 24 & \multirow{16}{*}{$\begin{array}{l}\text { Peretyazhko et al. } \\
(2009) \\
\text { Tc } \mathbf{K}_{\mathbf{d}} \text { onto hematite } \\
\text { only is } \sim \mathbf{0 .} \\
\mathrm{Tc}(\mathrm{VII}) \text { reduction by } \\
\mathrm{Fe}(\mathrm{II}) \text { : aqueous } \mathrm{Fe}(\mathrm{II}) \\
\sim \text { adsorbed Fe(II) in } \\
\text { phyllosilicate }<< \\
\text { structural Fe(II) in } \\
\text { phyllosilicate }<< \\
\mathrm{Fe}(\mathrm{II}) \text { adsorbed on } \\
\text { Fe(III) oxides - } \\
\text { hematite and goethite } \\
\text { (instantly). The } \\
\text { reduced products are } \\
\text { sorbed octahedral } \\
\text { TcO } \mathrm{O}_{2} \text { monomers and } \\
\text { dimers with Fe(III) in } \\
\text { 2th coordination shell } \\
\text { - into hematite or } \\
\text { goethite structure. }\end{array}$} \\
\hline & & & & 4.0 & 36 & 14 & 96 & \\
\hline & & & & 4.0 & 36 & 14 & 192 & \\
\hline & & & & 4.5 & 161 & 42 & 24 & \\
\hline & & & & 4.5 & 544 & 71 & 96 & \\
\hline & & & & 4.5 & $\sim 2.2 \times 10^{4}$ & $\sim 99$ & 192 & \\
\hline & & & & 5.0 & $2.25 \times 10^{3}$ & 91 & 24 & \\
\hline & & & & 5.0 & $\sim 2.2 \times 10^{4}$ & $\sim 99$ & 96 & \\
\hline & & & & 5.6 & $\sim 2.2 \times 10^{4}$ & $\sim 99$ & 24 & \\
\hline & & & & 5.8 & $\sim 2.2 \times 10^{4}$ & $\sim 99$ & 24 & \\
\hline & & & & 6.1 & $\sim 2.2 \times 10^{4}$ & $\sim 99$ & 24 & \\
\hline & & & & 6.5 & $\sim 2.2 \times 10^{4}$ & $\sim 99$ & 24 & \\
\hline & & & & 7.0 & $\sim 2.2 \times 10^{4}$ & $\sim 99$ & 24 & \\
\hline & $\begin{array}{l}\text { Hematite } \\
\text { BET } 9 \\
\mathrm{~m}^{2} / \mathrm{g} \\
9 \mathrm{~g} / \mathrm{L}\end{array}$ & $\begin{array}{l}\text { Tc } \\
2.05 \times 10^{-5} \\
\mathrm{M}\end{array}$ & $\begin{array}{l}\mathrm{Fe}(\mathrm{II}) \\
2.3 \times 10^{-4} \\
\mathrm{M}\end{array}$ & 7.0 & $\sim 1.1 \times 10^{4}$ & $\sim 99$ & 24 & \\
\hline & $\begin{array}{l}\text { Goethite } \\
\text { BET } 45 \\
\mathrm{~m}^{2} / \mathrm{g} \\
1.5 \mathrm{~g} / \mathrm{L}\end{array}$ & $\begin{array}{l}\text { Tc } \\
1.03 \times 10^{-5} \\
\mathrm{M}\end{array}$ & $\begin{array}{l}\mathrm{Fe}(\mathrm{II}) \\
1.2 \times 10^{-4} \\
\mathrm{M}\end{array}$ & 7.0 & $\sim 6.6 \times 10^{4}$ & $\sim 99$ & 24 & \\
\hline & $\begin{array}{l}\text { Goethite } \\
3.0 \mathrm{~g} / \mathrm{L}\end{array}$ & $\begin{array}{l}\text { Tc } \\
2.05 \times 10^{-5} \\
\mathrm{M}\end{array}$ & $\begin{array}{l}\mathrm{Fe}(\mathrm{II}) \\
2.3 \times 10^{-4} \\
\mathrm{M}\end{array}$ & 7.0 & $\sim 3.3 \times 10^{4}$ & $\sim 99$ & 24 & \\
\hline \multirow[t]{8}{*}{$\mathrm{Tc}$} & \multirow{4}{*}{$\begin{array}{l}\text { Sediment } \\
\text { with } \\
\mathrm{Fe}_{2} \mathrm{O}_{3} \\
0.01 \%\end{array}$} & \multirow{4}{*}{$\begin{array}{l}\mathrm{TcO}_{4} \\
\text { stock }\end{array}$} & \multirow{4}{*}{$\begin{array}{l}0.01 \mathrm{M} \\
\mathrm{CaCl}_{2}\end{array}$} & 3.2 & 0.3 & & \multirow[t]{4}{*}{168} & \multirow{8}{*}{$\begin{array}{l}\text { Kaplan (2003) } \\
\mathrm{K}_{\mathrm{d}} \text { of } \mathrm{TcO}_{4}{ }^{-} \text {onto iron } \\
\text { oxide-coated sediment } \\
\text { is nearly zero. }\end{array}$} \\
\hline & & & & 4.2 & 0.2 & & & \\
\hline & & & & 6.1 & 0.0 & & & \\
\hline & & & & 6.8 & 0.1 & & & \\
\hline & \multirow{4}{*}{$\begin{array}{l}\text { Sediment } \\
\text { with } \\
\mathrm{Fe}_{2} \mathrm{O}_{3} \\
0.30 \%\end{array}$} & \multirow{4}{*}{$\begin{array}{l}\mathrm{TcO}_{4} \\
\text { stock }\end{array}$} & \multirow{4}{*}{$\begin{array}{l}0.01 \mathrm{M} \\
\mathrm{CaCl}_{2}\end{array}$} & 3.2 & $\sim 0$ & & \multirow[t]{4}{*}{168} & \\
\hline & & & & 4.2 & $\sim 0$ & & & \\
\hline & & & & 7.8 & $\sim 0$ & & & \\
\hline & & & & 8.8 & $\sim 0$ & & & \\
\hline \multirow[t]{2}{*}{ Tc } & Hematite & $\begin{array}{l}\mathrm{TcO}_{4} \\
\text { stock }\end{array}$ & $\begin{array}{l}0.1 \mathrm{M} \\
\mathrm{NaCl}\end{array}$ & $\begin{array}{l}4.1- \\
9.1\end{array}$ & $5.4 \pm 1.2$ & & 504 & \multirow{2}{*}{$\begin{array}{l}\text { Palmer and Meyer } \\
(1981) K_{d} \text { of Tc onto } \\
\text { hematite and } \\
\text { magnetite are very low }\end{array}$} \\
\hline & Magnetite & $\begin{array}{l}\mathrm{TcO}_{4} \\
\text { stock }\end{array}$ & $\begin{array}{l}0.1 \mathrm{M} \\
\mathrm{NaCl}\end{array}$ & $\begin{array}{l}4.3- \\
9.3\end{array}$ & $0.8 \pm 0.8$ & & 504 & \\
\hline
\end{tabular}




\subsection{Conclusions}

The objective of this report was to conduct a literature review to determine whether $\mathrm{Pu}, \mathrm{U}$, $\mathrm{Np}$, Am and Tc would sorb to corrosion products on tank liners after the tank was filled with reducing grout (cementitious material containing slag to promote reducing conditions). There were no studies in the literature specifically designed to simulate SRS conditions of interest; i.e., sorption to corrosion products of these radionuclides in the presence of reducing grout. One of the key ancillary parameters controlling sorption of these parameters is $\mathrm{pH}$; this is especially true of $\mathrm{Pu}$ and $\mathrm{U}$. A grouted tank pore water may have a $\mathrm{pH}>12$ and is expected to maintain that $\mathrm{pH}$ for thousands of years. All literature sorption experiments were performed in $\mathrm{pH}<10.5$ systems. Consequently some extrapolation is involved to predict what would happen in a cementitious - corrosion product environment of $\mathrm{pH}>12$. Furthermore, few studies were found to investigate the radionuclides sorption under reducing conditions. In this document, information is tabulated about trends on how radionuclide sorbed with respect to ancillary parameters, such as $\mathrm{pH}$, redox, radionuclide initial concentration, and solid phases. Based on the collected information, conclusions were then drawn to determine if conservative assumptions were made in existing PAs by not permitting $\mathrm{Pu}, \mathrm{U}, \mathrm{Np}, \mathrm{Am}$ and $\mathrm{Tc}$ to sorb to corrosion products on tank liners.

It is likely that tank liner corrosion products would significantly sorb Pu. Based on the literature review, $\mathrm{Pu}$ tended to have increased sorption with increasing $\mathrm{pH}$ between $\mathrm{pH} 3$ and 10. At $\mathrm{pH} \mathrm{10,} \mathrm{Pu} \mathrm{consists} \mathrm{of} \mathrm{carbonate} \mathrm{and/or} \mathrm{hydroxide} \mathrm{complexes.} \mathrm{It} \mathrm{appears} \mathrm{that}$ the iron oxyhydroxide solid phases out compete these complexes in the aqueous phase for the $\mathrm{Pu}$ to promote $\mathrm{Pu}$ sorption; however, the carbonate alkalinity of $>100 \mathrm{meq} / \mathrm{L}$ would decrease the Pu sorption onto goethite ( $\alpha-\mathrm{FeOOH})$ (Sanchez et al. 1985).

It is unlikely that tank liner corrosion products would retain much uranyl, $\mathrm{UO}_{2}{ }^{2+}, \mathrm{U}$ in the oxidized state. Unlike Pu-hydroxy/carbonate complexes, it appears that uranyl forms complexes at higher $\mathrm{pH}$ values that are resistant to sorption by Fe-oxyhydroxides. Several studies conducted at $\mathrm{pH} 8$ to 10 demonstrated that uranyl sorption decreased compared to lower $\mathrm{pH}$ systems. However, tank grout will create reducing conditions that will promote the reduction of $\mathrm{UO}_{2}{ }^{2+}$ to $\mathrm{U}(\mathrm{IV})$ and by virtue of its tetra-valence, much greater total $U$ sorption to corrosion products would be expected under reducing conditions. Information is lacking on how U(IV) would sorb to corrosion products at high $\mathrm{pH}$; this is a specific area where experimental data may be especially useful.

Due to its higher stable oxidation state $\mathrm{Np}$ as neptunyl, $\left(\mathrm{Np}(\mathrm{V}), \mathrm{NpO}_{2}^{+}\right)$not surprisingly sorbs appreciably less than $\mathrm{Pu}(\mathrm{IV})$ to iron oxyhydroxides. As the $\mathrm{pH}$ increased between 5 and 10 the $\mathrm{K}_{\mathrm{d}}$ values of neptunyl increased significantly. Additionally, there was no experimental data to indicate that the $\mathrm{Np} \mathrm{K}_{\mathrm{d}}$ values declined at higher $\mathrm{pH}$ values as was observed with uranyl due to carbonate complexes; however, some modeling work indicated the decreased adsorption of $\mathrm{Np}$ at higher $\mathrm{pH}$ (Wang and Anderko, 2001). Tank grout may promote reducing conditions, which may promote reduction of $\mathrm{Np}(\mathrm{V})$ to $\mathrm{Np}(\mathrm{IV})$ and therefore greater sorption to corrosion products. Information is lacking on how $\mathrm{Np}(\mathrm{IV})$ would sorb to corrosion products at high $\mathrm{pH}$ values. 
Americium sorbs strongly at high $\mathrm{pH}$ values. There was an exceptionally strong $\mathrm{pH}$ dependence, as sorption $\mathrm{K}_{\mathrm{d}}$ values increased from double digits to four or five digits as the $\mathrm{pH}$ increased from 3 to $>8$. Americium is not a redox sensitive element and therefore the $\mathrm{K}_{\mathrm{d}}$ values would be approximately the same under reducing and older grout that has become oxidized.

Pertechnetate, $\mathrm{TcO}_{4}{ }^{-}$, would not be retained by corrosion products due to surface charge repulsion of the Fe-oxyhydroxide at high $\mathrm{pH}$ and high competing anion concentrations. However, under reducing conditions, the $\mathrm{TcO}_{4}{ }^{-}$would readily convert to $\mathrm{Tc}(\mathrm{IV})$ and again, the tetravalent cation, Tc(IV), would be expected to sorb strongly under reducing conditions to the Fe-oxyhydroxides at high $\mathrm{pH}$ values. We are not aware of any Tc(IV) sorption experiments conducted at elevated $\mathrm{pH}$ values with Fe oxyhydroxides.

The literature review provided insight into the sorption behavior of the radionuclides under oxidizing conditions. Namely, under oxidizing tank conditions, Tc and U sorption to corrosion products is unlikely, whereas significant amount of $\mathrm{Pu}, \mathrm{Am}$, and to a lesser extent $\mathrm{Np}$ sorption will likely occur. There was little information about sorption (except $\mathrm{Pu}(\mathrm{IV})$ ) behavior of these radionuclides under reducing conditions. Reducing conditions are expected to exist initially at the bottom of the tanks because about $8 \mathrm{~m}$ of reducing grout will be placed in the tank residual radionuclides (tank heel). This is of particular interest because $\mathrm{Tc}, \mathrm{Np}$, and $\mathrm{U}$ are likely to reduce to stronger sorbing forms, tetravalent forms. It is very possible that these tetravalent radionuclides would adsorb to corrosion products or simply precipitate in solution. Based on first principles of geochemistry (Sposito, 1984) and expected speciation of high pH geochemistry of cement leachate (Wang et al. 2009) it is expected that tetravalent metals would indeed sorb to these corrosion products; however testing under site specific conditions are necessary to confirm this expectation.

The present PA does not include any sorption to corrosion products in its conceptual geochemical model. Based on this literature review, it is a conservative assumption in the present $\mathrm{PA}$ not to include $\mathrm{Pu}, \mathrm{Am}$, and $\mathrm{Np}$ sorption to corrosion products. It is a conservative assumption in the present PA not to include Tc and $U$ sorption during the period that the tanks are reduced (the first two aging stages); however laboratory information is necessary to confirm this expectation. It is reasonable for the PA to omit Tc and U sorption during oxidizing conditions (older grout).

\subsection{References}

Aamrani, S.E., Giménez, J., Rovira, M., Seco, F., Grive, M., Bruno, J., Duro, L., and De Pablo, J., A spectroscopic study of uranium (VI) interaction with magnetite. Applied Surface Sci. 2007, 253, 8794-8797.

Bargar, J.R., Reitmeyer, R., Lenhart, J.J., and Davis, J.A., Characterization of U(VI)carbonate ternary complexes on hematite: EXAFS and electrophoretic mobility measurements. Geochim Cosmochim. Acta 2000, 64, 2737-2749. 
Carbol, P. and Engkvist, I., Compilation of radionuclide sorption coeffi cients for performance assessment. SKB rapport R-97-13, Swedish Nuclear Fuel and Waste Management Co, 1997.

Duff, M.C., and Amrhein, C., Uranium(VI) sorption on goethite and soil in carbonate solutions. Soil Sci. Soc. Am. J. 1996, 60, 1393-1400.

Duff, M.C., Coughlin, J.U., and Hunter, D.B., Uranium co-precipitation with iron oxide minerals. Geochim Cosmochim. Acta 2002, 66, 3533-3547.

Duro, L., Aamrani, S.E., Rovira, M., De Pablo, J., and Bruno, J., Study of the interaction between U(VI) and the anoxic corrosion products of carbon steel. Applied Geochem. 2008, 23, 1094-1100.

Ferris, F.G., Hallberg, R.O., Lyvén, B., and Pedersen, K., Retention of strontium, cesium, lead and uranium by bacteria iron oxides from a subterranean environment. Applied Geochem. 2000, 15, 1035-1042.

Girvin, D.C., Ames, L.L., Schwab, A.P., and McGarrah, J.E., Neptunium sorption on synthetic amorphous iron oxyhydroxide. J. Colloid and Interface Sci. 1991, 141, 6778.

Hiemstra, T., Van Riemsdijk, W.H., Rossberg, A., and Ulrich, K.U., A surface structural model for ferrihydrite II: Adsorption of uranyl and carbonate. Geochim Cosmochim. Acta 2009, 73, 4437-4451.

Hixon, A. E. Hu, Y. Kaplan, D.I., Kukkadapu, R. K., Nitsche, H., Qafoku, O., and Powell, B. A., Influence of iron redox transformations on plutonium sorption to sediments. Radiochimica Acta 2010, 98, 685-692.

Hsi, C.K.D., and Langmuir, D., Adsorption of uranyl onto ferric oxyhydroxides: Application of the surface complexation site-binding model. Geochim Cosmochim. Acta 1985, 49, 1931-1941.

Jain, A., Rawal, N., Kumar, S., Tomar, B.S., Manchanda, V.K., and Ramanathan, S., Effect of humic acid on sorption of neptunium on hematite colloids. Radiochimica Acta 2007, 95, 501-506.

Kaplan D.I., Powell, B.A., Gumapas, L., Coates, J.T., Fjeld, R.A., and Diprete, D.P., Influence of $\mathrm{pH}$ on plutonium desorption/solubilization from sediment. Environ. Sci. Technol. 2006, 40, 5937-5942.

Kaplan, D.I., Influence of surface charge of a Fe-oxide and an organic matter dominated soil on iodide and pertechnetate sorption. Radiochim. Acta 2003, 91, 173-178.

Kersting, A.B., Zhao, P.H., Zavarin, M., Sylwester, E.R., Allen, P.G., and Williams, R.W., Sorption of $\mathrm{Pu}(\mathrm{V})$ on Mineral Colloids. In Colloid-facilitated transport of lowsolubility radionuclides: A field, experimental, and modeling investigation. (Ed. Kersting, A.B., and Reimus, P.W.), UCRL-ID-149688, Lawrence Livermore National Laboratory, 2003, 67-87.

Liger, E., Charlet, L., and Van Cappellen, P., Surface catalysis of uranium(VI) reduction by iron(II). Geochim Cosmochim. Acta 1999, 63, 2939-2955.

Lu, N., Triay, I.R., Cotter, C.R., Kitten, H.D., and Bentley, J., Reversibility of Sorption of Plutonium-239 onto Colloids of Hematite, Goethite, Smectite, and Silica. LA-UR-983057, Los Alamos National Laboratory, 1998.

Lu, N., Reimus, P.W., Parker, G.R., Conca, J.L., and Triay, I.R., Sorption kinetics and impact of temperature, ionic strength and colloid concentration on the adsorption of plutonium-239 by inorganic colloids. Radiochimica Acta 2003, 91, 713-720. 
Mahoney, J.J., Cadle, S.A., and R.T., Jakubowski, Uranyl sorption onto hydrous ferric oxide-A re-evaluation for the diffuse layer model database. Environ. Sci. Technol. 2008, 43, 9260-9266.

Missana, T., García-Gutiérrez, M., and Maffiotte, C., Experimental and modeling study of the uranium(VI) sorption on goethite. J. Colloid Interface Sci. 2003, 260, 291-301.

Moyes, L.N., Parkman, R.H., Charnock, J.M., Vaughan, D.J., Livens, F.R., Hughes, C.R., and Braithwaite, A., Uranium uptake from aqueous solution by interaction with goethite, lepidocrocite, muscovite and mackinawite: Am X-ray absorption spectroscopy study. Environ. Sci. Technol. 2000, 34, 1062-1068.

Nico, P.S., Steward, B.D., and Fendorf, S., Incorporation of oxidized uranium into Fe (Hydr)oxides during Fe(II) catalyzed remineralization. Environ. Sci. Technol. 2009, 43, 7391-7396.

Palmer, D.A., and Meyer, R.E., Sorption of technetium on selected inorganic ionexchange materials and on a range of naturally occurring minerals under oxic conditions. J. Inorg. Nucl. Chem. 1981, 43, 2979-2984.

Payne, T.E., Brendler, V., Comarmond, M.J., and Nebelung, C., Assessment of surface area normalization for interpreting distribution coefficient $\left(\mathrm{K}_{\mathrm{d}}\right)$ for uranium sorption. $J$. Environ. Radioactivity 2011, 102, 888-895.

Payne, T.E., Uranium(VI) interaction with mineral surfaces: Controlling factors and surface complexation modeling, Ph.D. Dissertation, University of New South Wales, 1999.

Payne, T.E., Lumpkin, G.R., and Waite, T.D., Uranium ${ }^{\mathrm{VI}}$ sorption on model minerals. In Sorption of Metals by Geomedia (Ed. E.A. Jenne), 1998, 75-97.

Peretyazhko, T., Zachara, J.M., Heald, S.M., Jeon, B.H., Kukkadapu, R.K., Liu, C., Moore, D., and Resch, C.T., Heterogeneous reduction if Tc(VII) by Fe(II) at the solidwater interface. Geochim. Cosmochim. Acta 2009, 72, 1521-1539.

Powell, B. A., Fjeld, R. A., Kaplan, D. I., Coates, J. T., and Serkiz, S. M., Pu(V)O ${ }^{2+}$ sorption and reduction by synthetic hematite and goethite. Environ. Sci. Technol. 2005, 39, 2107-2114.

Powell, B. A., Fjeld, R. A., Kaplan, D. I., Coates, J. T., and Serkiz, S. M., Pu(V)O ${ }^{2+}$ Sorption and reduction by synthetic magnetite $\left(\mathrm{Fe}_{3} \mathrm{O}_{4}\right)$. Environ. Sci. Technol. 2004, 38, 6016-6024.

Reich, T., Moll, H., Arnold, T., Denecke, M.A., Herring C., Geipel, G., Bernard G., Nitsche, H., Allen, P.G., Bucher, J.J., Edelstein, N.M., and Shuh, D.K., An EXAFS study of uranium (VI) sorption onto silica gel and ferrihydrite. J. Electron Spect. Rel. Phenom. 1998, 96, 237-243.

Romanchuk, A. Y., Kalmykov, S. N., and Aliev, R. A., Plutonium sorption onto hematite colloids at femto-and nanomolar concentrations. Radiochimica Acta 2011, 99, 137 144.

Rossberg A., Ulrich, K.U., Weiss, S., Tsushima, S., Hiemstra, T., and Scheinost, A.C., Identification of uranyl surface complexes on ferrihydrite: Advanced EXAFS data analysis and CD-MUSIC modeling. Environ. Sci. Technol. 2009, 43, 1400-1406.

Rovira, M., Aamrani, S.E., Duro, L., Giménez, J., De Pablo, J., and Bruno, J., Interaction of uranium with in situ anoxically generated magnetite on steel. J. Hazard. Mat. 2007, 147, 726-731. 
Runde, W., Conradson, S. D., Efurd, D. W., Lu, N., VanPelt, C. E., and Tait, C. D., Solubility and sorption of redox-sensitive radionuclides $(\mathrm{Np}, \mathrm{Pu})$ in $\mathrm{J}-13$ water from the Yucca Mountain Site: Comparison between experiment and theory. Appl. Geochem. 2002, 17, 837-853.

Sanchez, A. L., Murray, J. W., and Sibley, T. H., The sorption of plutonium IV and V on goethite. Geochim. Cosmochim. Acta 1985, 49, 2297.

Sherman, D.M., Peacock, C.L., and Hubbard, C.G., Surface complexation of U(VI) on goethite $(\alpha-\mathrm{FeOOH})$. Geochim. Cosmochim. Acta 2008, 72, 298-310.

Sposito, G., The surface chemistry of soils. New York, NY, Oxford University Press, 1984.

Stewart, B.D., Mayes, M.A., and Fendorf, S., Impact of uranyl-calcium-carbonate complexes on uranium(VI) sorption to synthetic and natural sediment. Environ. Sci. Technol. 2010, 44, 928-934.

Stewart, B.D., Amos, R.T., Nico, P.S. and Fendorf, S., Influence of uranyl speciation and iron oxides on uranium biogeochemical redox reaction. Geomicrobiol. J. 2011, 28, 444-456.

Stumpf, S., Dardenne, K., Hennig, C., Foerstendorf, H., Klenze, R., and Fanghänel, T., Sorption of $\mathrm{Am}(\mathrm{III})$ onto 6-line-ferrihydrite and its alteration products: Investigation by EXAFS. Environ. Sci. Technol. 2006, 40, 3522-3528.

Tao, Z.Y., Chu, T.W., Li, W.J., Du, J.Z., Dai, X.X., and Gu, Y.J., Cation sorption of $\mathrm{NpO}_{2}{ }^{+}, \mathrm{UO}_{2}{ }^{2+}, \mathrm{Zn}^{2+}, \mathrm{Sr}^{2+}, \mathrm{Yb}^{3+}$, and $\mathrm{Am}^{3+}$ onto oxides of $\mathrm{Al}, \mathrm{Si}$, and $\mathrm{Fe}$ from aqueous solution: ionic strength effect. Colloids and Surface Sci. A: Physicochem. Eng. Aspects 2004, 242, 39-45.

Tao, Z.Y., Li, W.J., Zhang, F.M., and Han, J., Sorption of Am(III) on red earth and natural hematite. J. Radioanal. Nucl. Chem. 2006, 268, 563-568.

Waite, T.D., Davis, J.A., Payne, T.E., Waychunas, G.A., and Xu, N., Uranium(VI) sorption to ferrihydrite: Application of a surface complexation model. Geochim. Cosmochim. Acta 1994, 58, 5465-5478.

Wang, P.M., and Anderko, A. Thermodynamic modeling of the adsorption of radionuclides on selected minerals. I: Cations. Ind. Eng. Chem. Res. 2001, 40, 44284443.

Wang, L., E. Martens, D. Jacques, P. Decanniere, J. Berry, D. Mallants. Review of sorption values for the cementitious near field of a near surface radioactive waste disposal facility. Mol, Brussels, ONDRAF/NIRAS, 2009.

Wiersma, B.J., and Subramanian, K.H., Corrosion testing of Carbon Steel in Acid Cleaning Solutions. WSRC-TR-2002-00427, Washington Savannah River Company, Aiken, SC, 2002.

Zeng, H., Singh, A., Basak, S., Ulrich, K.U., Sahu, M., Biswas, P., Catalano, J.G., and Giammar, D.E., Nanoscale size effects on uranium(VI) sorption to hematite. Environ. Sci. Technol. 2009, 43, 1373-1378. 


\section{Distribution:}

P. M. Almond, 773-43A - Rm. 227

A. B. Barnes, 999-W - Rm.336

H. H. Burns, 773-41A - Rm.214

B. T. Butcher, 773-43A - Rm.212

L. B. Collard, 773-43A - Rm.207

D. A. Crowley, 773-43A - Rm.216

S. D. Fink, 773-A - Rm.112

G. P. Flach, 773-42A - Rm.211

B. J. Giddings, 786-5A - Rm.2

J. C. Griffin, 773-A - Rm. A-202

C. C. Herman, 999-W - Rm. 344

R. A. Hiergesell, 773-43A - Rm.218

G. K. Humphries, 705-3C - Rm.206

P. R. Jackson, 703-46A - Rm. 223

D. I. Kaplan, 773-43A - Rm.215

D. Li, 999-W - Rm.336

S. L. Marra, 773-A - Rm. A-230

J. J. Mayer, 773-42A - Rm. 242

A. M. Murray, 773-A, Rm. A-229

F. M. Pennebaker, 773-42A - Rm.146

S. H. Reboul, 773-A, Rm. B-132

K. A. Roberts, 773-43A - Rm.225

K. H. Rosenberger, 705-1C - Rm.33b

F. G. Smith, III 773-42A - Rm.178

K. H. Subramanian, 766-H - Rm.2204

(1 file copy \& 1 electronic copy), 773-43A - Rm.213 